\title{
READING RUINS A TRANSTEXTUAL APPROACH TO THE HANNA ROUNDHOUSE
}

\author{
BY \\ CHARLES C. MOORHOUSE
}

A thesis submitted to the Faculty of Graduate and Postdoctoral Affairs in partial fulfillment of the requirements for the degree of

\author{
Master of Architecture \\ in \\ Architecture
}

Carleton University

Ottawa, Ontario, Canada

(C) 2014

Charles C. Moorhouse 


\begin{abstract}
Reading Ruins: A Transtextual Approach to the Hanna Roundhouse looks at the relationships between 'texts' in adaptive reuse. Transtextuality, which is based on the literary analysis of Gérard Genette, is explored in regards to the architectural relationships between the new, old and forgotten in built form. This thesis abducts and explains transtextuality in regards to architecture and then applies it as a design process in the adaptive reuse of the Hanna Roundhouse. The Hanna Roundhouse, built in 1913 as part of the Canadian Northern Railway, was abandoned for a significant period until its purchase by the Hanna Roundhouse Society in the Fall of 2013.
\end{abstract}




\section{ACKNOWLEDGEMENTS}

The support of many made this research possible.

First I would like to thank my advisor Federica Goffi for your invaluable guidance, dedication, passion and inspiration.

To Sandra Beaudoin for your wealth of knowledge and passion for the Hanna Roundhouse. Your efforts are an inspiration and give me hope for the Roundhouse's future.

To the Alberta Historical Resources Foundation and the Alberta Lottery Fund for your generous support through the Roger Soderstrom Scholarship.

To my friend and fellow adventurer Lacey Shurmer for your friendship and positive spirit.

And finally to my parents for their unwavering patience, support and generosity. 


\section{TABLE OF CONTENTS}

ABSTRACT ii

ACKNOWLEDGEMENTS

iii

INTRODUCTION

2

PART I: TRANSTEXTUALITY \& ARCHITECTURE

4

RUINS AS RECORDS

5

TRANSTEXTUALITY

6

INTERTEXT

8

PARATEXT

METATEXT

HYPERTEXT

ARCHITEXT

22

FROM READER TO AUTHOR

PART II: THE HANNA ROUNDHOUSE

27

PROJECT SITE: HANNA, ALBERTA

HANNA'S RAILWAY HISTORY

ADAPTIVE REUSE PROGRAM

THE ROUNDHOUSE'S EXISTING CONDITION 
A TRANSTEXTUAL APPROACH TO DESIGN

FORM AND PROGRAMMING $\quad 41$

$\begin{array}{ll}\text { THE MUSEUM } & 45\end{array}$

THE CAFÉ AND SHOPS (STALLS 6-10) 51

$\begin{array}{ll}\text { THE THEATRE } & 61\end{array}$

$\begin{array}{ll}\text { THE TURNTABLE AND SITE } & 70\end{array}$

$\begin{array}{ll}\text { MATERIALITY } & 77\end{array}$

$\begin{array}{lr}\text { CONCLUSION } & 81\end{array}$

$\begin{array}{lr}\text { APPENDICES } & 83\end{array}$

ALTERNATIVE CAFÉ DESIGNS $\quad 84$

SITE DOCUMENTATION - HANNA, ALBERTA 85

HANNA CONTEXT \& LANDSCAPE 94

$\begin{array}{lr}\text { PHOTOS - BIG VALLEY, ALBERTA } & 98\end{array}$

$\begin{array}{ll}\text { LIST OF FIGURES } & 101\end{array}$

$\begin{array}{lr}\text { BIBLIOGRAPHY } & 112\end{array}$ 
"I see materials as letters we use to write our poetic thoughts [...]

We work with letters, an alphabet, we write a story"1

-Sverre Fehn 


\section{INTRODUCTION}

Architectural ruins and adaptive reuse projects are sites of intertextual architectural history, some of which may not be visible at first glance. Through ageing and changes in use, architecture becomes a physical, tangible record of time. It is argued here that if we allow ourselves to look close enough, we can read these architectural records 'transtextually', or in other words, in relation to each other.

French literary theorist Gérard Genette coined the term transtextuality. ${ }^{2}$ This neoism is loosely based on Julia Kristeva's definition of intertextuality. For Genette there are five categories of transtextuality and each will be investigated in Part I of my thesis. While Genette explores transtextuality in regards to literary texts, I argue here that it can also be applied in the reading of adaptive reuse projects. Through redefining these terms architecturally, I will present a new paradigm for the analysis and reading of ruins, which I believe, will allow for a richer understanding of composite architectural layers. After projecting onto architecture and redefining the literary terms I will shift from reading architecture transtextually to utilizing this paradigm as an experimental design approach with the hopes of illustrating how a transtextual approach to the adaptive reuse of an industrial ruin can redefine the relationships between the old, new, and forgotten elements in built form.

Part II of my thesis will involve the application of the transtextual design paradigm to the adaptive reuse of an abandoned Canadian Northern Railway Roundhouse in Hanna, Alberta. The Roundhouse and turntable is all that remains of the Canadian Northern Railway yards. Originally built in 1913, the Roundhouse is now in its centennial year. The Roundhouse is an ideal industrial site because it contains layers of historical information that highlight its multiple physical and programmatic transformations. Currently in a 
state of decay, it is in need of being adapted to allow for future use. The physical building has gone through many transformations including an addition (which was demolished in 2012), the raising of the roof for larger locomotives, and various modifications related to programmatic changes after the rail line closed in the 1960's. As of September 2013 the Roundhouse has been under the ownership of the Hanna Roundhouse Society, a not-for profit community organization. Sandra Beaudoin, the president of the society, hopes to reuse it for a railway museum and performance space for which the community is lacking. My design will look at a site master plan overall, as well as the Roundhouse specifically. By analyzing the record of time within the Roundhouse, my new design will both enhance the community's reading of the site as well as intricately stitch the new program and its function within the existing fabric. 
PART I
TRANSTEXTUALITY
\& ARCHITECTURE 


\section{RUINS AS RECORDS}

The desire to identify manifestations of time in ruins is similar to that of archaeology. The ruin is an artifact, which according to archaeologist and author Laurent Olivier is "the place where life's work is inscribed and becomes legible, taking the imprint of what we call time."3 Architecture is a product of humanity and since humanity is ever changing, architecture has to adapt as well, otherwise it risks being demolished or falling into disrepair and eventually ruin. Historical architecture and ruins exist as collages of adaptability and therefore contain transtextual relationships. The original authenticity of the structure becomes a host to physical changes through both natural and man-made interventions. This is because ruins are not static objects. According to Sociologist Alice Mah in her book Industrial Ruination, Community, and Place she states "at any given moment, an industrial ruin appears as a snapshot of time and space within a longer process of ruination." ${ }^{4}$ Olivier echoes this concept when he writes,

there lies recorded within the sequence of physical transformations superimposed upon an object's initial state-through disfigurement, transformation, and deterioration - the memory of a succession of states, each of which had a particular identity and served a particular purpose. ${ }^{5}$

Here Olivier equates architectural changes through time to a process of recording. If architectural ruins (and other historical buildings) act as records, how does one dissect and interpret the embedded information? This will be explored at varying scales, from the whole to the smallest of details. These historical layers will be identified and framed in relation to each other and in relation to time. 


\section{TRANSTEXTUALITY}

The transtextual methodology I propose for interpreting embedded architectural relationships originates in literary theory. Gérard Genette (b. 1930) is a French literary theorist who proposed transtextuality as a framework for analyzing literature. His transtextual contribution to the subject of poetics is a form of structuralism in which he "focuses on relations between texts, the way they reread and rewrite one another." Literary theorists have benefitted from his approach of looking beyond a single text and acknowledging external influences and relationships within any given text. ${ }^{7}$ He defines transtextuality as "all that sets the text in a relationship, whether obvious or concealed, with other texts." For Genette, transtextuality has five categories: intertext, paratext, metatext, hypertext, and architext. While most of the transtextual paradigm can be traced back to Genette, the term intertext was originally coined by literary critic and psychoanalyst Julia Kristeva (b. 1941). Kristeva's definition of intertext, however, is more closely related to Genette's definition of transtextuality than his definition of intertext. Through Genette's five definitions, this paradigm creates a categorization or mapping system for textual relations, which allows us to analyze and understand these connections.

While Genette explores transtextuality in regards to literary texts, I believe a similar approach can be applied in the reading of architectural ruins and adaptive reuse projects. Through redefining the five terms architecturally, I will present a new paradigm for the analysis and reading of ruins and adaptive reuse projects. Since transtextuality is the analysis between two texts, I must begin by defining what is an autonomous literary and architectural text for comparison and reference. A literary text is a single body of written work, distinct from other works and supporting notes, headings, illustrations, etc. What is important to note is that it is in and of itself a single creation. An architectural text is more abstract as it varies according to scale, and therefore can be a whole structure 
or a singular element within it - both of which having a distinct identity or ethos. This broader definition of an architectural text can be applied to transtextuality in two ways. The first way would be to examine a whole and complete structure with both outside and contextual influences (through form, style, etc.). The second way, which is primarily important for the sake of reading architectural ruins and cases of adaptive reuse, would be to examine internal relationships related to coexisting or previous texts that have influenced the current state of the building. This differs from the literary relationships between two distinct texts, and creates the largest obstacle when projecting onto architecture, since architecture is more additive and prone to physical evolution than a literary text. This will be clarified as I define the five terms of transtextuality in relation to architecture. Not only will I define the terms architecturally speaking, but I will also identify issues and solutions that arise in my abduction. ${ }^{9}$ Much like their literary counterparts, it is important to note that these five terms should not be considered as individual and finite categories since there is often reciprocal or overlapping contact. ${ }^{10}$ 


\section{INTERTEXT}

Intertextuality is not only the first term of transtextuality, but it is also the origin of the terminological paradigm used by Genette. Genette's paradigm is influenced by Kristeva's definition of intertextuality in her book Desire in Language: A Semiotic Approach to Literature and Art. ${ }^{11}$ Kristeva defines intertext as "the transposition of one or more systems of signs into another." ${ }^{12}$ Clearly Kristeva's intertextual definition relates more to Genette's over-arching transtextual definition as opposed to his intertextual one. Genette's definition of intertextuality, which I will use in my projection onto architecture, is "eidetically and typically as the actual presence of one text within another."13 In literature, this often takes the form of quoting, among others.

Architecturally, it is easy to transcribe the intertextual theory of textual co-presence. In adaptive reuse, for example, intertextuality is inherent in all cases since adaptive reuse is the physical combination of a new and old system. This universality of the co-presence of two texts has the potential to undermine the definition, as it is entirely inclusive. For example, Peter Zumthor's Kolumba Museum in Cologne, Germany, is a visually obvious expression of two co-existing texts. The ruins of the destroyed late-gothic cathedral contrast against the lightness of Zumthor's custom bricks which house the new museum program. While the material construction is in fact intertextual, the overall design goes beyond this by transforming the ruins into something completely different. The Kolumba Museum will be explored in more depth later on, however, this example demonstrates the overlapping of relationships since this example describes an intertext with a transformative relationship and therefore a hypertextual relationship. For the case of this study, I shall reserve the use of intertext for examples of coexistence without transformation. 
There are also cases that are inherently intertextual such as spolia, where one architectural element is reused in a new way and in a new structure. The isolated element is read in the context of the new whole structure, yet knowledge of its origins can be read specifically through the spoiled element. In this way, the new architectural text is explicitly "quoting" another. The spoiled element in most cases predates the new compounded text to which it now belongs. As a result, the intertextual element belongs to a new present text while it specifically looks backwards, having been borrowed from a previous architectural text.

A clear example of intertext and spolia is British architect John Soane's home and museum, Lincoln's Inn Fields 13 in London (1812). The façade contains four capitals, which seem to be purposefully misaligned within the geometry of the façade. This misalignment draws attention to the fact that they are a different element within the whole. What makes these capitals intertextual is that they were spoiled from Westminster Hall in London. Soane worked on the restoration of Westminster Hall where he appropriated the capitals in 1818 and added them to the façade of his home in $1824 .{ }^{14}$ Both the fragmentation and misalignment of the capitals seem to evoke an architectural quoting of Westminster Hall within the newer text of Lincoln's Inn Fields 13. 

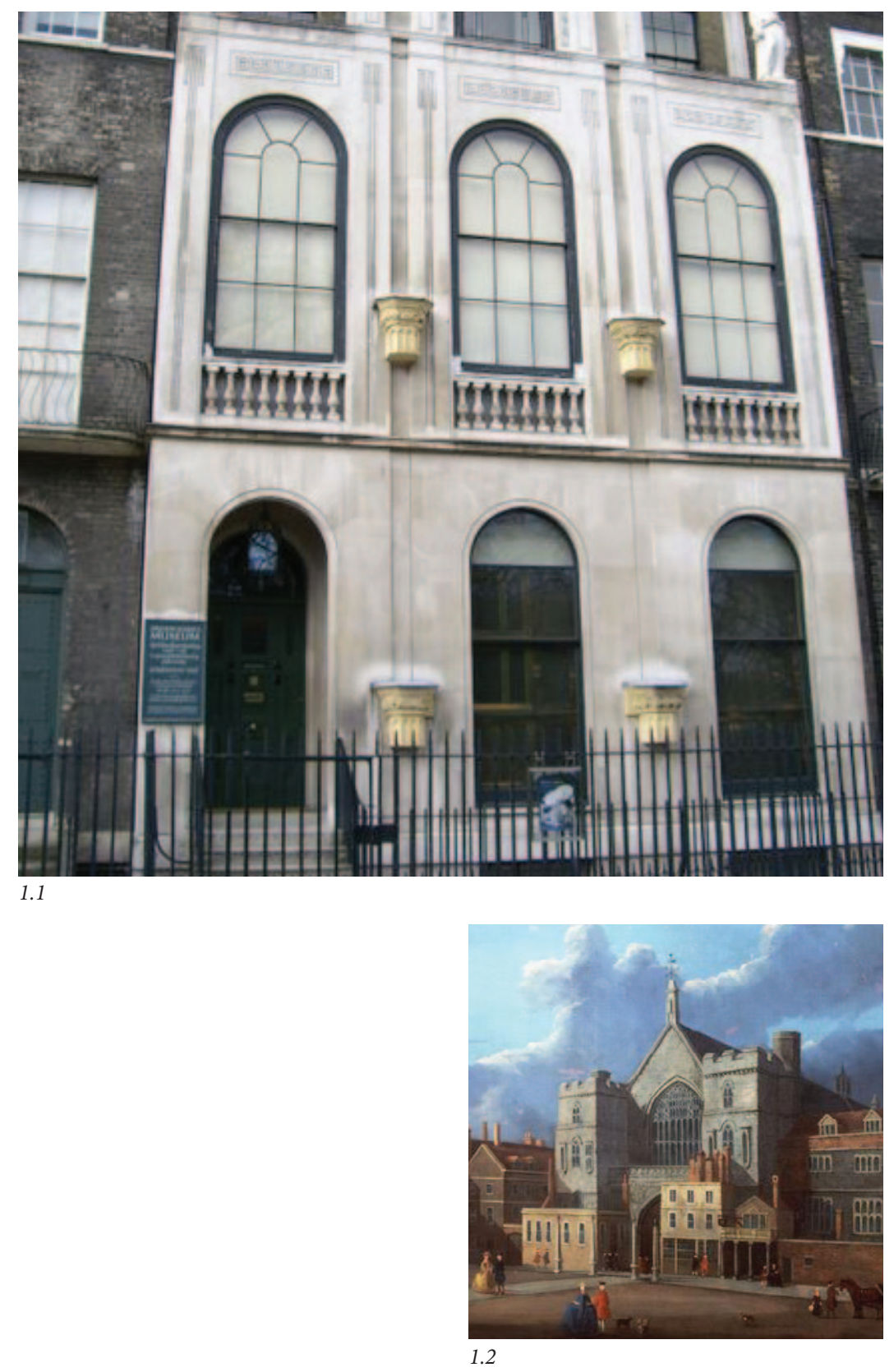


\section{PARATEXT}

Genette dedicates his third book on transtextuality to the exploration of paratext entitled Paratexts: Thresholds of Interpretation. ${ }^{15}$ He defines paratexts as secondary signals that influence the understanding of the primary text. ${ }^{16}$ These secondary signals include "liminal devices and conventions, both within the book (peritext) and outside it (epitext), that mediate the book to the reader: titles and subtitles, pseudonyms, forewords, dedications" as well as illustrations and covers. ${ }^{17}$ According to Philippe Lejeune in Le pacte autobiographique, whom Genette quotes in Paratexts: Thresholds of Interpretation, a paratext is "a fringe of the printed text which in reality controls one's whole reading of the text."18

There are two approaches to projecting paratextuality onto architecture: the first is a more literal correlation, while the second is more abstract. The first includes elements such as titles, authorship (the architect's name attached to the project) and promotional images, among other things, all of which exist within architecture and influence the public's understanding of a project. Take a well-known architect such as Norman Foster or Zaha Hadid. Their names alone conjure images and preconceived notions of their work. For the sake of my study I will be focusing on the second approach, which analyzes physical architectural elements both within and outside of the main building. This second and more abstract approach involves thresholds of understanding. Genette uses the word "threshold" which is interesting as this word has a very particular definition in architecture involving an entrance or point of crossing between spaces. Genette, however, describes it as "more than a boundary or a sealed border, the paratext is, rather, a threshold, [...] that offers the world at large the possibility of either stepping inside or turning back. It is an 'undefined zone."' ${ }^{19}$ While this can take the literal form of a threshold in architecture, it is much broader to include particular elements that 
frame one's experience of the architectural text, or as Genette refers to it, a threshold of understanding.

An example of an architectural paratext is the Roosevelt Park Master Plan in Detroit by Urban Detail LLC and Tadd Heidgerken. The park is situated in front of the abandoned Michigan Central Station. The station was originally built in 1913 by the architectural firm Reed and Stem in association with Warren and Wetmore, the same two firms that designed Grand Central Station in New York City. Michigan Central Station, however, has been abandoned and left to decay since closing in 1988. The station has become a local landmark and an icon of the expansively abandoned city. Started as a community grass roots project, the Roosevelt Park Master Plan leaves the abandoned station alone as a backdrop, but develops the surrounding land into a useable leisure and skate park. The aim of the park is to draw attention to the station in hopes of saving it. ${ }^{20}$ The park represents the community of Detroit's willingness and desire to reclaim what Detroit has lost. It fundamentally changes the context in which the station exists from an abandoned landscape of decline to one of community renewal and organization.

Another example of paratextuality is Richard Meier's Ara Pacis Museum in Rome, Italy. Completed in 2006, this modern museum is located within the historic centre of Rome and houses the Ara Pacis Augustae, a sacrificial altar dating back to 9 B.C. The altar is an existing text, which has been relocated (in 1938) from its original location to the Piazza Augusto Imperatore. When it was relocated it was housed in a new pavilion, which due to decay was replaced by Meier's new museum. ${ }^{21}$ Both Meier's and the previous enclosure act as a threshold, which decontextualizes the altar. The altar is no longer read as a space within the city, but as a museum artifact. This reframing of the Ara Pacis Augustae by Meier's museum is paratextual. 

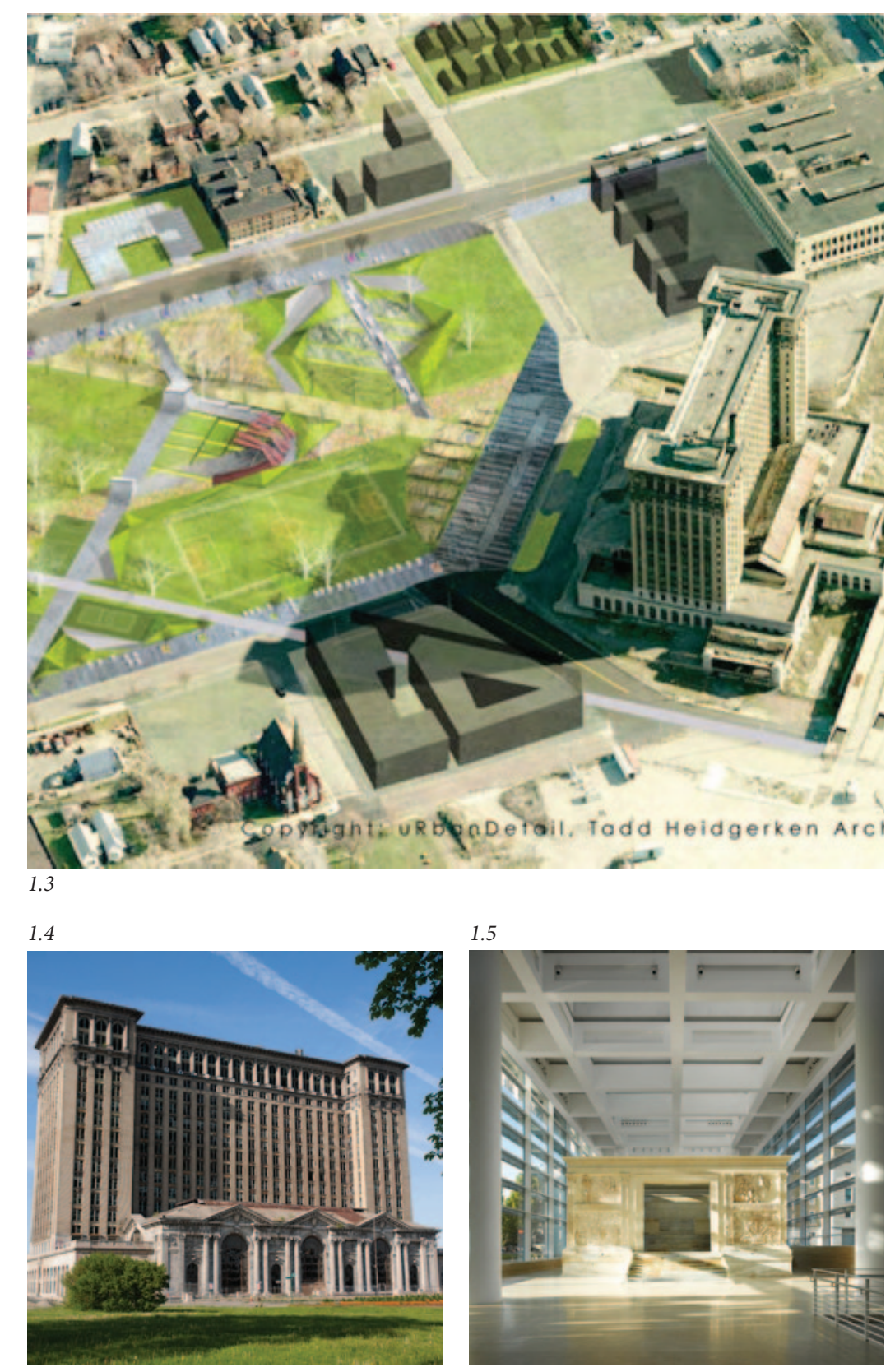

Figures:

1.3 - Roosevelt Park Master Plan, Detroit, by Urban Detail \& Tadd Heidgerken

1.4 - Michigan Central Station ruin in Detroit

1.5 - Ara Pacis, Rome

1.6 - Ara Pacis Museum, Rome by Richard Meier

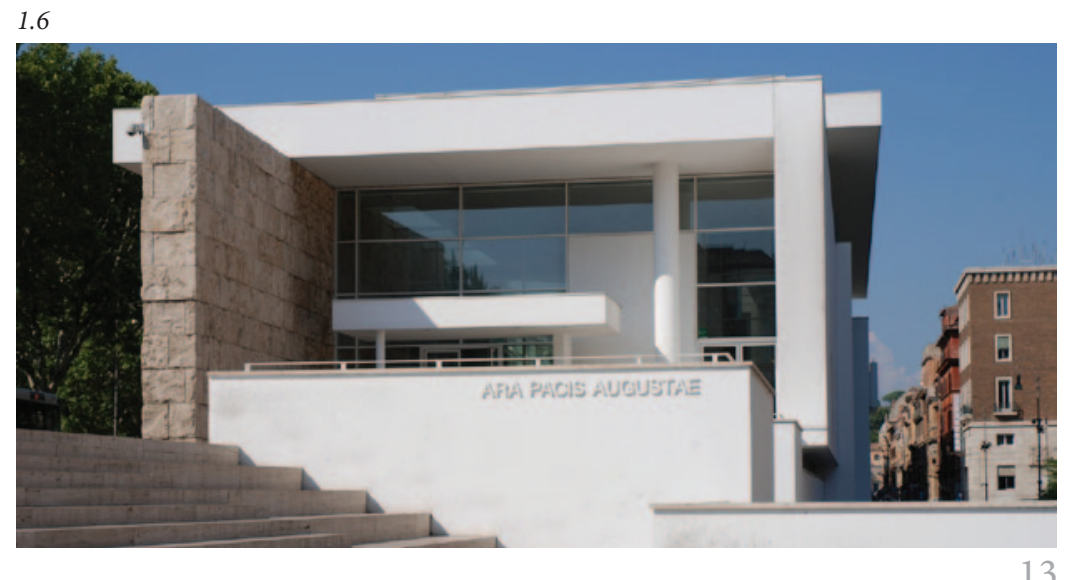




\section{METATEXT}

Metatextuality is more abstract than the previous two definitions. In literature Genette equates this to commentary, however it is a commentary without explicit citations. A commentary with explicit citations would be better defined as an intertext. Nor is a metatext an additive commentary in a republished or later edition by other authors, as these would act as secondary signals and thresholds of understanding of the main text. That would be paratext not metatext. Metatext is a distinct text that comments upon another without explicitly citing it. The relationship is only seen if the reader has knowledge of the text for which the metatext is commenting upon. Genette also describes this act of commentary as "silently evok[ing]" or referencing another text. ${ }^{22}$ As a result, Genette says "all literary critics, for centuries, have been producing metatext without knowing it." ${ }^{23}$ Due to this rather large range Genette does not discuss metatext in the same amount of detail that he describes the other terms. I believe, however, that in the abduction of metatextuality into architecture that metatext plays an important role in the transtextual paradigm.

To me, there are two ways of approaching metatextual relationships in architecture and in literature. The first is using deliberate metatexts and the second is using unintentional metatexts, the latter of which Genette refers to when authors create metatext without their conscious awareness. These unconscious relationships occur because new creations are often not unique; they are manifestations of compounded knowledge and experience. Deliberate metatextuality, on the other hand, is the conscious commentary of another text, either existing or lost.

Precedent studies often lead to direct and indirect influences on new projects, resulting in metatextual references. The Archbishopric Museum by Sverre Fehn in Hamar, Norway, 
is a project rich in transtextual relationships, including metatextuality. The museum is built upon the ruins of a nineteenth-century barn and medieval fortress. The defining element of the design is a bridge, which animates and narrates the space. It is important to note that Sverre Fehn admired the work of Carlo Scarpa, and Fehn's museum notably evokes Carlo Scarpa's Castelvecchio Museum in Verona. ${ }^{24}$ The relationship between the Archbishopric Museum and the Castelvecchio Museum are direct and unambiguous as the two architects often conversed about their ideas. ${ }^{25}$ The two museums were constructed 15 years apart: Castelvecchio between 1956-1964 and the Archbishopric Museum between 1967-1979. In Fehn's museum the most obvious resemblance and metatext is the bridge. Both works contain bridges that weave throughout the existing ruins and provide visitors with an elevated view of the ruins. The bridges of the Archbishopric Museum also show how there can be overlap between the transtextual relationships. Not only is the Archbishopric Museum bridge metatextual in relation to Scarpa's work, but it is also paratextual in relation to the existing ruins. This paratextual relationship is evident in the way the bridges display the ruins as if they are the museum artifacts themselves. The whole of Fehn's project, by transforming a barn and medieval fortress into a museum, is hypertextual - a term that will be defined in more detail later.

Metatextual relationships can also reference the loss of a previous architectural text. Memorials and commemorative monuments comment upon past events and therefore can contain metatextual relationships. The terrorist attacks of September 11, 2001 were a significantly important moment in Western history. This event is inherently linked with the images of the World Trade Centre's twin towers in New York City. Today, the 9/11 Memorial references not just this horrific and traumatic event, but also the architecture of the twin towers, which were a previously existing text. There are specific relationships between the architecture of the memorial and the architecture of the World Trade Centre that can be considered metatextual. For example, the memorial consists of two black 

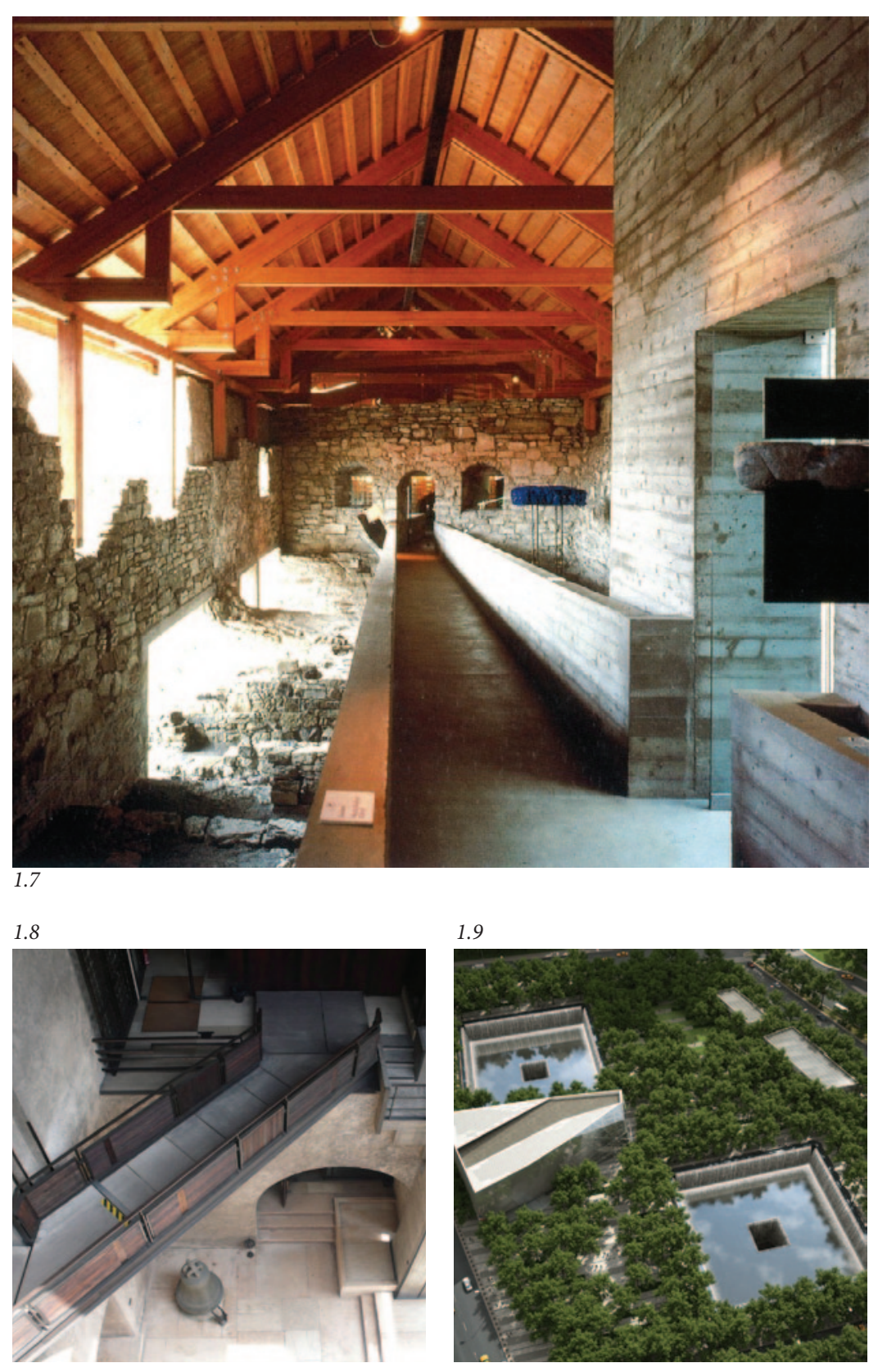

Figures:

1.7 - Archbishopric Museum in Hamar, Norway by Sverre Fehn 1.8 - Castelvecchio, Verona, Italy by Carlo Scarpa

1.9 - 9/11 Memorial \& Museum, New York City, by Michael Arad

1.10 - Tribute in Light, New York City

\subsection{0}

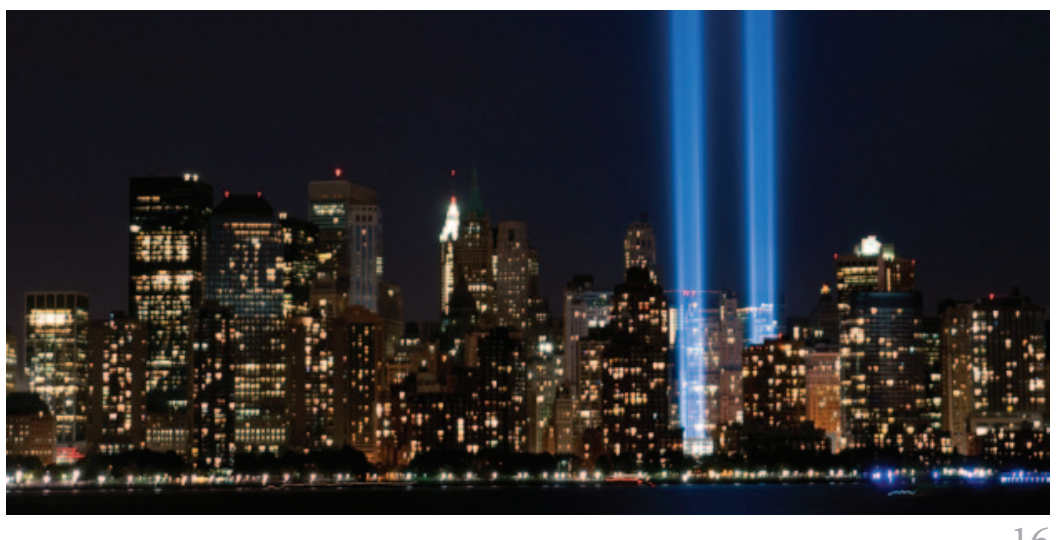


granite-reflecting pools with waterfalls, both positioned within the footprints of the destroyed towers. ${ }^{26}$ These reflecting pools act as voids in the city, marking the territory of what was lost and preventing new development. While the memorial marks the location of the twin towers, the art installation, "Tribute in Light", metatextually references the lost towers in the skyline of New York. The installation is a series of spotlights near ground zero that is recreated on special occasions to commemorate the attack. ${ }^{27}$ The two columns of lights replace the iconic twin towers in the skyline at night.

\section{HYPERTEXT}

Genette's second book on transtextuality, Palimpsests: Literature in the Second Degree, explores hypertextuality. ${ }^{28} \mathrm{~A}$ hypertextual relationship, simply put, is a relationship between a text (hypertext) with a previous text from which it is derived (hypotext). The hypertext is therefore a modification, transformation, elaboration, sequel, superimposition or extension of the hypotext. Genette describes the hypertext as a text that "can be read both for itself and in relation to its hypotext." ${ }^{29}$ Genette highlights the power of hypertextuality's transformative relationship by saying,

The art of "making new things out of old" has the merit, at least, of generating more complex and more savory objects than those that are "made on purpose"; a new function is superimposed upon and interwoven with an older structure, and the dissonance between these two concurrent elements imparts its flavor to the resulting whole. $^{30}$

Architecturally speaking, defining the meaning of a "text" is important for understanding hypertextuality, since hypertextuality deals with a transformation between texts. When does one architectural text become another? This is a difficult question to answer as it often relates to each specific case. Generally a new text is created when the identity or ethos of the previous text is transformed into something new. An alteration of the text is 
inherent in the architectural projection of hypertextuality. The hypertext creates a new identity or ethos for the building, through which the hypotext can be read, even though the identity and ethos of the hypotext may no longer exist. This relationship, at its best, is similar to that of palimpsests. The term palimpsest originates in the middle ages. According to Olivier, "in the Middle Ages, a paucity of parchment often led monks to scratch off what was inscribed on manuscripts so they could write something new in its place. We call these superimposed layers of writing palimpsests." ${ }^{31}$ While the original text shows through, the act of erasure plays an important role in palimpsests as it suggests a hierarchy of importance between texts. The previous text was worth sacrificing for the creation of the new one. Genette explains,

[the] duplicity of the object, in the sphere of textual relations, can be represented by the old analogy of the palimpsest: on the same parchment, one text can become superimposed upon another, which it does not quite conceal but allows to show through. ${ }^{32}$

The term has since become applicable to a broader range of transcription, including architecture. Rodolfo Machado in his article "Old Building as Palimpsest" writes that a remodeled architectural work

can be seen as a text of a special kind that is characterized by the juxtaposition and co-presence of other texts. If an original building is considered as a first discourse that conditions future formal discourses to be inscribed upon it, then remodeling can be conceived of as rewriting. ${ }^{33}$

As previously mentioned, Zumthor's Kolumba Museum in Cologne, Germany is a good example of hypertextuality. This art museum of the Cologne Archdiocese (hypertext) transforms the ruins of the late-gothic Saint Kolumba Church (hypotext), which was destroyed in the Second World War. In maintaining the original plans and by building the new walls out of the old ones, the newly transformed building becomes part of the 
architectural continuum. ${ }^{34}$ The museum is read as a modern yet respectful new text. The ruins, which appear frozen in the new façade, allow the reader to identify moments of the previous text. The ground floor remains an open archaeological site that is navigated by a bridge (perhaps Zumthor is metatextually referencing Scarpa and Fehn) and inside the grounds is a peaceful courtyard, which replaces a lost medieval cemetery. ${ }^{35}$

Another hypertextual example is the High Line in New York City. Not only is it hypertextual, it is also an example of a palimpsest due to the superimposition of a modern park onto an industrial infrastructure. What is clear about this example is the juxtaposition between the hypotext (infrastructure of hard industry) and the hypertext (soft natural park-scape). The construction process of the project presents the most literal representation of a palimpsest. The first step of the construction process was removal, which involved "everything on the structure, including steel rails, gravel ballast, soil, debris and a layer of concrete," as well as built up dirt, vegetation and debris ${ }^{36}$ Prior to the removal of the rails, each rail was identified, labeled, and mapped in order for reuse in the final design. The complete removal of the top level of the High Line was necessary to verify the remaining steel structure as well as install proper drainage and waterproofing. This removal is the first step of a palimpsest, as much (but not all) of the original layers are removed in order to accept a new layer - in this case the hypertext. In the winning proposal by landscape architect James Corner, architecture firm Diller + Scofidio \& Renfo and garden designer Piet Oudolf, they state, "the team retools this industrial conveyance into a post-industrial instrument of leisure, life, and growth. ${ }^{37}$ As illustrated by the architects' goals, you have the palimpsestic change of an industrial artifact into a modern park. In addition you also have embedded in the project the time of natural growth and 
seasons. In the book, Why We Build, British architecture critic Rowan Moore describes the High Line as

a work of different kinds of time. There is the historic time of the old railway, its rise, abandonment, and re-use, its part in the industrial history of New York. There are the lifecycles of the plants and their seasonal changes. ${ }^{38}$

These multiple rhythms of time are expressed simultaneously as one walks through the park. The design qualifies as a hypertext and a palimpsest due to the fact that it is transforming the original structure into something completely new, while at the same time allowing elements from the initial state to show through and remind viewers of the previous life of the building. Moore describes the rails as one of the palimpsestuous elements. He writes, "relics of rails and sleepers are half-buried in the planting and paving. You don't forget what this thing was, but you also know that it is something different." ${ }^{39}$ The rail lines were removed and consciously put back in order to summon or evoke the previous life of the High Line. The detailing of the concrete decking also reinforces this as it dematerializes into the wildness of the planting beds that contain the rails. It is almost as if the planting beds are fragmented memories of the abandoned railway. They materialize and dematerialize as one "remembers" while moving through the park. 

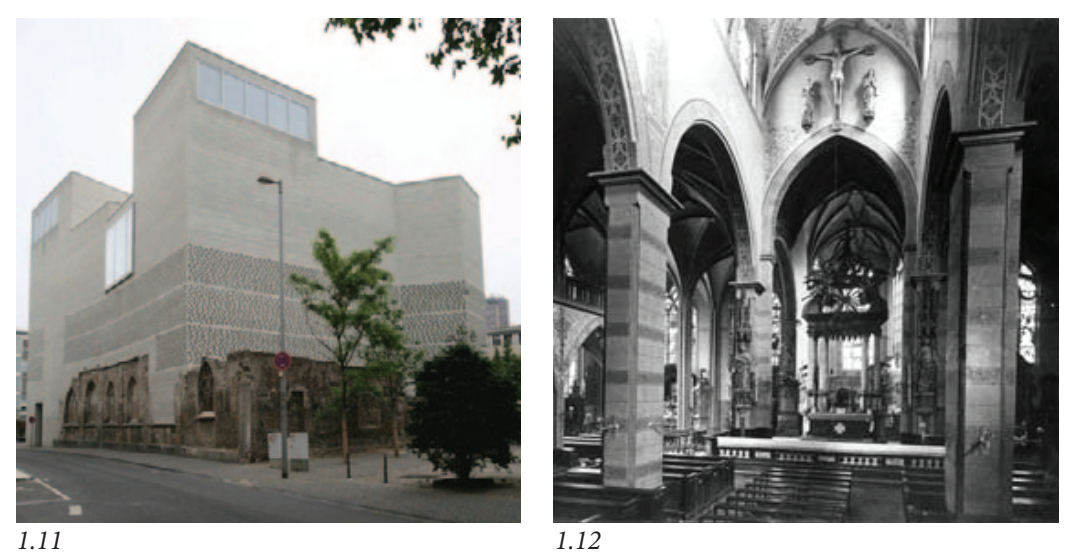

1.12

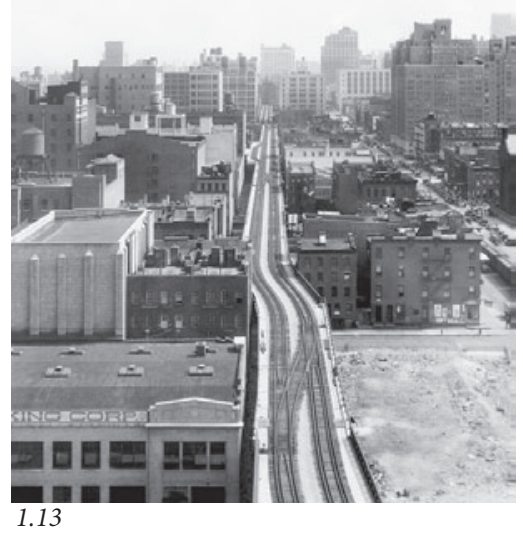

1.14

Figures:

1.11 - Kolumba Museum, Cologne, Germany by Peter Zumthor

1.12 - St. Columba Church, pre-

bombing, Cologne, Germany

1.13 - Original elevated railway, New York City

1.14 - The High Line, New York City by James Corner, Diller Scofidio + Renfro \& Piet Oudolf

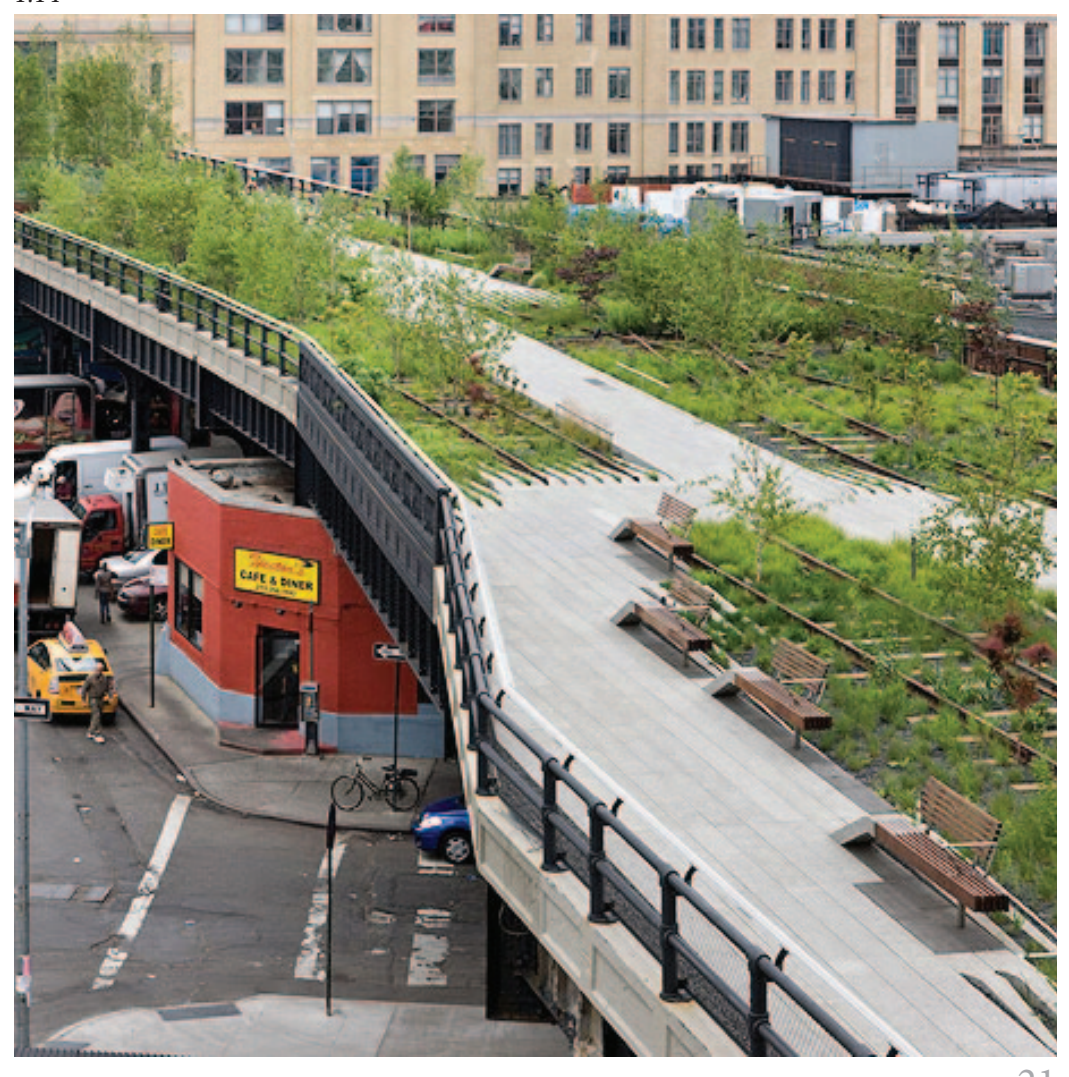




\section{ARCHITEXT}

Genette's final term, architextuality, is the designation of a text to its genre, both in typology (novel, poem, etc.) and style (romance, tragedy, detective, etc.). It is the "most abstract and implicit of the transcendent categories, the relationship of inclusion linking each text to the various kinds of discourse of which it is a representative." 40 The architext is therefore the element that the reader uses in their categorization of the text. This definition projects similarly onto architecture through typology (cathedral, hospital, residential, etc.) and style (baroque, neoclassical, modern, etc.).

Notre-Dame de Paris is a host to several architextual elements. One of the strongest characteristics of its gothic style is the pointed arch. This architextual cue between the pointed arch and the gothic style signals to the users that the categorization of NotreDame is Gothic. While there are many other examples within Notre-Dame that signify its categorization as a gothic cathedral, perhaps the most interesting are the elements introduced by Viollet-le-Duc during his restoration of the cathedral between 1843$1864 .{ }^{41}$ Research and recording was an important part of Viollet-Le-Duc's restorative methodology. His research on the gothic style resulted in an idealized concept composed of numerous gothic architexts. This led Viollet-le-Duc to add architexts to Notre-Dame that belonged to his idealized concept, even if they were foreign to Notre-Dame itself and its history. ${ }^{42}$ This reinforcement of the gothic style through the addition of previously nonexistent architexts includes the gargoyles and work on the central spire. 

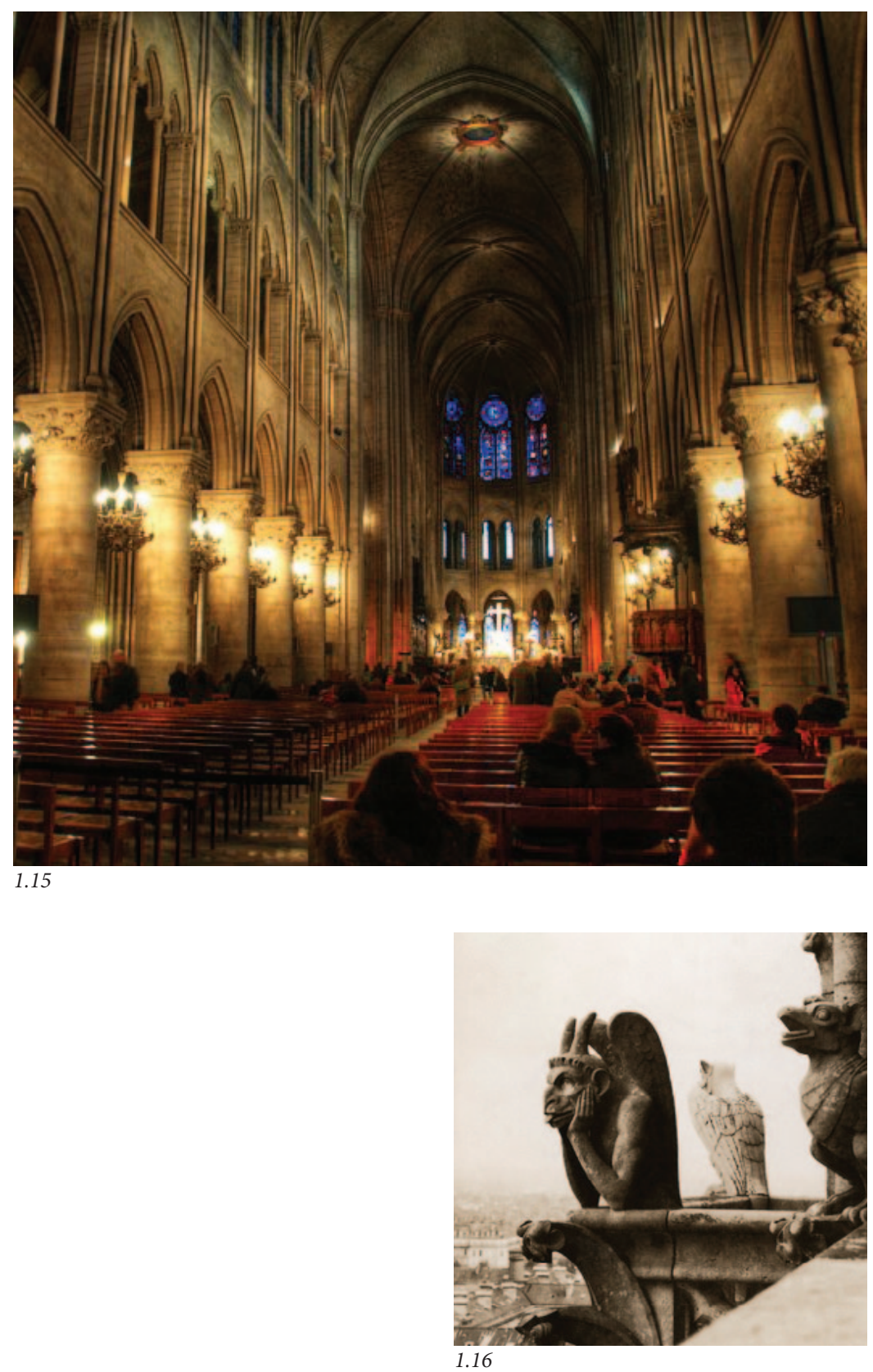

Figures:

1.15 - Interior, of Notre Dame, Paris

1.16 - Le Stryge gargoyle, Notre Dame,

Paris 


\section{FROM READER TO AUTHOR}

Thus far, transtextuality and my abduction of it into architecture have examined how buildings can be read, thereby allowing for a deeper understanding of historical and structural relationships. While the limited sample of cases provided for each type of textual relation are chosen based on my interpretation of the terms, my intention was to offer clear and definitive examples to demonstrate the abduction of transtextuality into the reading of adaptive reuse.

The design project in Part II will shift transtextuality from the relationships read in completed texts to using transtextuality as part of the design process. This role reversal from reader to author will illuminate additional relationships that may not otherwise be legible when reading architectural texts without the explicit knowledge of the architect's (author's) intentions. Through the act of designing I will illustrate how a certain detail can be transtextually explored in multiple ways, and how this will allow the transtextual terms to be compared and contrasted. 


\section{ENDNOTES}

Hill, Jonathan. Weather architecture. London: Routledge, 2012: 272.

Genette, Gérard. Palimpsests: literature in the second degree. Lincoln: University of Nebraska Press, 1997.

Olivier, Laurent. The dark abyss of time: archaeology and memory. Lanham, Md.: AltaMira Press, 2011: 180.

Mah, Alice. Industrial ruination, community, and place: landscapes and legacies of urban decline. Toronto: University of Toronto Press, 2012: 11.

Olivier, Laurent. The dark abyss of time: archaeology and memory. Lanham, Md.: AltaMira Press, 2011: 131.

Genette, Gérard. Palimpsests: literature in the second degree. Lincoln: University of Nebraska Press, 1997: ix.

Entry on Gérard Genette. The Johns Hopkins Guide to Literary Theory and Criticism, 2nd ed. Ed. Michael Groden, Martin Kreiswirth, and Imre Szeman. Baltimore: Johns Hopkins UP, 2004. 43033.

Ibid: 1 .

Abduction coined by Charles Sanders Peirce and used architecturally by Marco Frascari. Frascari, Marco. "'Semiotica ab Edendo," Taste in Architecture." Journal of Architectural Education (1984-) 40, no. 1 (1986):2.

Ibid: 7.

Kristeva, Julia. Desire in language: a semiotic approach to literature and art. New York: Columbia University Press, 1980.

Ibid: 15.

Genette, Gérard. Palimpsests: literature in the second degree. Lincoln: University of Nebraska Press, 1997: 2 .

4 Goffi, Federica. Time matters: Invention and (Re)Imagination in Conservation: invention and (re)imagination in conservation: the unfinished drawing and building of St. Peters, the Vatican. Farnham: Ashgate, 2013: 142.

5 Genette, Gérard. Paratexts: thresholds of interpretation. Cambridge: Cambridge University Press, 1997.

6 Genette, Gérard. Palimpsests: literature in the second degree. Lincoln: University of Nebraska Press, 1997: 3.

Genette, Gérard. Paratexts: thresholds of interpretation. Cambridge: Cambridge University Press, 1997: xviii.

Ibid: 2 .

Ibid: 1 .

Detroit Lives. DVD. Directed by Thalia Mavros. Docurama, 2010.

"Ara Pacis Museum." Richard Meier \& Partners Architects LLP. http://www.richardmeier.com/ www/\#/projects/architecture/location/europe-a-m/italy/1/277/0/ (accessed December 30, 2013). Genette, Gérard. Palimpsests: literature in the second degree. Lincoln: University of Nebraska Press, 1997: 4.

Genette, Gérard. Paratexts: thresholds of interpretation. Cambridge: Cambridge University Press, 1997: xix.

Hill, Jonathan. Weather architecture. London: Routledge, 2012: 277.

Schulz, Christian, and Gennaro Postiglione. Sverre Fehn: works, projects, writings, 1949-1996. New York: Monacelli Press, 1997: 15.

"About the Memorial." 9/11 Memorial. http://www.911memorial.org/about-memorial (accessed March 31, 2014).

“'Tribute in Light' Will Keep Shining, This Year and the Next." City Room Tribute in Light Will Keep Shining This Year and the Next Comments. http://cityroom.blogs.nytimes.com/2010/09/10/ tribute-in-light-will-keep-shining-this-year-and-the-next/?_php=true\&_type=blogs\&_r=0 (accessed March 31, 2014). 

1997.

Ibid: 398 .

Olivier, Laurent. The dark abyss of time: archaeology and memory. Lanham, Md.: AltaMira Press, 2011: 129.

32 Ibid: 398.

33 Machado, Rodolfo. Old Buildings as Palimpsest, in "Progressive Architecture", November, 1976: 46.

34 "Building." KOLUMBA. http://www.kolumba.de/?language=eng\&cat_select=1\&category=14\&artik le $=61 \&$ preview $=($ accessed January 5,2014$)$.

35 Ibid.

36 “Construction." The High Line. http://www.thehighline.org/construction (accessed November 4, 2013).

37 "James Corner Field Operations and Diller Scofidio + Renfro." The High Line. http://www. thehighline.org/design/design-team-selection/field-operations-diller-scofidio-renfro (accessed November 4, 2013).

38 Moore, Rowan. Why we build. London: Picador, 2012: 294.

39 Ibid: 291.

40 Genette, Gérard. Paratexts: thresholds of interpretation. Cambridge: Cambridge University Press, 1997: xix.

41 Camille, Michael. The gargoyles of Notre-Dame: medievalism and the monsters of modernity. Chicago: University of Chicago Press, 2009. Print: 4. Ibid: 4 . 


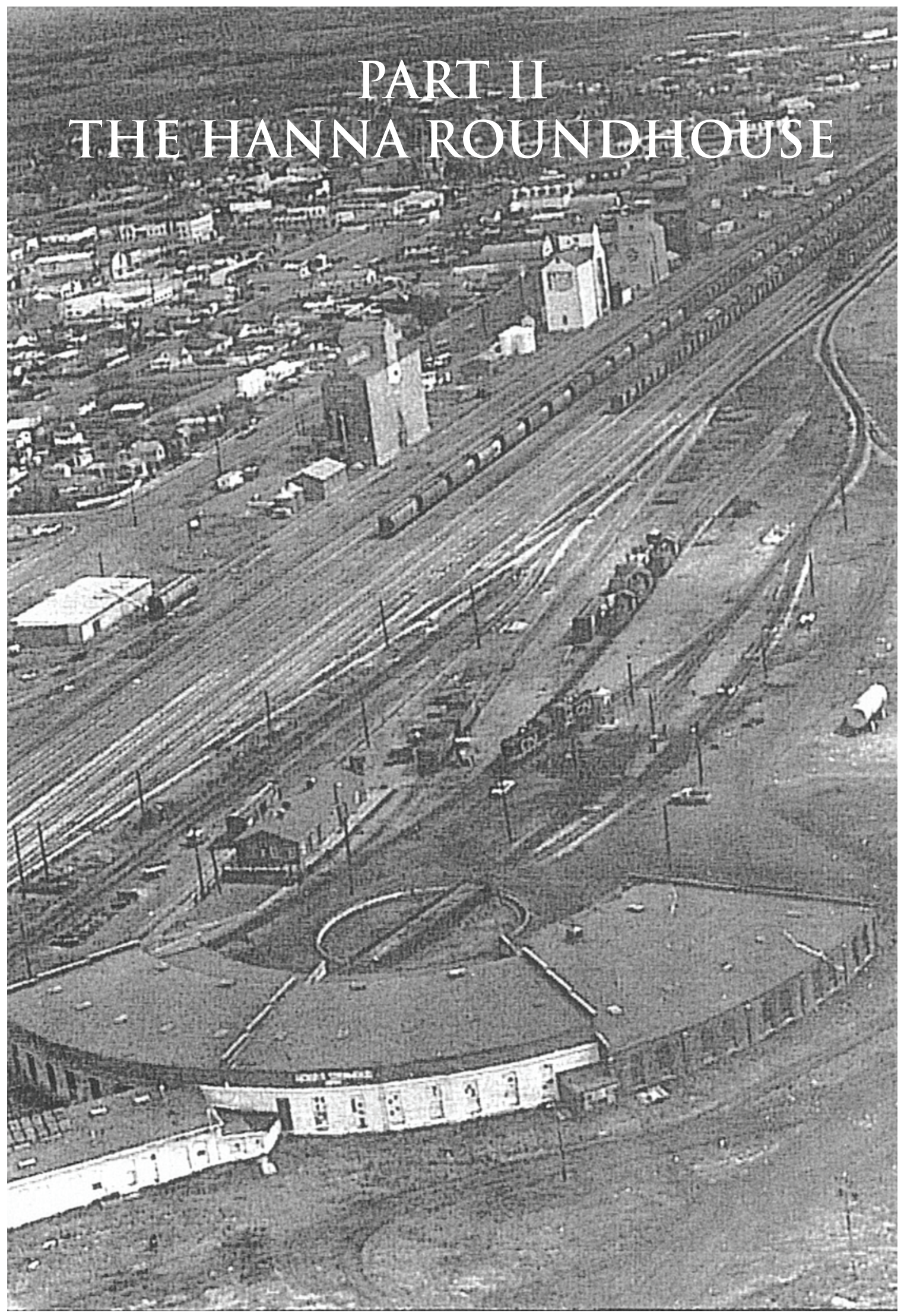

Figure 2.1 Aerial view of the Hanna, Alberta railway yards and shop - looking East, 1981. 


\section{PROJECT SITE: HANNA, ALBERTA}

The project site was selected based on its rich and varied history that would allow for a transtextual examination of the historical layers. Hanna is a small town located in EastCentral Alberta, Canada, about a 2-hour drive $(215 \mathrm{~km})$ North-East of Calgary. The main access to Hanna is via Highway 9, which runs just South of the town. According to the 2011 Canadian Census, Hanna's population is 2,673 people. ${ }^{1}$ Originally, Hanna began as a railway divisional point in the beginning of the $20^{\text {th }}$ century. By the 1950 's however, the railroad's influence on the town was beginning to diminish leading to the railway's closure in 1961. After the railway left, other service initiatives were implemented to reduce the depopulation. Since the beginning of the Alberta oil boom, Hanna has hosted a representative group of oilfield production and service personnel. ${ }^{2}$

Today, Hanna is the main service town in East Central Alberta for neighbouring rural farmers and ranchers seeking banking, professional, medical and shopping services. ${ }^{3}$ Its largest tourist attraction is the annual Indoor Pro Rodeo held at the end of September. Other tourist activities include golfing, camping, hunting, fishing, and a Pioneer Village, which consists of a collection of historic buildings and local archive. There are still remnants of the rail yards in Hanna including the Roundhouse. This building has a rich social and morphological history. It is through this design project that transtextuality can be applied to the elements of Hanna's railway past. 


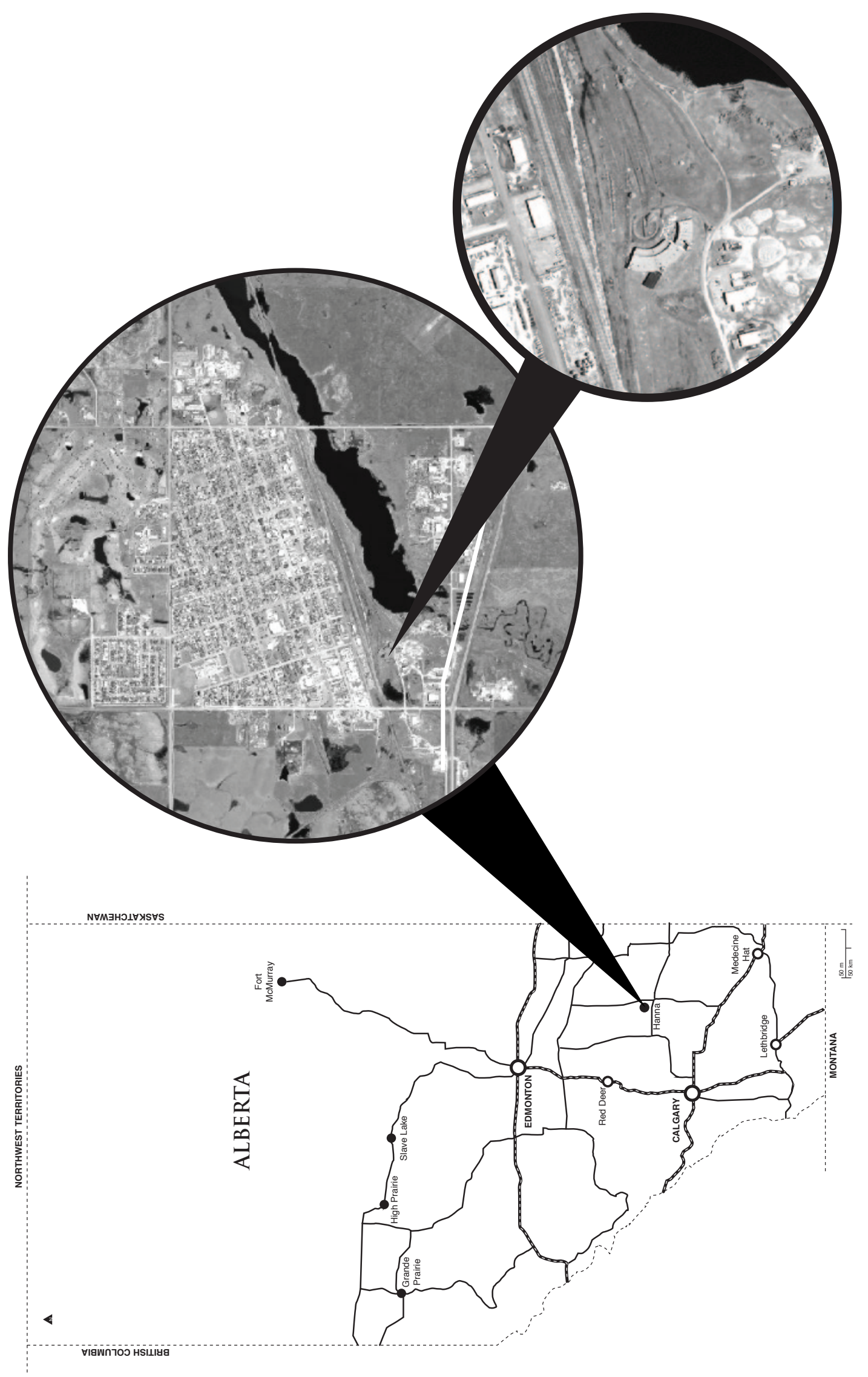

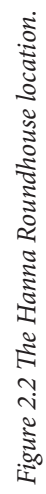




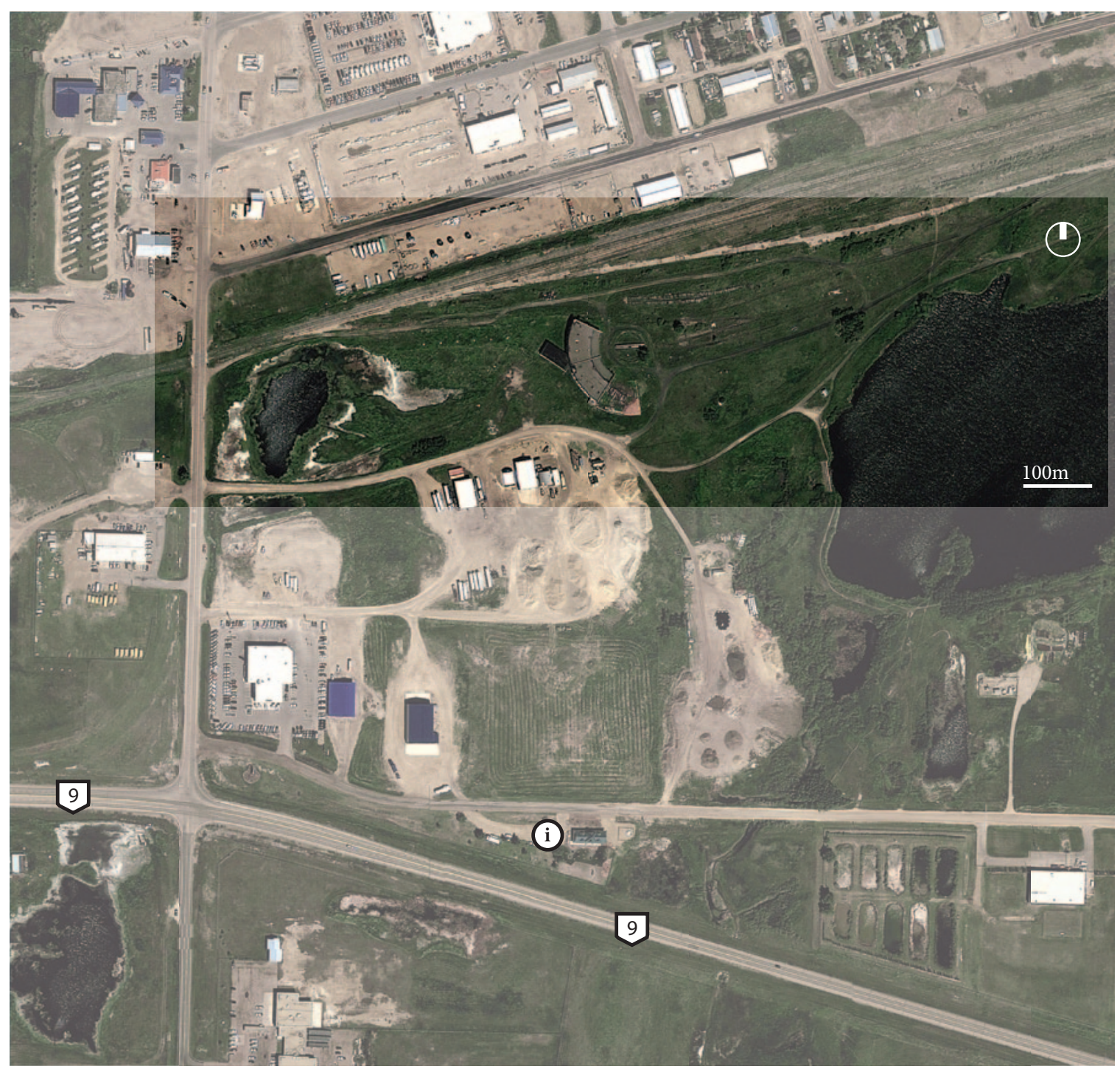

Figure 2.3 The Hanna Roundhouse contextual map. 


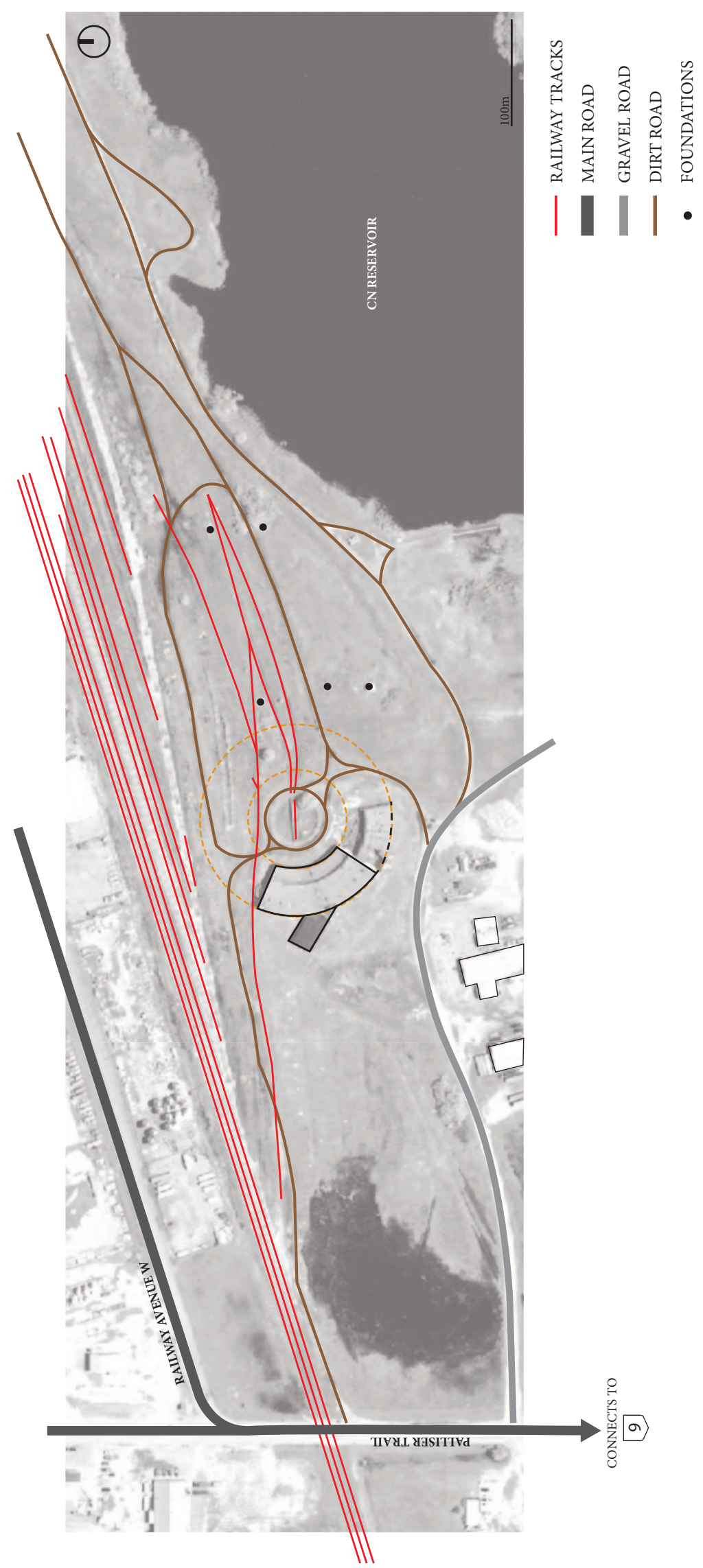

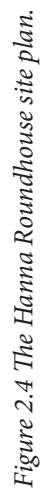




\section{HANNA'S RAILWAY HISTORY}

Hanna's origins are intrinsically linked with Canada's railway history. The Canadian Northern Railway (CNoR) was established in 1899 by William Mackenzie and Donald Mann in response to the monopoly of the Canadian Pacific Railway (CPR). At the time, the Canadian Government was promoting settlement in the West and the railway industry was the best way to achieve this. The CNoR provided a more affordable solution than the CPR, thus giving the CNoR the nickname the "settler's railroad."4 From 1901 to 1916 the CNoR expanded to include more than 9,000 miles of track. As the railroad expanded, new towns needed to be built along the track in order to service the trains (which were steam locomotives at the time). These service towns were known as divisional points. At the time, the designation of a town as a divisional point "virtually ensured a community's economic future." ${ }^{5}$ This of course is completely reliant upon the railroad and its success.

By 1911 the CNoR had completed surveying the land in order to connect Saskatoon with Calgary. This rail line would be called the Goose Lake Line and would bring settlers and supplies to areas not yet serviced by the railway. David Blythe Hanna was the executive of $\mathrm{CNoR}$ at the time, and it is his name that was given to one of the most important divisional points along the line: the town of Hanna. With the promise of a railroad, many people moved to Hanna in order to find work (with the CNoR) and to be close to a service line. By the end of $1912 \mathrm{CNoR}$ had laid tracks into the town and on June 8, 1913 construction began on a 10-stall roundhouse, a 70' diameter turntable, and a 60,000 -gallon water tower. When the roundhouse was completed and ready to service locomotives, it became clear that Hanna was going to be a major service point: "everything around the yards [in Hanna] point to this being one of the main divisional points of the CNoR in this province. The best of everything has been installed." 6 
By 1917 the Canadian Government took over the CNoR, in addition to other smaller rail lines. Two years later they would be amalgamated into the Canadian National Railway (CNR). Under the CNR in 1919, five additional stalls were added to the roundhouse in Hanna. These stalls were taller and longer than the original 10 and made out of brick instead of concrete (this would result in its collapse almost 100 years later). The roof of the original 10 stalls had to be raised in 1943 to improve ventilation and accommodate larger locomotives. This created a clerestory row of windows and brick bands atop the concrete walls.

Trouble for roundhouses everywhere began around the 1950's when diesel engines began to replace the steam locomotives. Finally in 1961 the Roundhouse and CNR rail yards closed. Since its closure the Roundhouse has been used as a machinery centre as well as a cattle auction. For the past several years, however, the roundhouse has been abandoned. This has attracted photographers and railway enthusiasts, as well as the interest of people looking to reuse the structure and site. As of September 2013 the Hanna Roundhouse Society, a local not-for profit organization, purchased the roundhouse in hopes of restoring and reusing it for tourism and community activities.

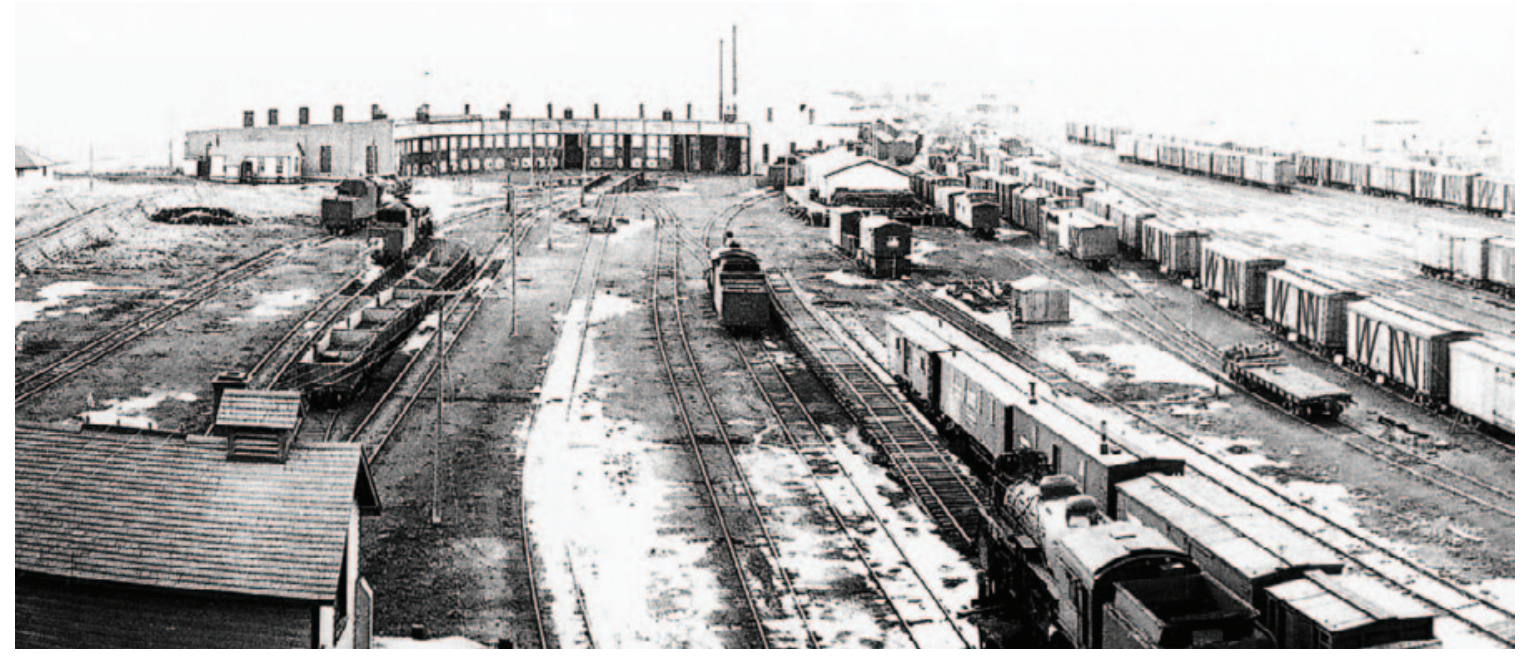

Figure 2.5 The CNR railayrd, Hanna Alberta. (1920's). 


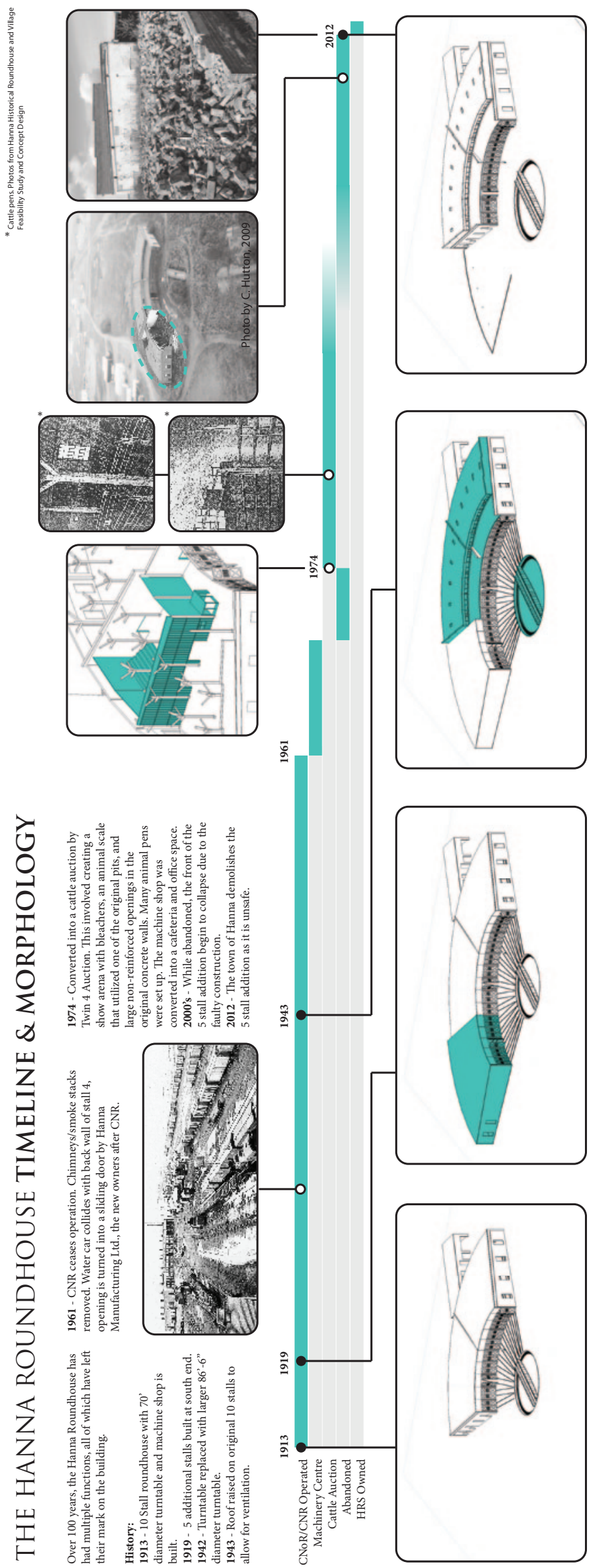

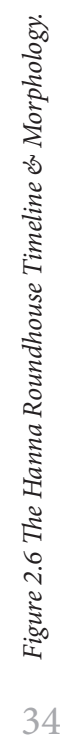




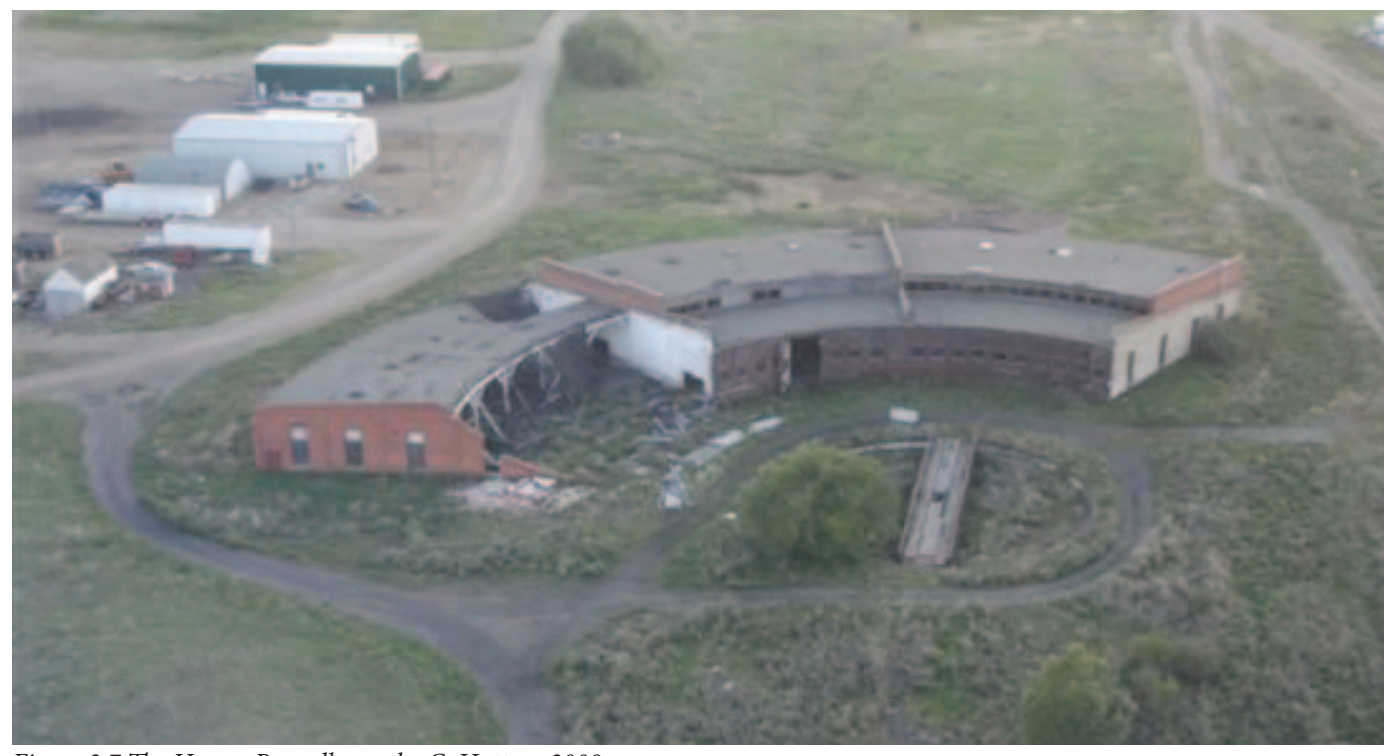

Figure 2.7 The Hanna Roundhouse by C. Hutton, 2009.

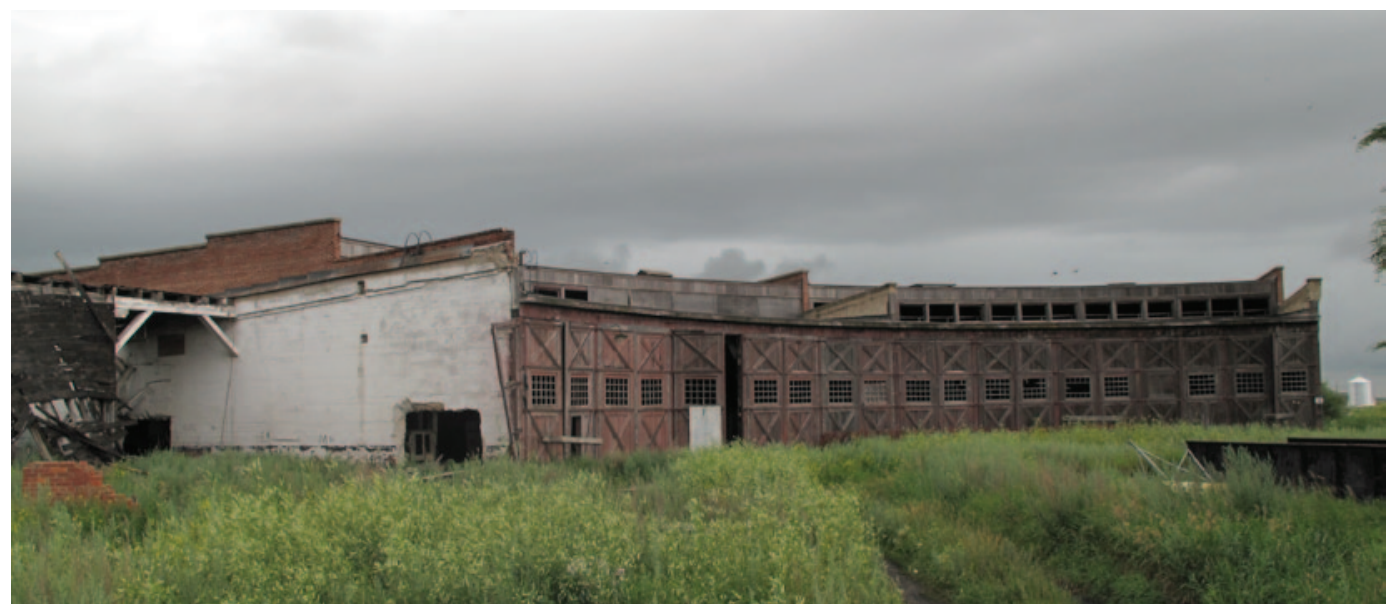

Figure 2.8 The Hanna Roundhouse by C. Moorhouse, 2011.

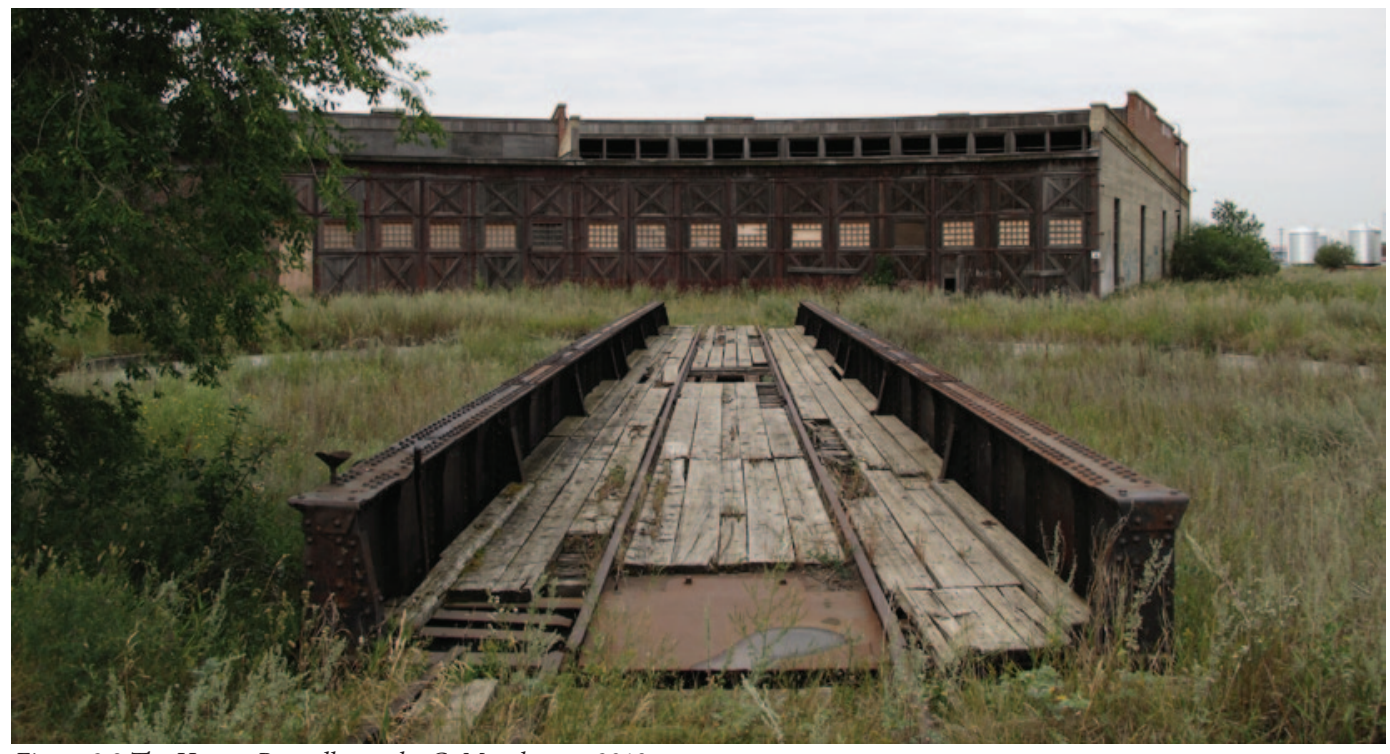

Figure 2.9 The Hanna Roundhouse by C. Moorhouse, 2013. 


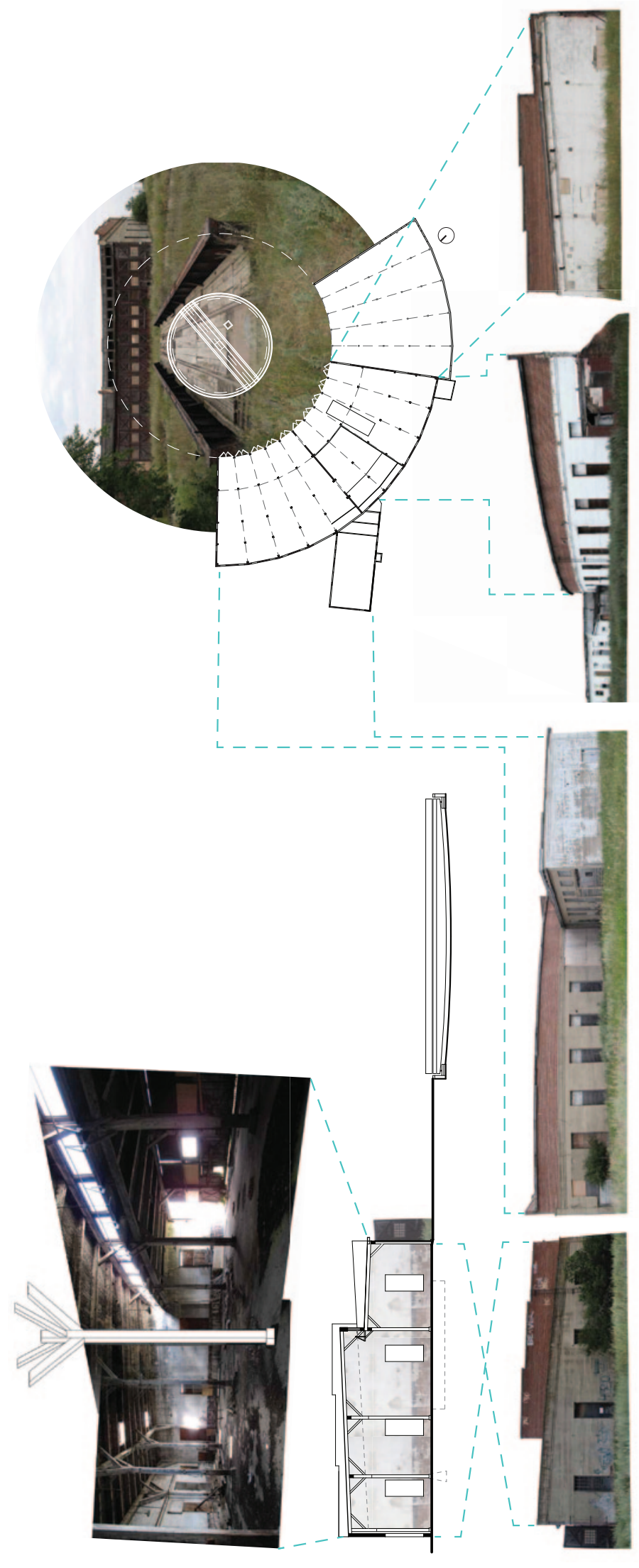

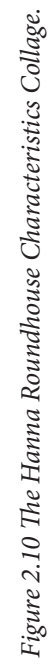




\section{ADAPTIVE REUSE PROGRAM}

During the summer of 2013 I met with Sandra Beaudoin, the President of the Hanna Roundhouse Society, and communicated via email with Laurie Armstrong, Director of Business \& Communications of Hanna. At the time the Hanna Roundhouse Society had plans to purchase the Roundhouse and reuse it (they subsequently purchased the roundhouse in September 2013). My communications with Beaudoin resulted in the idea of reusing the Roundhouse as a museum that was to be financially supported by ancillary programs. ${ }^{7}$ My conversations with Armstrong revealed Hanna's lack of adequate performance space and accommodations. ${ }^{8}$ As a result, the programmatic vision derived from these conversations includes the Roundhouse as both a museum in remembrance of Hanna's railway history, as well as a community gathering space and local landmark. To support the Roundhouse financially, and the community as a whole, a café and performance space will be included. The café will provide food services to community events held on site, as well service highway travelers. Beaudoin would also like to take advantage of the Roundhouse as a cultural icon and have it host shops that would sell locally crafted goods. ${ }^{9}$

\section{THE ROUNDHOUSE'S EXISTING CONDITION}

At the outset of the project I searched the Provincial Archives of Alberta as well as the National Library and Archives in Ottawa for an original plan of the Roundhouse but was unsuccessful. Beaudoin provided me with a copy of the Hanna Historical Roundhouse and Village: Feasibility Study and Concept Design, which was published in 1981 and contains site drawings by Hilderman Feir Witty \& Associates. In the feasibility study Hilderman Feir Witty \& Associates reference original plans on file at the CNR Architectural Division in Edmonton. I tried several times to contact CNR but was unsuccessful in tracking 
down the plans. Fortunately I spent much of the summer of 2013 on site taking my own measurements and photos of the Roundhouse, from which I derived my own technical plans.

In 2010, at the request of Beaudoin, Williams Engineering conducted a structural evaluation of the Roundhouse. The evaluation revealed the original walls to be concrete (Williams Engineering believe it to be unreinforced), with heavy timber columns and wood construction. The timber framing appears to be in good condition. ${ }^{10}$ The concrete walls and central shear wall (between stalls 5 and 6) also appear in good condition except for the openings that were created under the ownership of Twin 4 Auction in the 1970's. These openings have created cracks and should be reinforced. ${ }^{11}$ The wood roof, however, is in need of repair or to be replaced entirely. Bricks atop the original concrete walls have supported the wood roof since the roof was raised in 1943. These bricks appear to be in good condition with minor visible cracks. The cattle auction arena, also added by Twin 4 Auction, consists of wood framing in poor condition and should be demolished. ${ }^{12}$ Most of the windows throughout the structure are either in a state of partial or complete decay. According to the evaluation in 2010, Williams Engineering estimated a structural rehabilitation cost of $\$ 157,000$. At the time of the evaluation the 1919 five-stall addition was in a state of partial collapse. Since it's demolition in 2012 it is no longer a safety concern. Many of the bricks and heavy timber from those stalls have been piled up on site for future reuse. 

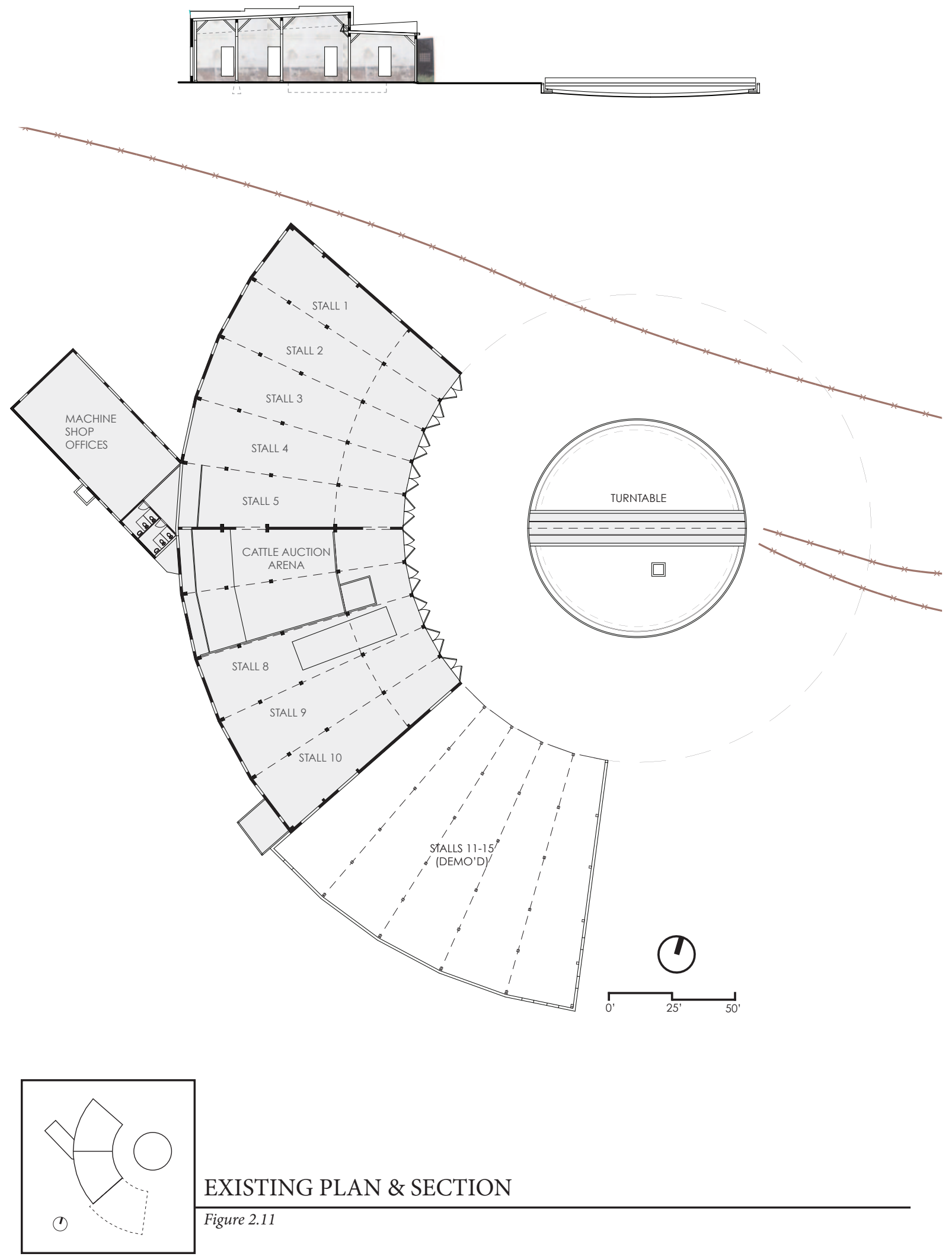


\section{A TRANSTEXTUAL APPROACH TO DESIGN}

Before I transtextually approach the adaptive reuse of the Hanna Roundhouse, I would like to clarify how the transtextual terms align with various design intents, primarily paratextuality, metatextuality and hypertextuality. In my opinion, these three terms appear to achieve certain design goals whereas intertext and architext perform more as a means to an end and exist primarily at the scale of a detail.

Paratextuality as a threshold of understanding relies on particular design intent and then is used to execute said intent. With heritage architecture, it is often related to conservation and preservation, as the intent is to experience the building as it is/was. Hypertextuality, unlike paratextuality, is against preservation which aims at maintaining a structure as-is. It is a primarily transformative relationship. In regards to metatextuality there are the two types: those that are influenced by precedent studies and those that reference another text without containing an intertextual relationship.

Designing for the adaptive reuse of the Hanna Roundhouse, I will be selecting certain architectural moments at different scales (including character defining elements, materiality, form, movement through the site, programming etc.) and exploring their potential as paratextual, metatextual and hypertextual. I will also include intertextual and architextual relationships when appropriate. By repeating the same detail or design according to the terms I will illustrate the differences and architectural position of each. 
In order to determine what details need to be explored, the design needs to progress with a clear design intent: this is where the subjective narrative of the author comes into play. It is important to me that the Roundhouse remains an artifact and therefore decisions will be based on this idea. By 'artifact' I mean that the building's historical record be visible and expressed while hosting new contemporary programs. While the integration of the new programs have the potential to be destructive towards the character of the roundhouse, my design will attempt to limit this. New construction will read as new and represent the second life that the Roundhouse has taken on within the existing historical narrative. Figure 2.11 illustrates this design process of reusing the Roundhouse as an artifact while exploring possibilities through transtextuality.

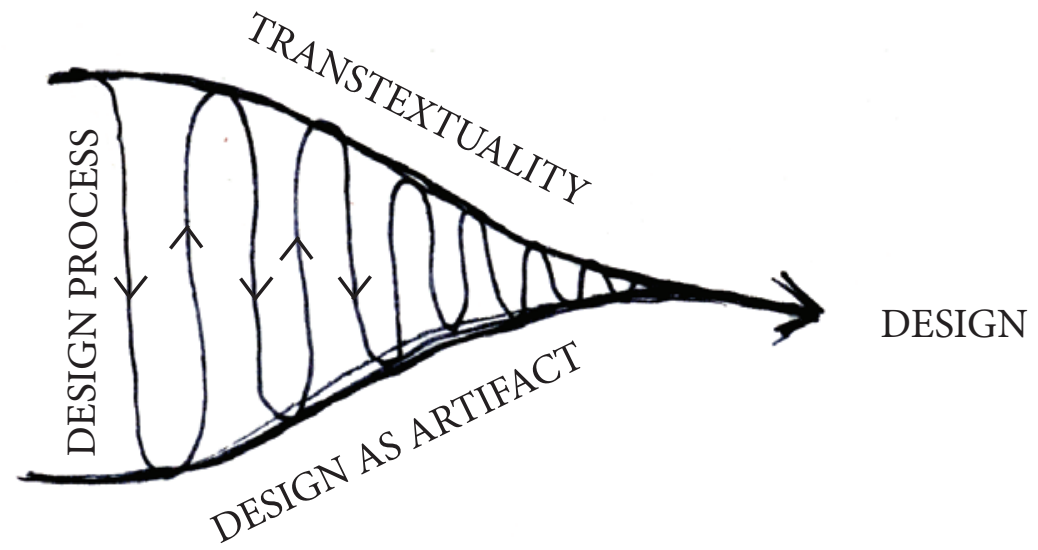

Figure 2.12 Design methodology.

\section{FORM AND PROGRAMMING}

The existing form of the roundhouse is a strong and defining characteristic. As such, how the form is treated in the adaptive reuse process is a critically important design decision. Referencing the curvature of the existing form offers a starting point to begin transtextually exploring the adaptive reuse possibilities for the Roundhouse. 


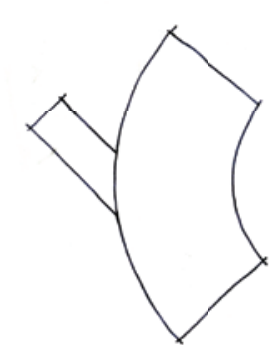

Figure P1
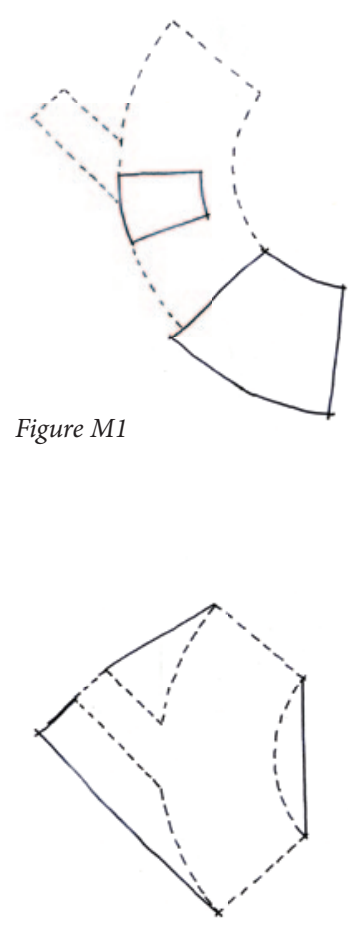

Figure H1

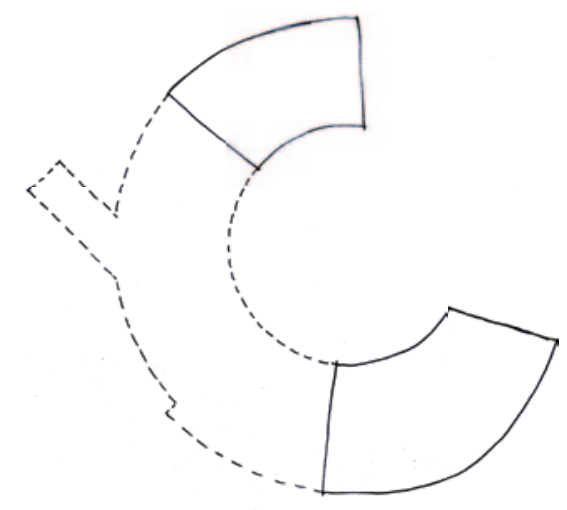

Figure A1
Figure P1 aims at maintaining the form as it is and is therefore paratextual in nature. To achieve this the new program will need to fit within or completely outside of the existing form.

Figure M1 is a metatextual approach to the form as it recreates the form of lost texts (i.e, the cattle auction arena in the centre that, according to engineer's report is unstable; the demolished stalls of 11-15). This is not calling for complete reconstruction of the lost texts; it is simply suggesting that new additions reference these texts spatially.

Figure $\mathbf{H 1}$ is a hypertextual example. Any new construction that alters the physical form of the building can be considered hypertextual. This can take a multitude of forms and can involve the removal of existing walls, floors, and roofs.

Figure A1 is an architextual example and relates to the roundhouse typology. Typically the curved design of the Roundhouse allows for growth around the centre as rail yards expand. This design suggests an addition that follows the radial form, and as such acts as an indicator of typology. While this suggestion references the general context of roundhouse forms/structures, it is a foreign extension to this particular site since it never previously existed. 
The program will be divided into three zones: new construction for all year use, sheltered and heated spaces for summer and occasional winter use, and finally uninsulated and unheated spaces for seasonal use. Transitioning between these zones creates a gradient of thermal experience and fits within the existing three zones identified by stalls 1-5, 6-10 and the demolished stalls 11-15. Programmatically the theatre and performance space will be contained within the new construction so that it can be used all year as a source of revenue. The café and shops will be sheltered and heated for occasional operation. This allows them to exist within the Roundhouse without demanding major alterations to the existing envelope and structure. Finally the museum will be sheltered (since artifacts will remain within the structure) however the designated area will not be altered for insulation and air tightness in order to preserve its authenticity.

Prior to progressing to the design of the three spaces I have transtextually explored the effects of insulation on the Roundhouse. 

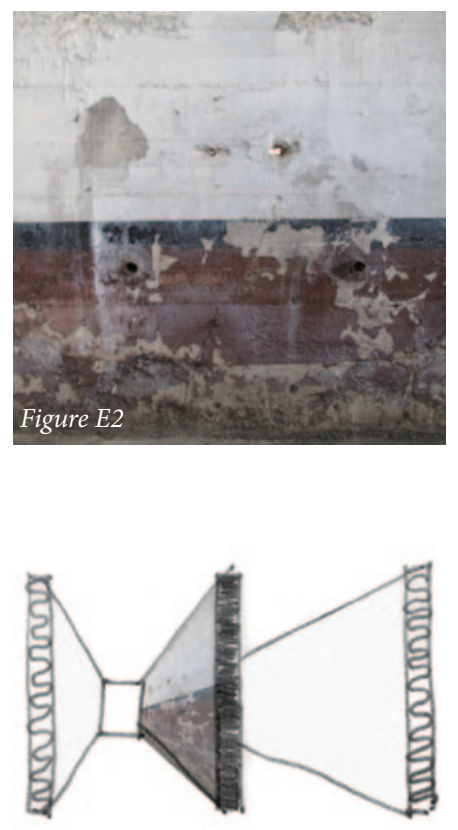

Figure P2a

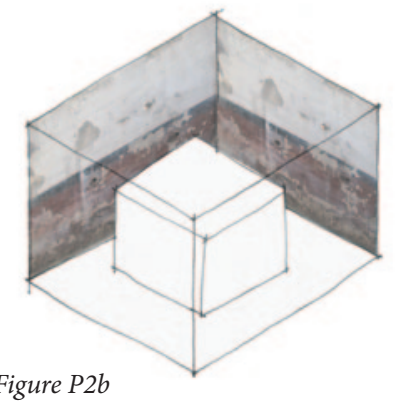

Figure P2b

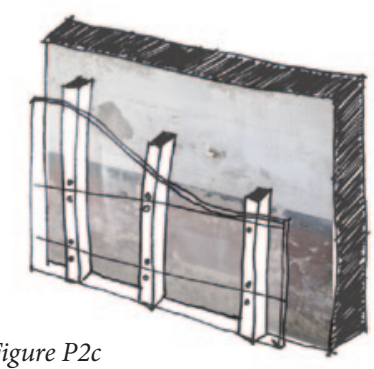

Figure P2c

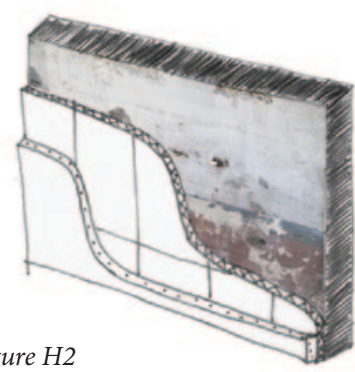

Figure E2 is a photo of the existing concrete wall along the North side. The photo is taken from the interior. The existing wall is not insulated and contains numerous holes and cracks.

Figure P2a is a paratextual addition of new programs that leave the existing walls intact by encapsulating/ enclosing the existing walls within a new insulated wall. This preserves the visual and tactile nature of the wall.

Figure $\mathbf{P} \mathbf{2 b}$ is another paratextual example of where the new program exists self-contained within the Roundhouse, so as to avoid insulating these existing walls. The new program could be properly insulated and sealed via its new and noninvasive form.

Figure P2c is another paratextual example, where a glass wall system is installed next to the existing wall. The thermal value is then determined by the R-value of the selected glass. This example preserves a visual connection to the existing wall.

Figure $\mathbf{H} \mathbf{2}$ is a hypertextual example because it transforms the character of the wall by covering it up with new insulation and interior (or exterior) finish. While perfectly common in modern adaptive reuse, for the sake of my project this example represents that which I am trying to avoid. 


\section{THE MUSEUM}

As mentioned before, the museum program will be contained within a portion of the ruins and will therefore be seasonal. Stalls 1-5 to the north have seen the fewest alterations over time, and are therefore the truest remaining representation of the Roundhouse's original function and thus the best location for the museum program. While I am designating these stalls as the location for the museum artifacts, the desire that the Roundhouse as a whole remain as an artifact will influence design decisions in other areas of the site/building. The museum will contain a series of information panels, a few artifacts, and a steam locomotive. At this point in time these artifacts have not been obtained, however there are a few items in the Pioneer Village that could be relocated to the Roundhouse. With an open plan the space can be used in the summer to host a farmers market, celebrations such as weddings, as well as other spontaneous uses.

While it may seem odd at first that the primary function of the Roundhouse redesign is seasonal, this is a typical practice in Alberta's rural communities. The Roundhouse in Big Valley, Alberta, for example, has an entirely outdoor information display. ${ }^{13}$ Also, due to harsh winters, unsafe road conditions, and resulting reduction in tourism, many of the attractions in Hanna and other small communities close down for the winter. By containing the artifacts within the shelter of the Roundhouse they can still be accessible for special occasions during the colder months. Much like Sverre Fehn's Archbishopric Museum of Hamar, however, visitors will be greeted with the cold crisp air. ${ }^{14}$ The cold will heighten the visitor's sense of the ruin and passage of time. While insulation is not a primary concern for this portion, preventing access by animals and people through the open windows is. I have transtextually looked at how the windows could be treated. For the museum portion it is important to maintain the visual of the ruin and of its age, which is illustrated through the paratextual example that my design will adopt. 
Figure E3 is a photograph of an existing window condition along the North façade. There is no remaining glass, and the wood mullions and frame has been considerably damaged.

Figure P3 is a paratextual design. ${ }^{15}$ This example applies a pane of glass on the exterior and interior, encapsulating the deteriorated wooden frame and yet leaving it on display to be viewed as an authentic element that has decayed. There is no air seal, so there would be ventilation through the window.

Figure M3 is a metatextual design. This example references the art precedent "The River That Flows Both Ways" by Spencer Finch as part of the High Line. ${ }^{16}$ Finch's art piece is a series of glass panes tinted to a colour that corresponds to a photograph of the Hudson River. This design references that concept, but reinterprets it in grey scale. This grey scale on the windows also references the nature of the Roundhouse during its original operation since smoke often filled the building and created a dark environment.

Figure H3 is a hypertextual design. This example assumes that the wall has become an interior wall and therefore transforms the function of the window into a display for local art. The window has been cut to the floor with a new plinth and top form, which contain spotlights.

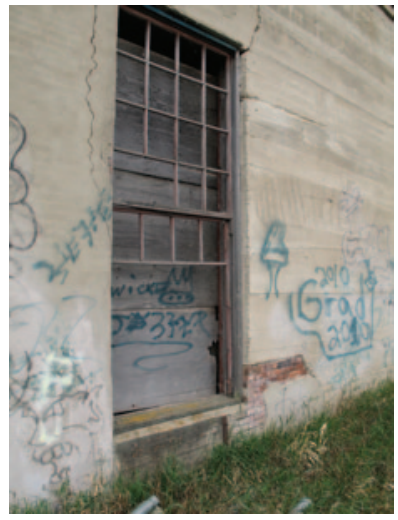

Figure E3

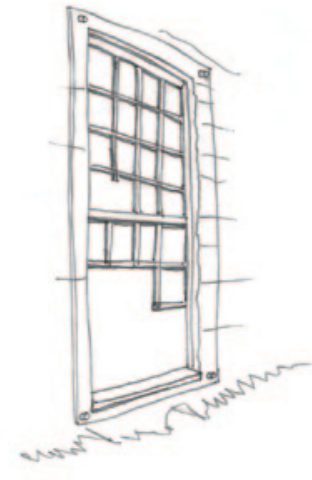

Figure P3

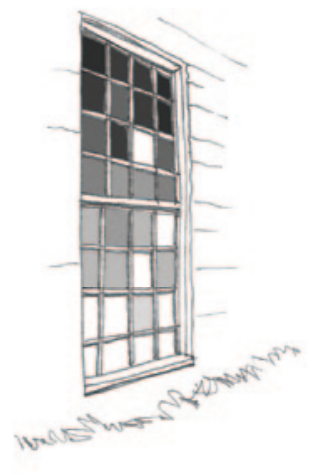

Figure M3

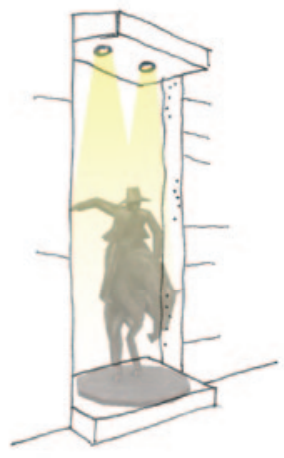

Figure H3 
In addition to the window design, I want to draw attention to the loss of the pits. During the Roundhouse's alternative uses after being closed by the CNR, the rails were removed and the floor was paved with concrete. In each stall there were originally pits that were approximately 4' deep, 4' wide and ran most of the length of the stall (these measurements were taken from the roundhouse in Big Valley, Alberta since that roundhouse is of similar construction and was built one year before the roundhouse in Hanna, see figure 6.2). These pits were used to drain and clean the engines of the locomotives. Now buried beneath the concrete flooring, I want to metatextually reference the pits' size and location in the building's plan. How I choose to go about this has paratextual undertones since what and how I decide to convey will influence the visitor's reading of the pits. Instead of opting for a rigorous ripping up of the concrete floors, which may not even reveal the pits in any salvageable state, I am opting for a more subtle approach. Since the concrete floor is smooth, I am opting to slightly rough up/chisel the surface area of the pits. This will create a contrast between the smooth and rough. I originally considered a form or painting to mark the location, but that would require maintenance and does not have the same longevity as actually carving into the existing concrete. While the smooth concrete seemingly removed the pits from the record, this etching will in some capacity return their visibility through subtle referencing. 

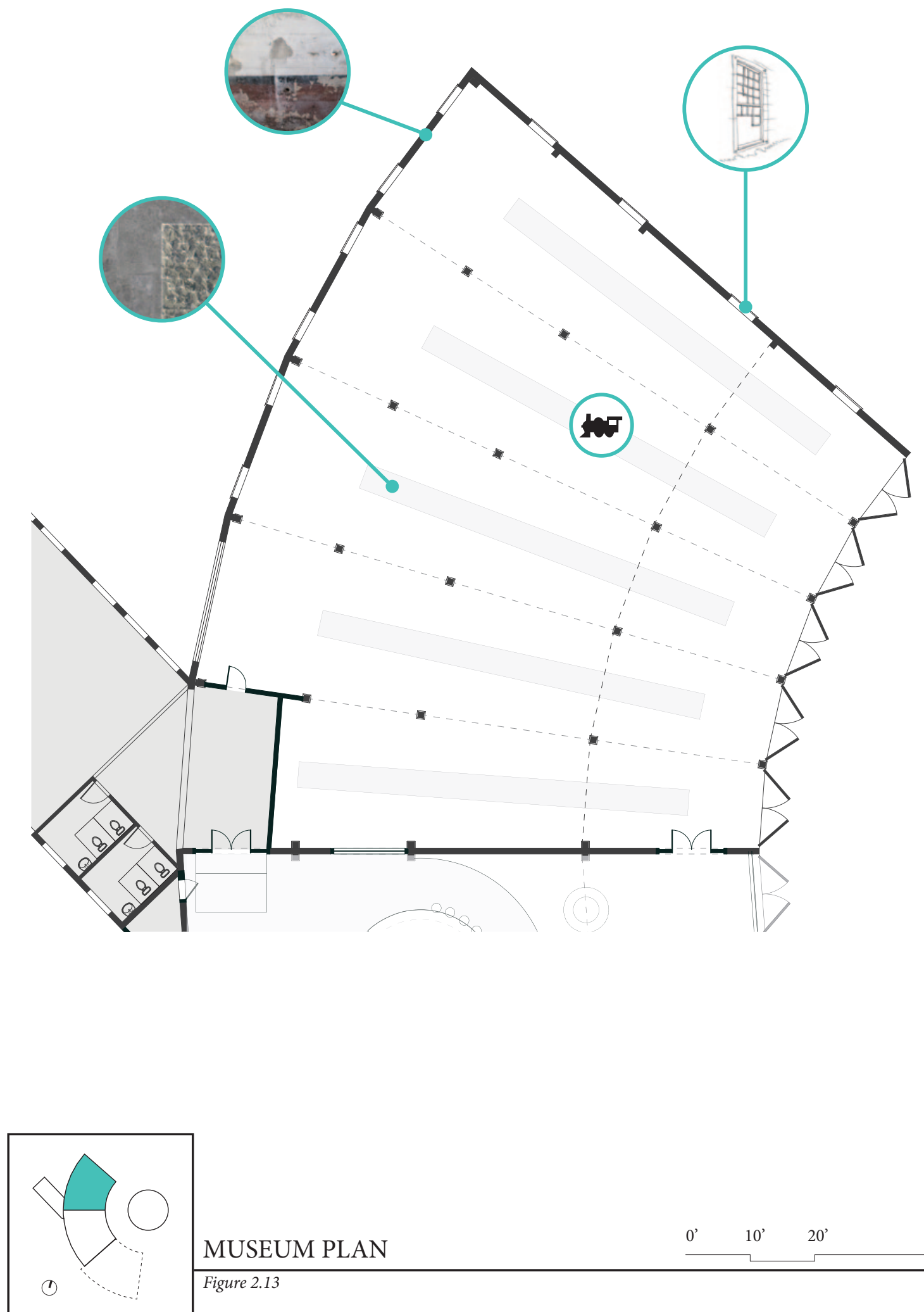

MUSEUM PLAN

$0^{\prime} \quad 10^{\prime} \quad 20^{\prime}$

40 

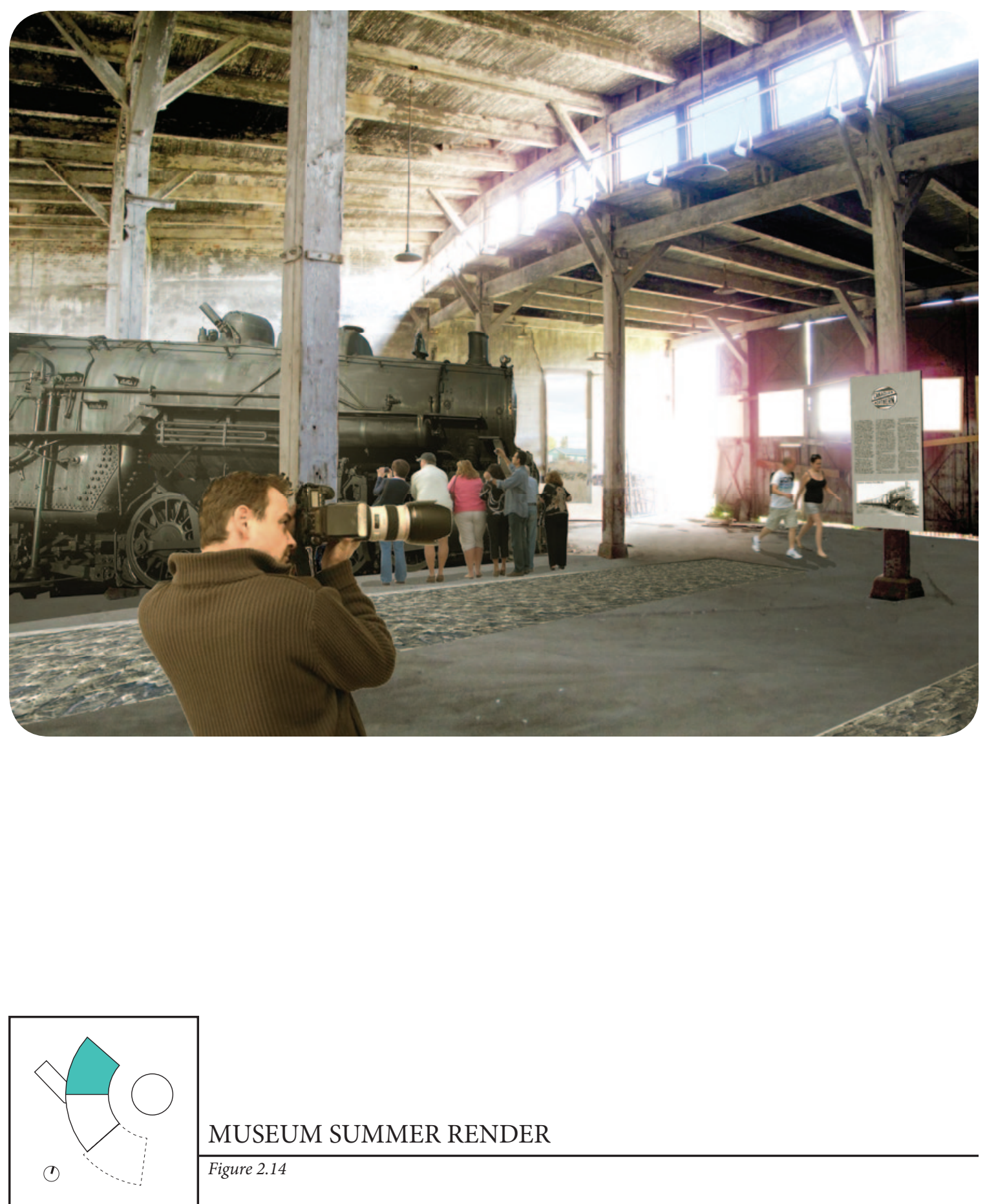

MUSEUM SUMMER RENDER

Figure 2.14 

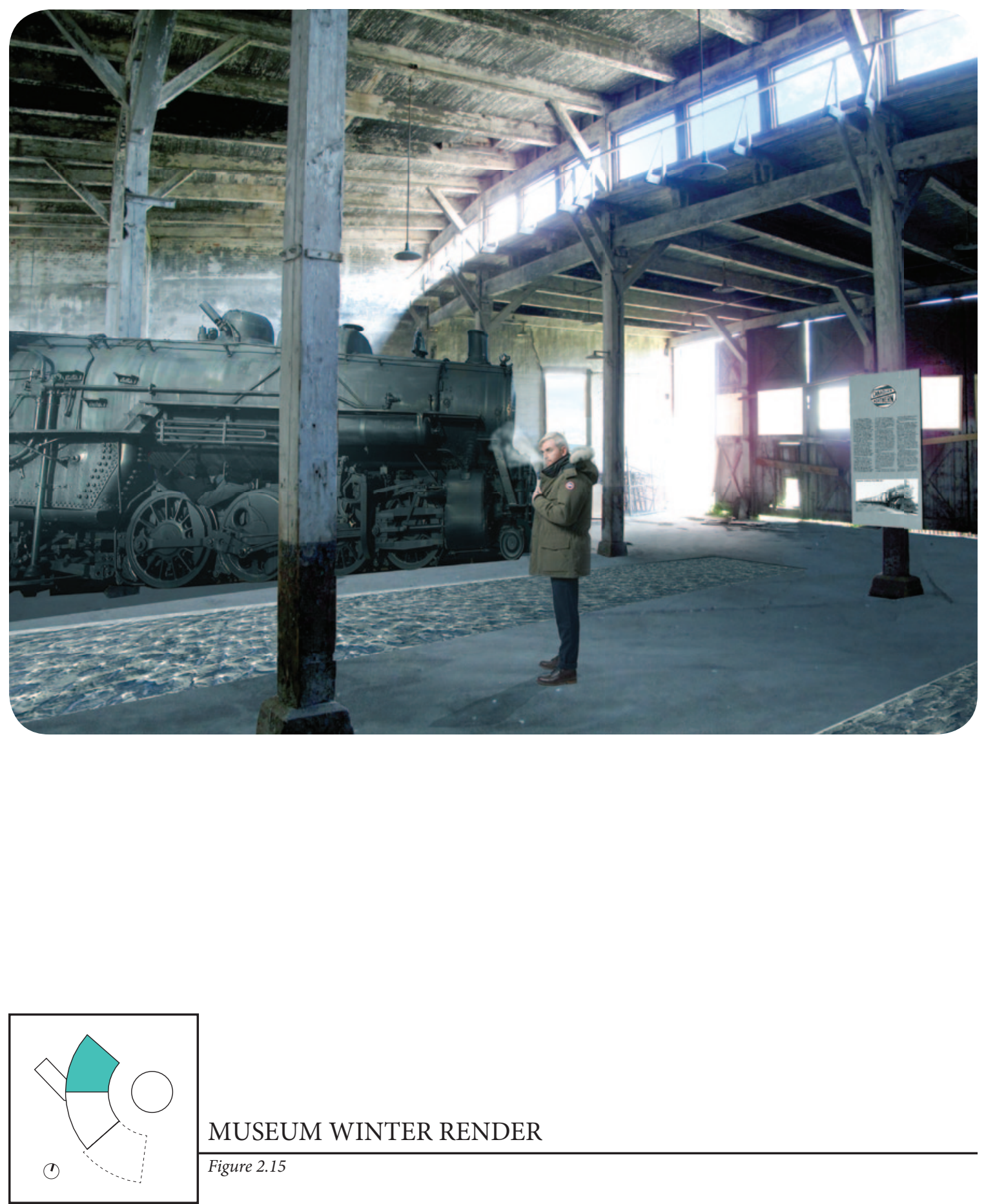

MUSEUM WINTER RENDER

Figure 2.15 


\section{THE CAFÉ \& SHOPS (STALLS 6-10)}

With the museum primarily contained within stalls $1-5$ and the theatre to the South in the demolished stalls 11-15 (to be discussed later), stalls 6-10 become a crucial connection between the two. The supportive programmatic nature of the café and shops benefits both the museum and theatre visitors. The café and shops will function seasonally like the museum, however, it is important that these spaces also be able to (on occasion) support the year-round operation of the theatre. As a result, heating, sealing and insulation are major concerns for this portion of the design.

In order to address these issues I originally pursued design options that related to creating a new insulated and sealed structure within the roundhouse (see figures 3.1-3.2). The nature of the space made these simple concepts very complicated. For example, structural geometries (curved and radial geometries as opposed to parallel) had to be considered, as did how to link the insulated theatre (one end of the space) to the insulated offices/ bathrooms/kitchen (other end of the space). These insulated offices/bathrooms/kitchen had been converted from the original machine shop during the occupation by the cattle auction. These programs will remain with some renovation. The kitchen in the machine shop will be used as the prep area for the café service bar, which will be located within the stalls 6-10.

Another significant feature to be tackled is the pit in stall 8. This pit is not an authentic representation of the original pits, which I have discussed previously. Instead, this pit has been significantly altered by the cattle auction and transformed into a cattle scale. Part of the original pit was covered in concrete and the remaining open portion was blasted to make it wider. The depth of the pit, however, has remained the same and is original. 
With all of these issues in mind, I opted to maintain the openness of the space instead of creating a new fully sealed and insulated structure within the Roundhouse. In order to achieve this the windows, openings, and doors would need to be sealed. The doors are character-defining elements that do not have a proper seal. Thus, creating a seal while maintaining the character of the doors has been transtextually explored:

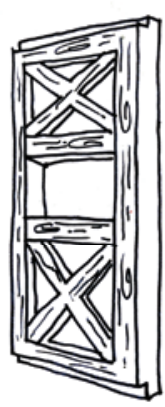

Figure M4

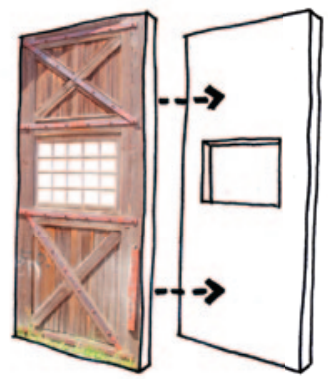

Figure P4a
Figure M4 is a metatextual example that assumes that the doors would be removed and preserved in another location (possibly in the museum). With the removal of the doors, these objects would become a previously existing text that could be metatextually referenced. Furthermore, the replacement doors would be casts of the original doors in order to maintain the wood grain and details of the construction as well as the memory of the doors.

Figure P4a is a paratextual example where the existing doors are mounted on to a new backing. The backing would provide an adequate $\mathrm{R}$-value and seal when closed. From the outside the original doors would still be read in place, although the backing would be visible from the interior. 


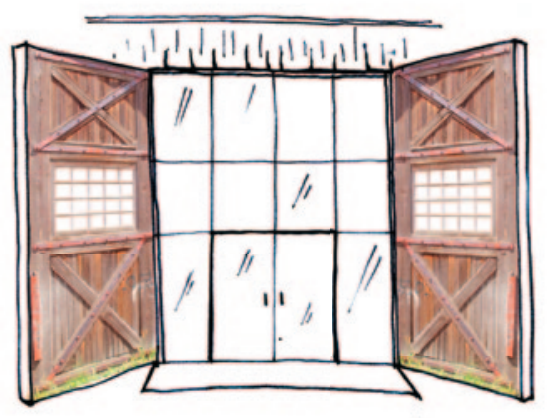

Figure P4b

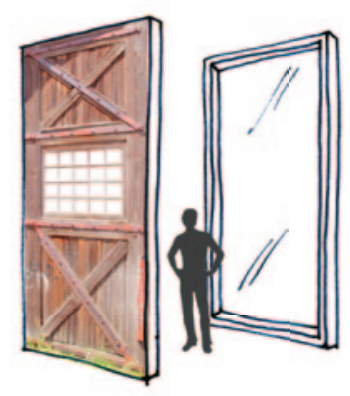

Figure P4c

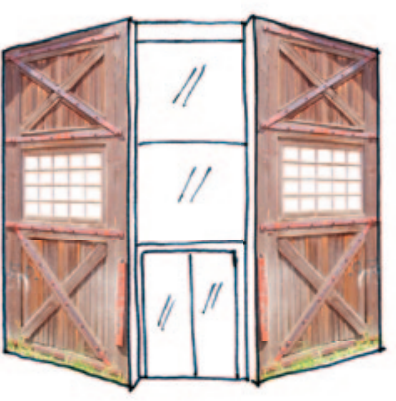

Figure P4d
Figure $\mathbf{P} \mathbf{4 b}$ is another paratextual example where a glass curtain wall is installed behind the doors. This would allow the doors to open and close normally without invasive treatments. The glass curtain wall would have an entrance in one of the stalls and the rest would just be glass. This would allow all the existing doors to be opened for daylight, while maintaining a singular entrance with a seal.

Figure P4c is another paratextual example that takes the same principles of figure $\mathbf{P} \mathbf{4} \mathbf{b}$ but pushes the glass curtain wall inwards from the existing doors. The glass curtain wall would be aligned with the first row of columns (also in alignment with the clerestory windows in section). The existing doors would still operate the same, but now when a visitor passes through this threshold they would be in a loggia that is still exposed to the outdoor conditions. This location intersects with the pit in stall 8 and would need to be detailed accordingly to provide a proper seal.

Figure P4d is another paratextual example. Instead of pulling the glass curtain wall inwards, as in figure P4c, the main entrance would be pushed outwards and the existing doors would be mounted and used as the sidewalls. 
Since insulating the Roundhouse would be a hypertextual transformation of its authentic material expression (figure H2) I am refraining from insulation. This means the space will become very cold in the winter. In order to combat the cold for occasional winter use (i.e. if it is to be used during a theatre performance) heat will be introduced in a pathway along the ground. The high ceilings and thermal stack effect of the Roundhouse make such baselevel heating the best option. This radiantly heated path will guide visitors and influence their interaction in the space through temperature. The radiant floor system will be controlled from an insulated room next to the washrooms in the machine shop structure. The pathway will sit on top of the existing floor of the roundhouse to minimize its impact on the existing structure. The café service bar will have mounted infrared heaters and act as the epicenter of heat and gathering in the space. Benches will be placed under the West windows and will be electrically heated in order to act as warm seating and also counteract the cold windows. In the summer, when these heating elements aren't required, they will remain as animators of the space allowing visitors to interact and move about the space freely.

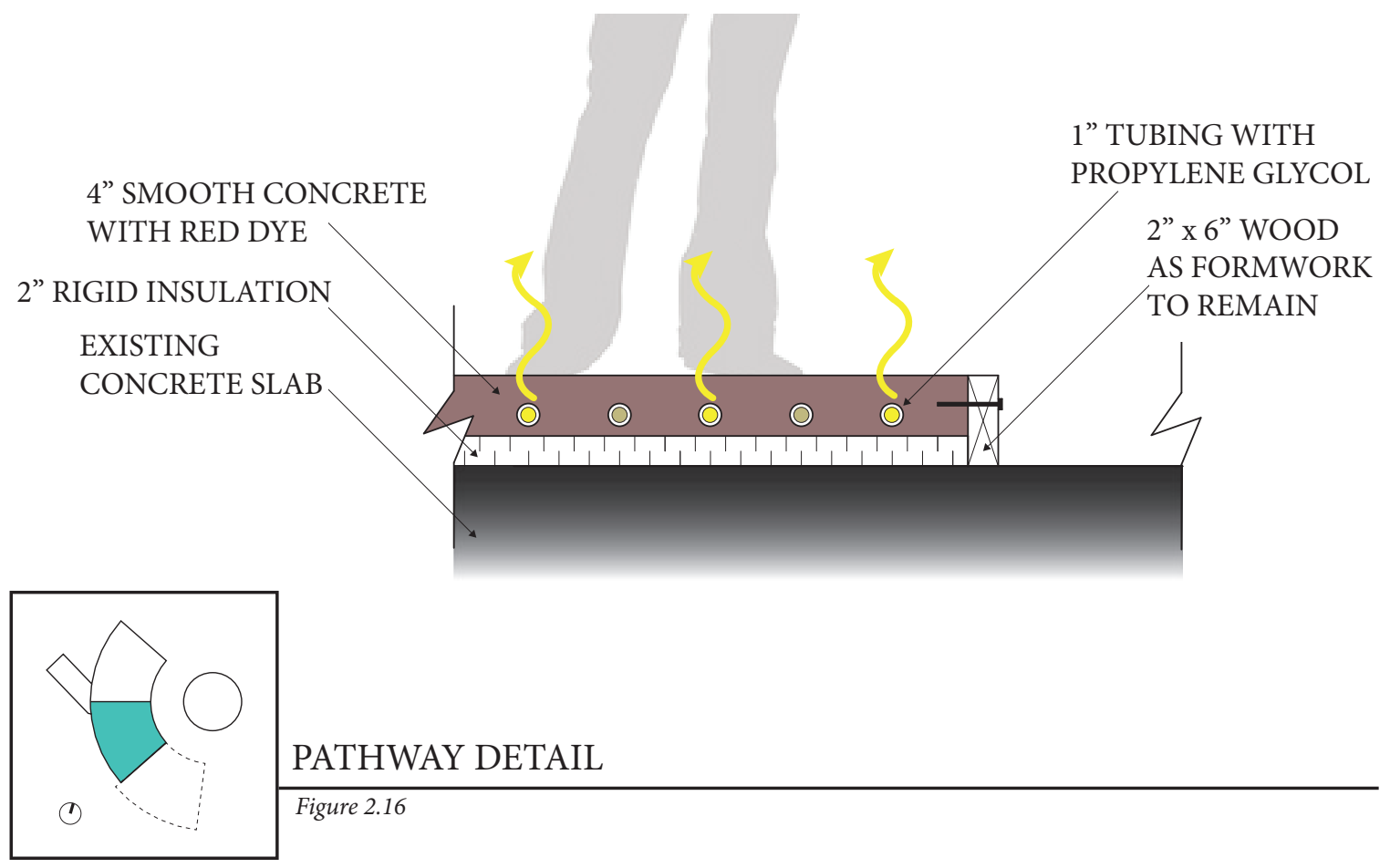



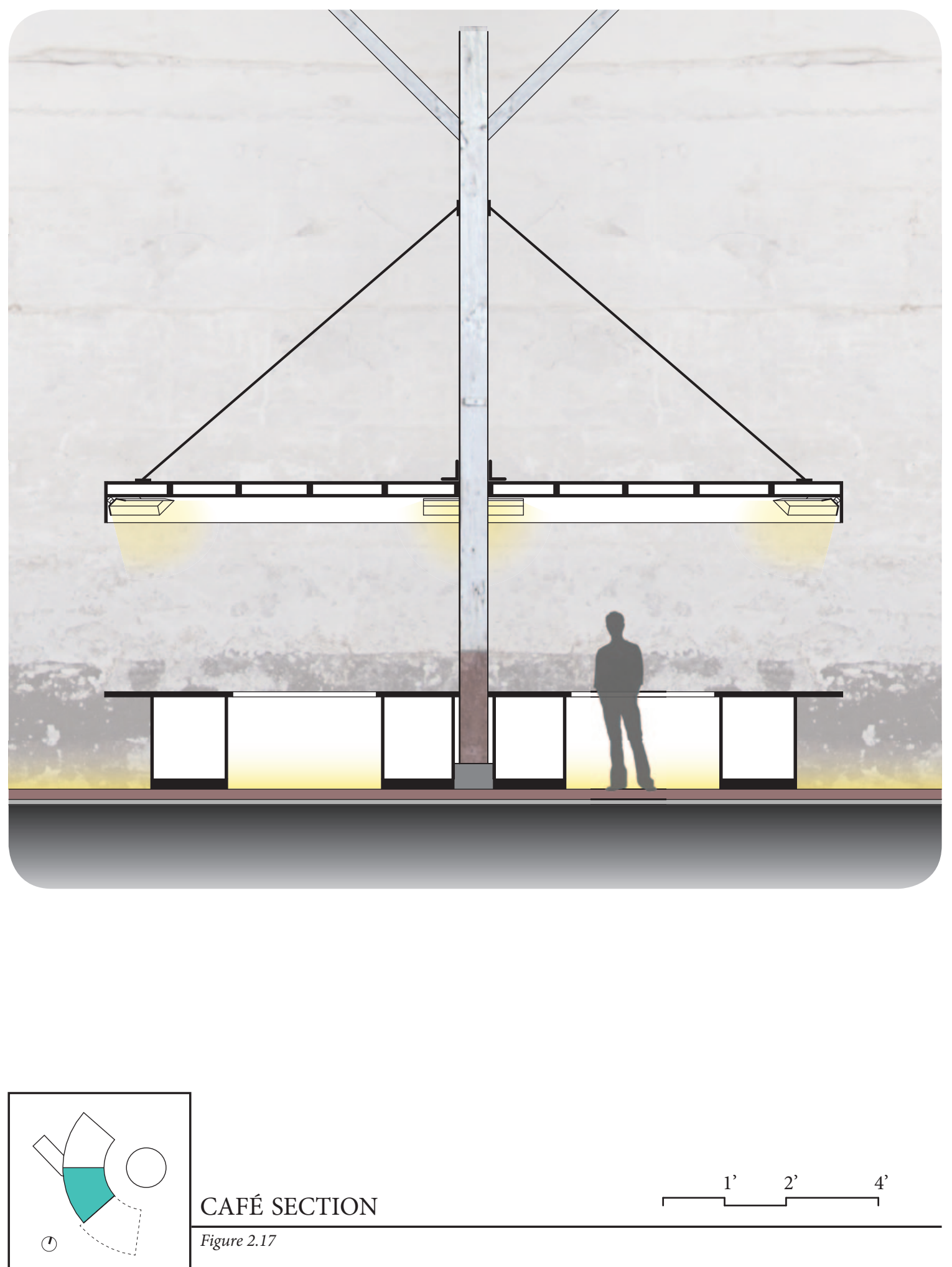

CAFÉ SECTION

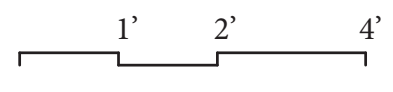

Figure 2.17 
The pit in stall 8 is one of the inherent interests in the space that visitors will be able to explore. Treatment of the pit has been transtextually explored as follows:

Figure $\mathrm{E} 5$ is a representation of the existing pit condition in stall 8.

Figure P5 is a paratextual example where the pit is covered in glass to allow visitors to walk over it and still maintain a visual of the sunken condition.

Figure M5 is a metatextual example that is similar to figure P5, however, it goes a step further by reintroducing the geometry of the original pit. The glass also steps down to reinforce the sunken nature of the space.

Figure $\mathbf{H} 5$ is a hypertextual example where the space is reimagined as an interior planting bed. The portion closest to the doors would be a rock garden since this area does not have a lot of natural light. The portion further from the doors could support plant life as it is in a well-lit area.

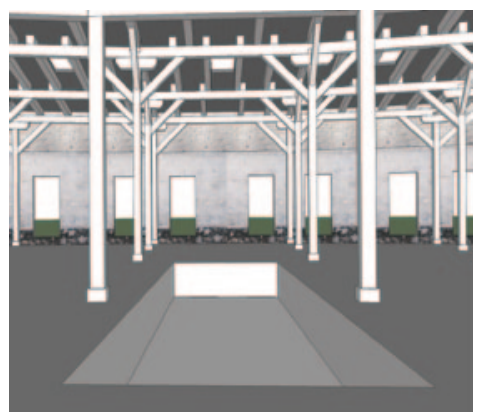

Figure E5

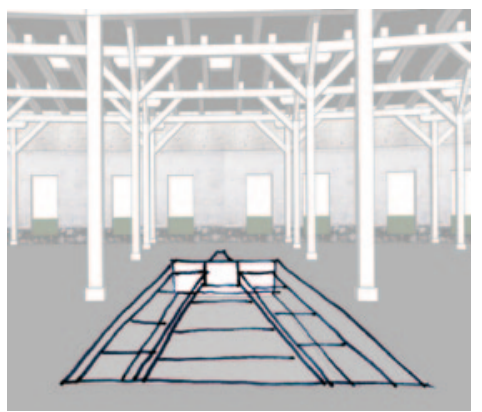

Figure M5

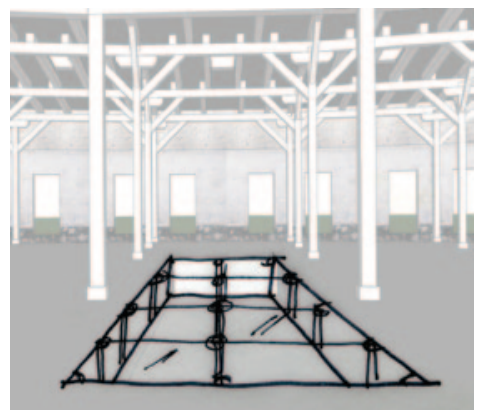

Figure P5

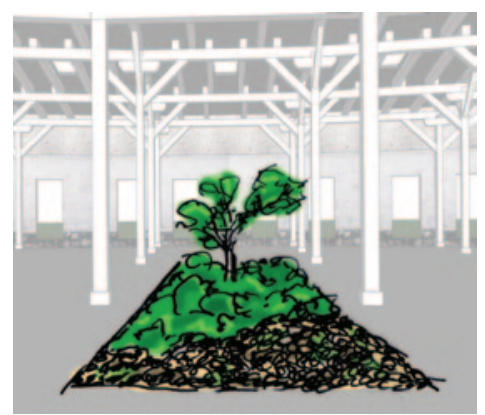

Figure H5 
In regards to my design, the metatextual example is ideal because it not only references the original pit but also creates a visual connection with the chiseled concrete pits I have created in the museum. The stepped design feature of the pit also allows for gatherings and interactions. Its central location and radial axis, that aligns with the turntable, makes stall 8 an ideal location for the main entrance discussed in figure $\mathbf{P} 4 \mathbf{b}$. Once through the entrance visitors will be able to interact, shop, and eat in this central portion with the option to move to the museum to the North or to the theatre to the South. 

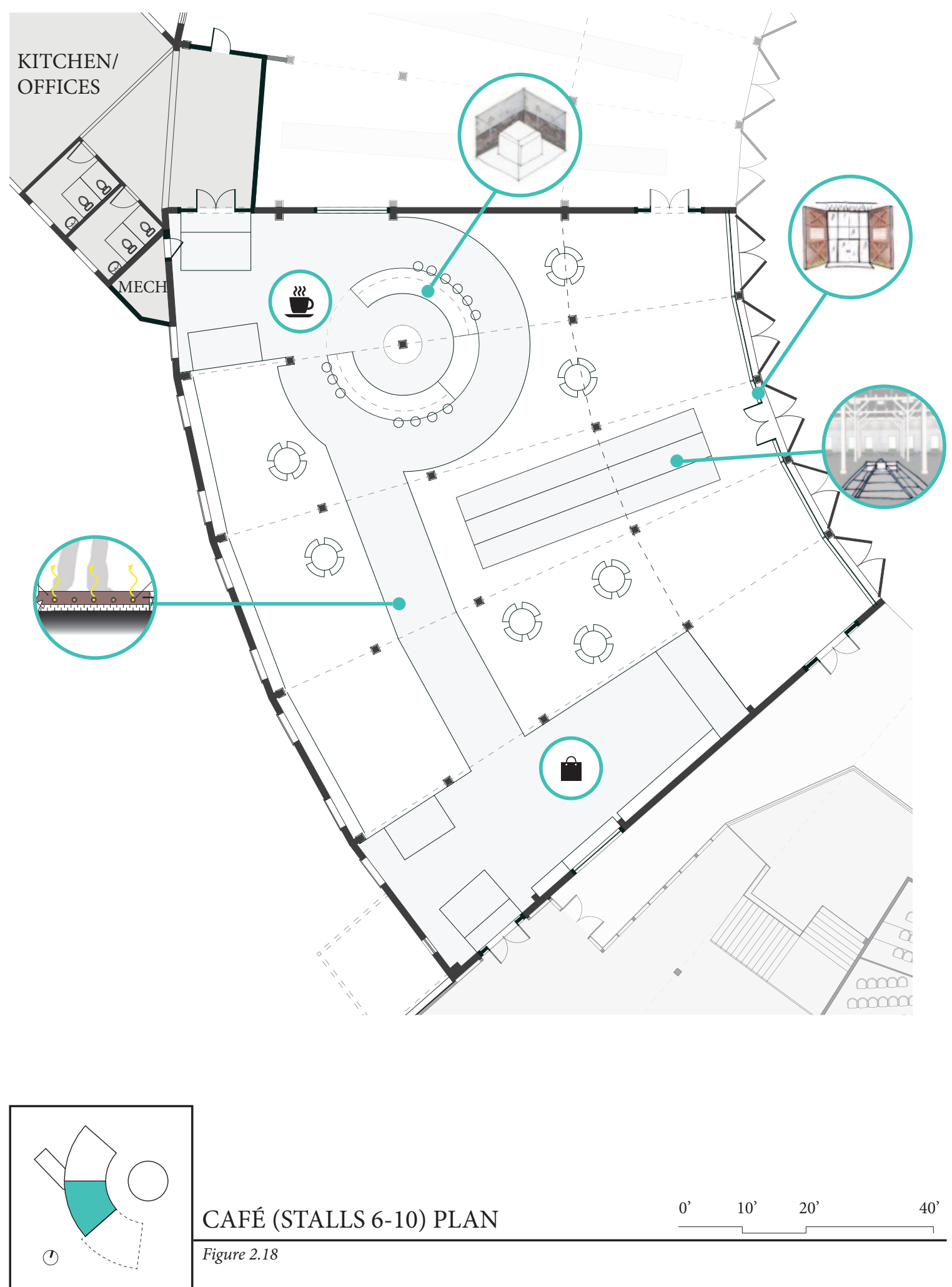

CAFÉ (STALLS 6-10) PLAN

\begin{tabular}{lll}
$0^{\prime}$ & $10^{\prime} \quad 20^{\prime}$ \\
\hline
\end{tabular}

40 Figure 2.18 

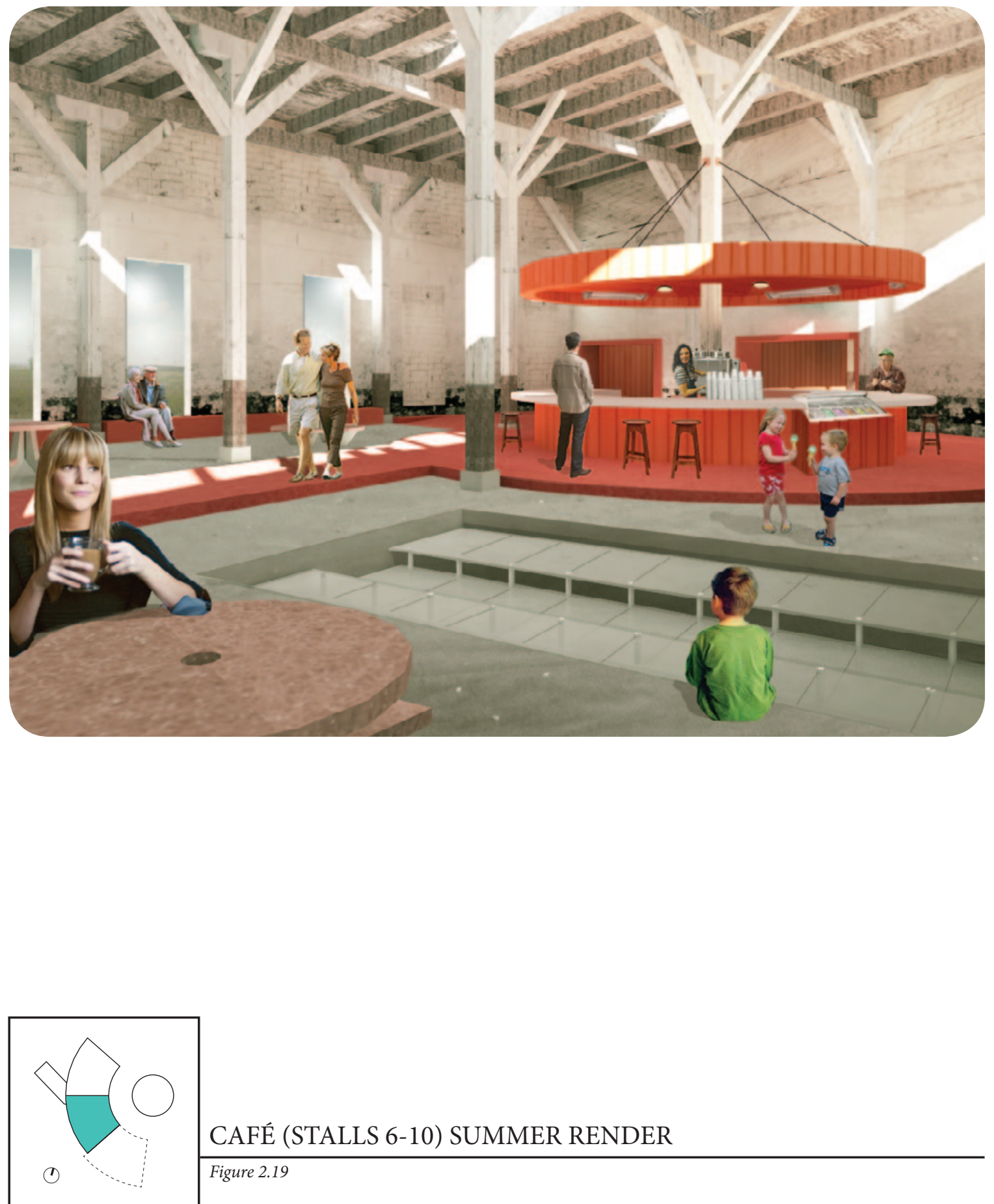

CAFÉ (STALLS 6-10) SUMMER RENDER

Figure 2.19 

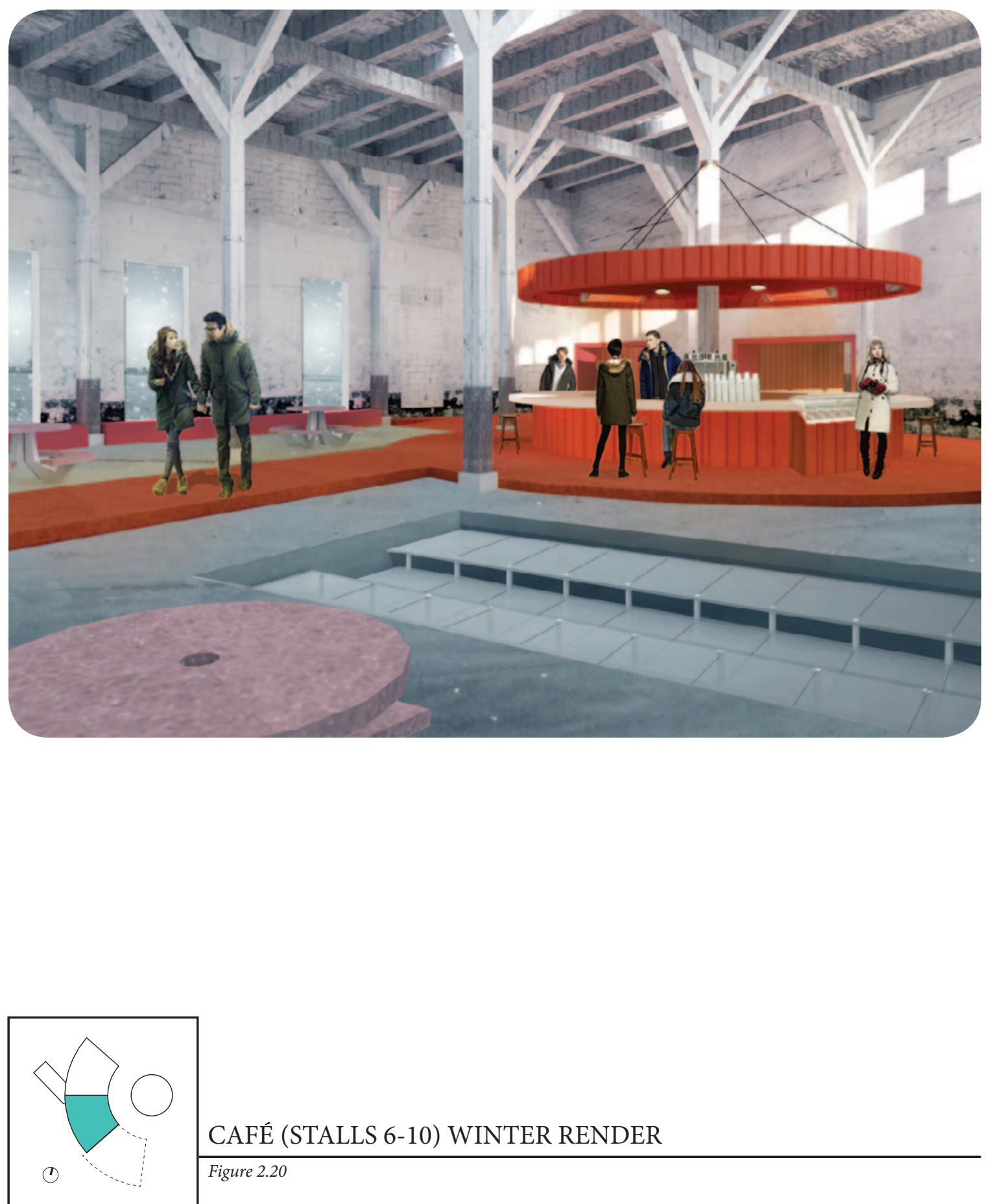

CAFÉ (STALLS 6-10) WINTER RENDER

Figure 2.20 


\section{THE THEATRE}

The final program is the theatre, which will consist of new construction. Referring to the transtextual exercise in form, the metatextual example (figure M1) references the demolished stalls 11-15. From my experience of visiting the Roundhouse in 2011 (when stalls 11-15 were partially standing) and in 2013 (when stalls 11-15 were completely demolished), it is important for me to regenerate the spatial enclosure created by those 5 stalls along the East elevation. The curvature of the Roundhouse and the old 15-stall elevation creates a sense of protection and support while outside around the turntable and looking into the rail yards. Since the demolition of stalls 11-15, the East elevation has been reduced by a third and is noticeably and experientially less. Due to the fact that this portion of the building has been demolished it will require new construction and therefore lends itself to the theatre program.

I took two primary approaches when determining the form of the new theatre addition: a metatextual and a hypertextual one. The metatextual approach took the philosophy of function follows form since the demolished stalls predetermined the form. The hypertextual approach did the reverse, where the form follows the function. This allowed experimentation through form related to the theatrical program. To explain further, while the metatextual forms followed the plan of the demolished stalls, the hypertextual forms contrasted the curvature and led to the theatre as its own object placed within the plan of the demolished stalls. Some of the experimentation led to the creation of a joint that connected the formal object to the existing Roundhouse, as opposed to a mere formal extrusion. Another hypertextual aspect, which was inspired by the rising seats and balcony of the theatre, led to a cantilever façade. While aesthetically I felt it was important to regenerate the formal features of the demolished stalls (metatextual), the hypertextual exercise freed me from the confines of what the Roundhouse was and allowed me to 
explore ideas that may not have been possible through a single exploratory exercise. As a result the theatre form evolved from a hybridization of the metatextual and hypertextual exercises.
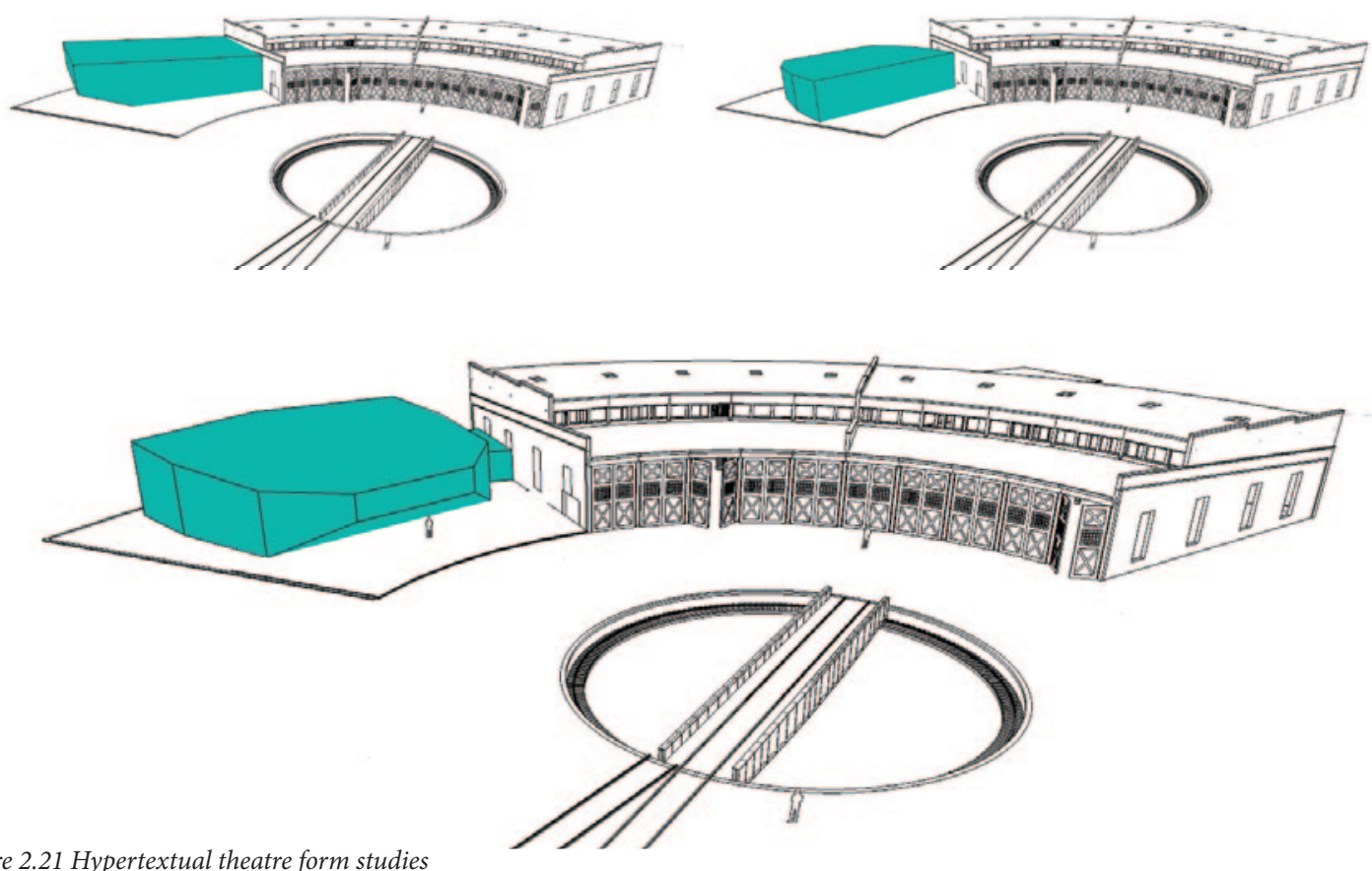

Figure 2.21 Hypertextual theatre form studies
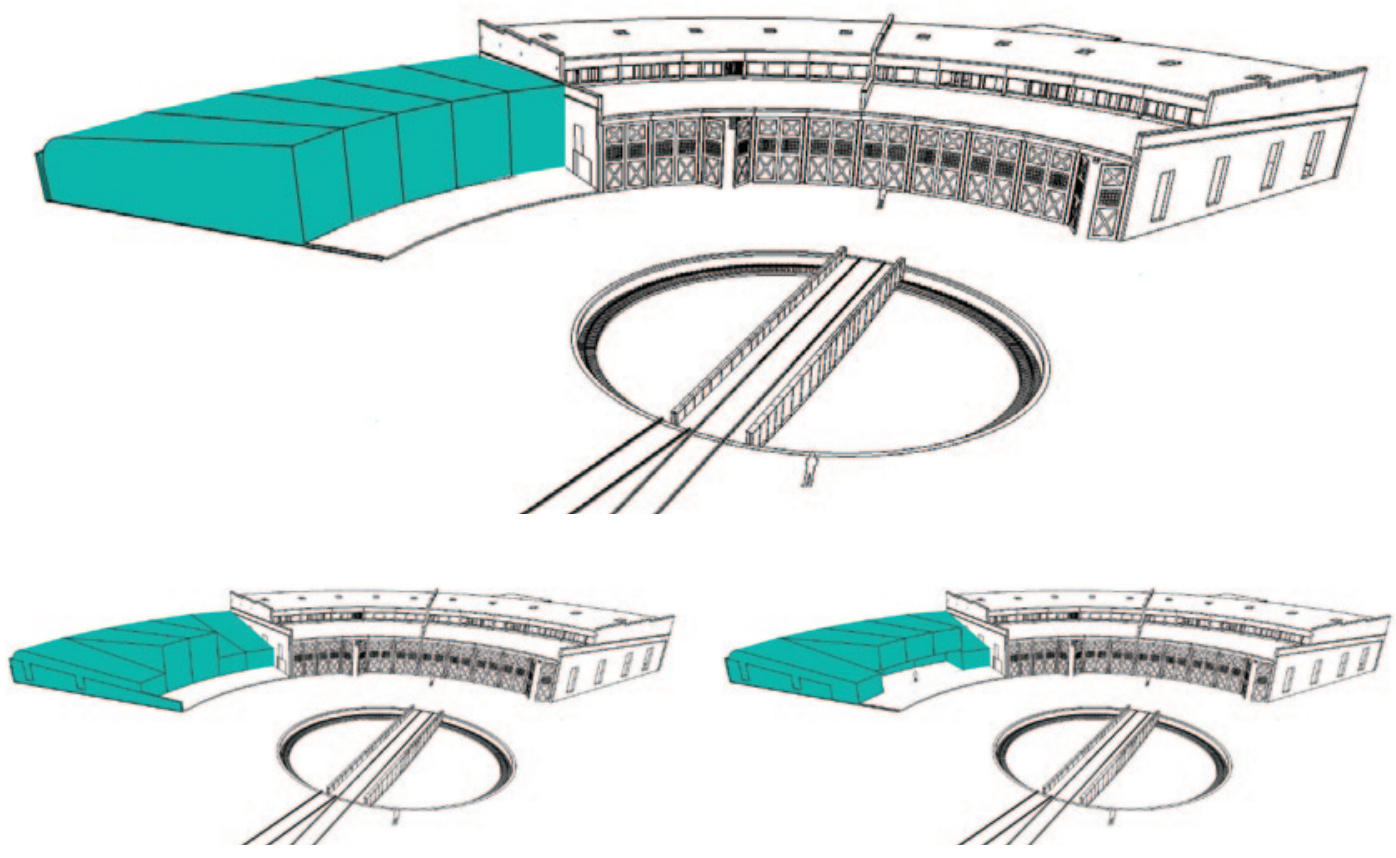

Figure 2.22 Metatextual theatre form studies 

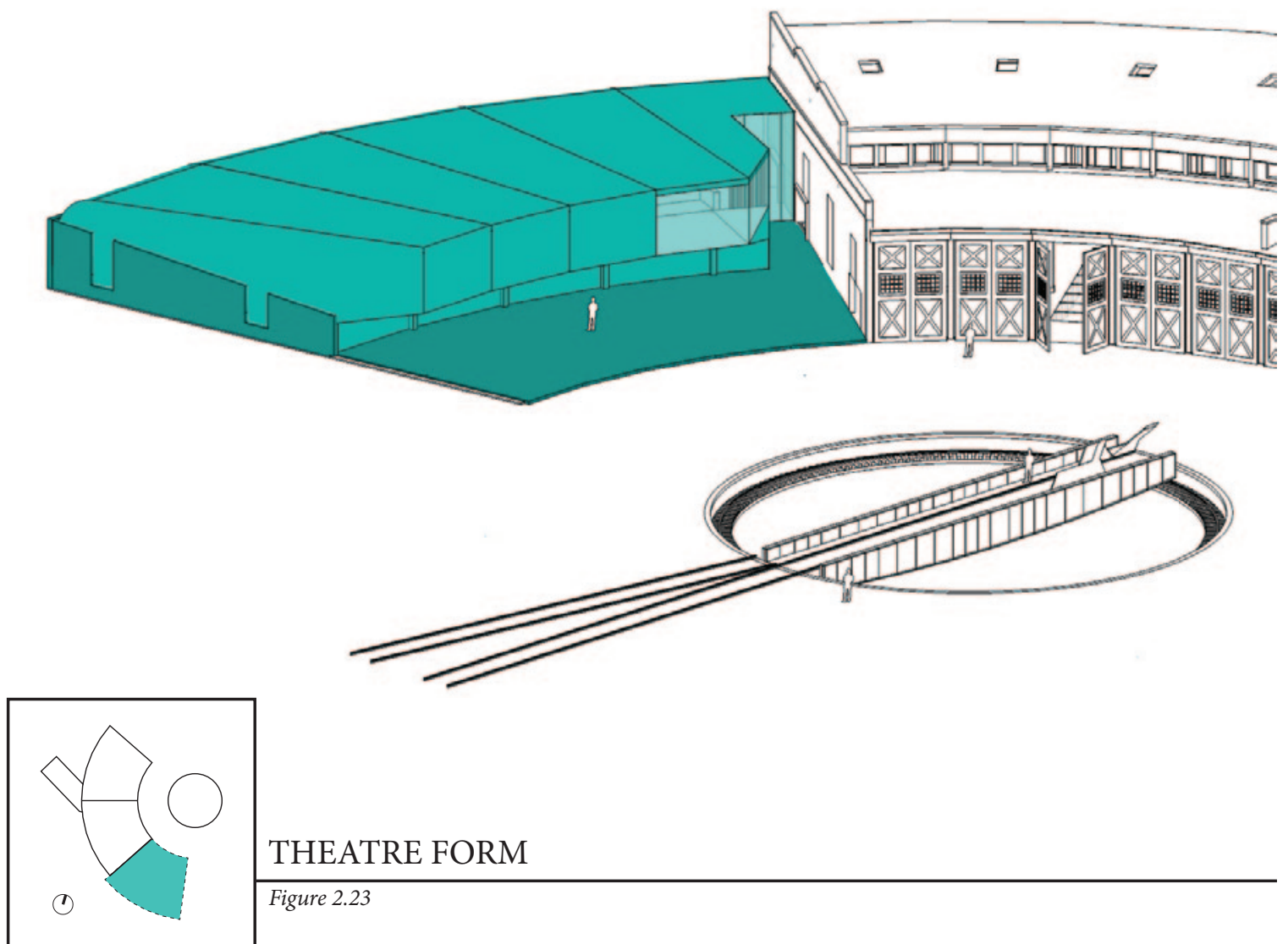

For the most part the theatre form follows the footprint of what was. The inner radial façade, however, is not in line with the existing roundhouse façade. Instead it is held back in alignment with what was the first row of columns. This creates an outdoor space defined by the exposed Southern wall of the roundhouse and material paving in the remaining footprint (materials will be discussed later). Since the inner radial elevation is also cantilevered, it meets the ground even further back to increase this exterior space as well as provide partial cover. This defines the space and allows for exterior gatherings, celebrations, and performances. By holding the elevation back it helps define the existing Roundhouse as the primary subject. While this façade's dimensionality may contrast with the seemingly flatness of the existing elevation, it also metatextually references the stalls 11-15’s partial collapse which I experienced in 2011 (see figure 4.1). 
In addition to the metatextual features, the hypertextual exercise influenced the joint between the theatre and the existing Roundhouse. The joint allows the exterior of the South elevation to remain visible. This wall represents the barrier between the 1913 original ten stalls and the 1919 addition. The wall is a rich historical record: the original 1913 windows have been filled with brick when the 1919 addition was added, holes mark where the 1919 addition's joists connected with the wall, the brick band along the top was added in 1943 when the roof was raised and finally it contain openings created by the cattle auction owners. This wall is the only element through which all the roundhouse's historical morphology can be read. Not only does the joint allow this record to remain visible, it also brings visitors face to face with the wall since the entrance to the theatre lobby is through the narrow passage along the wall. This Southern elevation is a prominent feature of the lobby as most of the areas that look towards it are glass curtain walls. While formally the joint originated through a hypertextual approach, the development in its framing, preservation, and directing movement along the wall are all paratextual elements. 


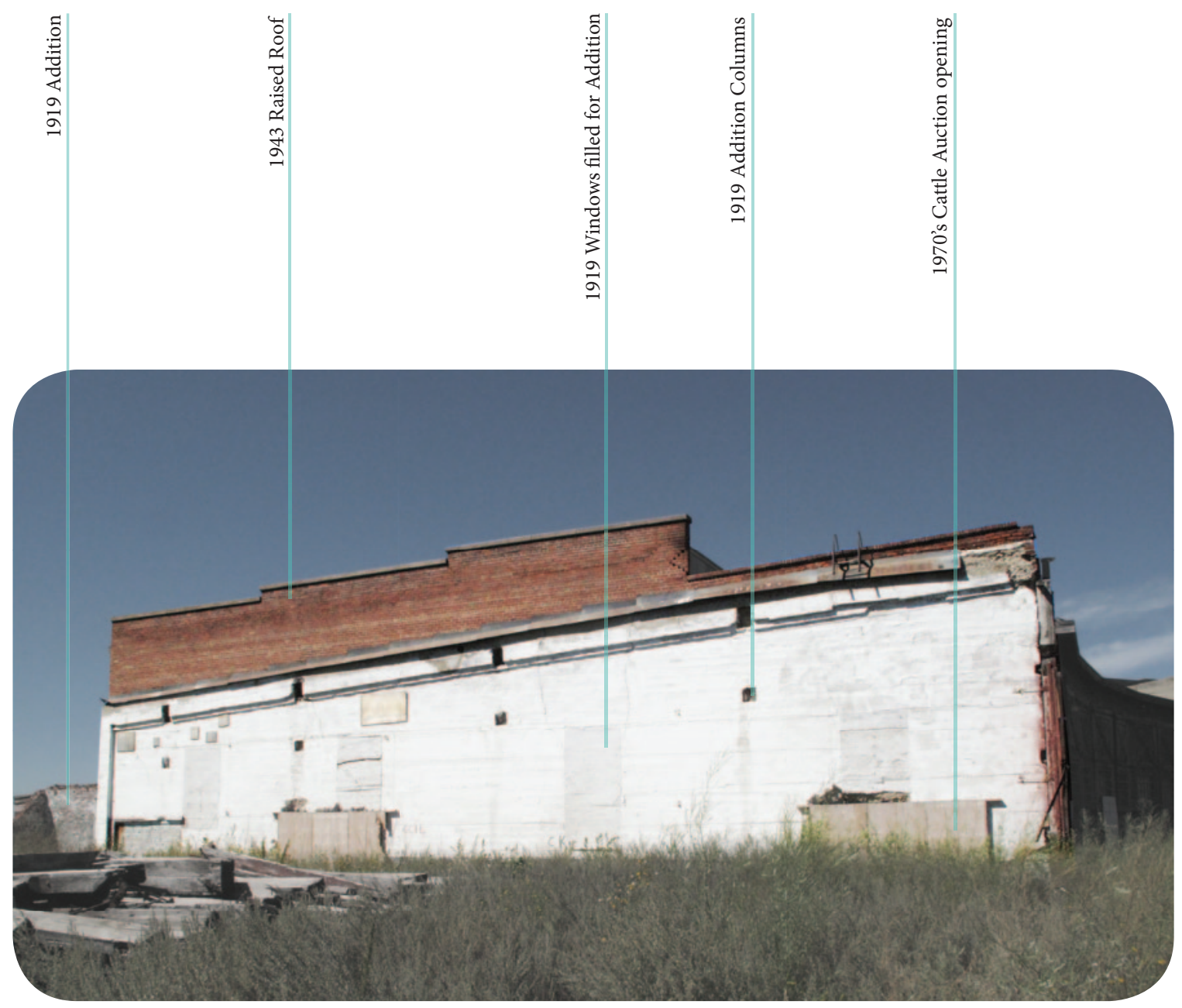

Figure 2.24 Roundhouse South Wall 

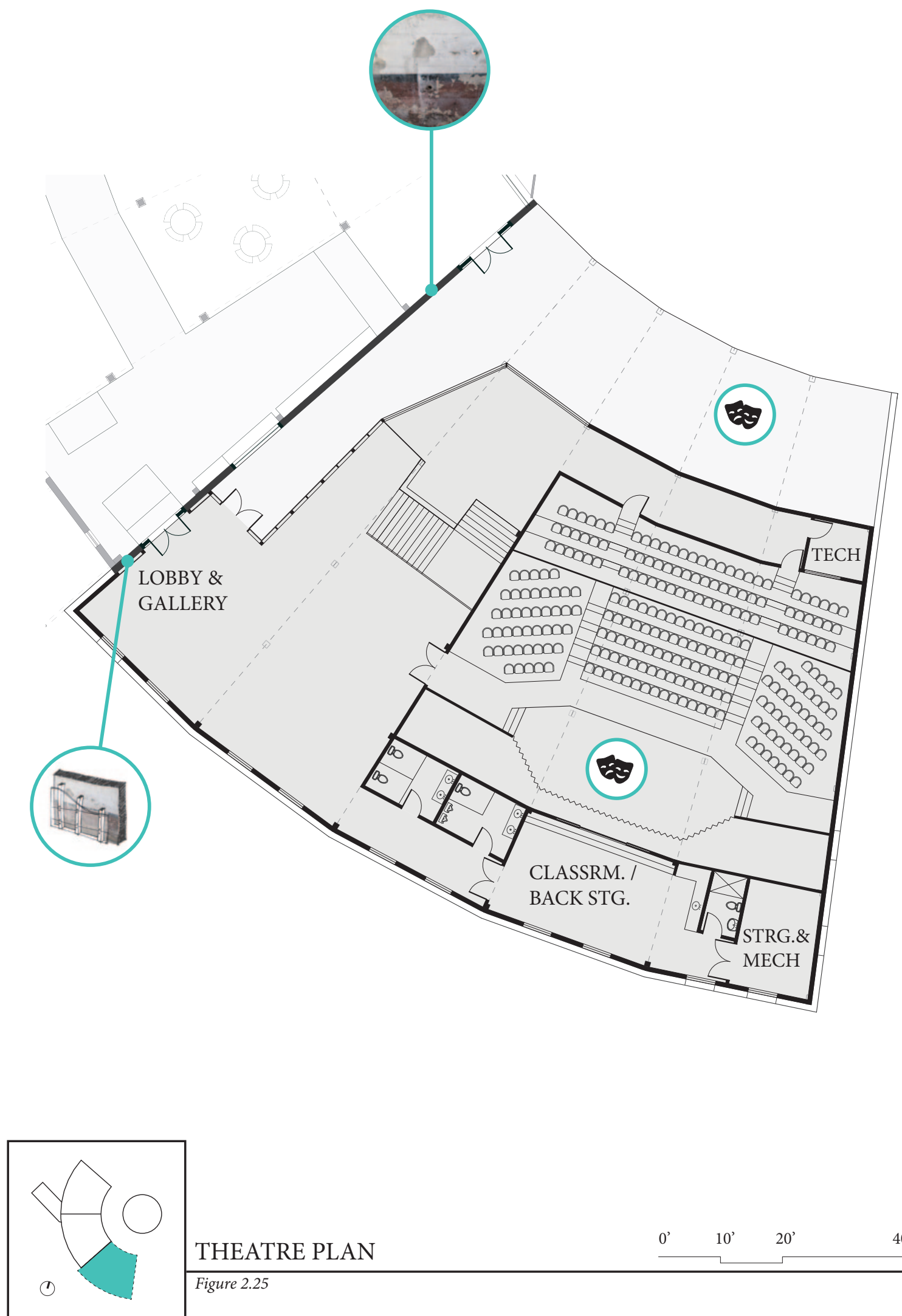

THEATRE PLAN

$\begin{array}{lll}0^{\prime} & 10^{\prime} \quad 20^{\prime}\end{array}$

40

Figure 2.25 

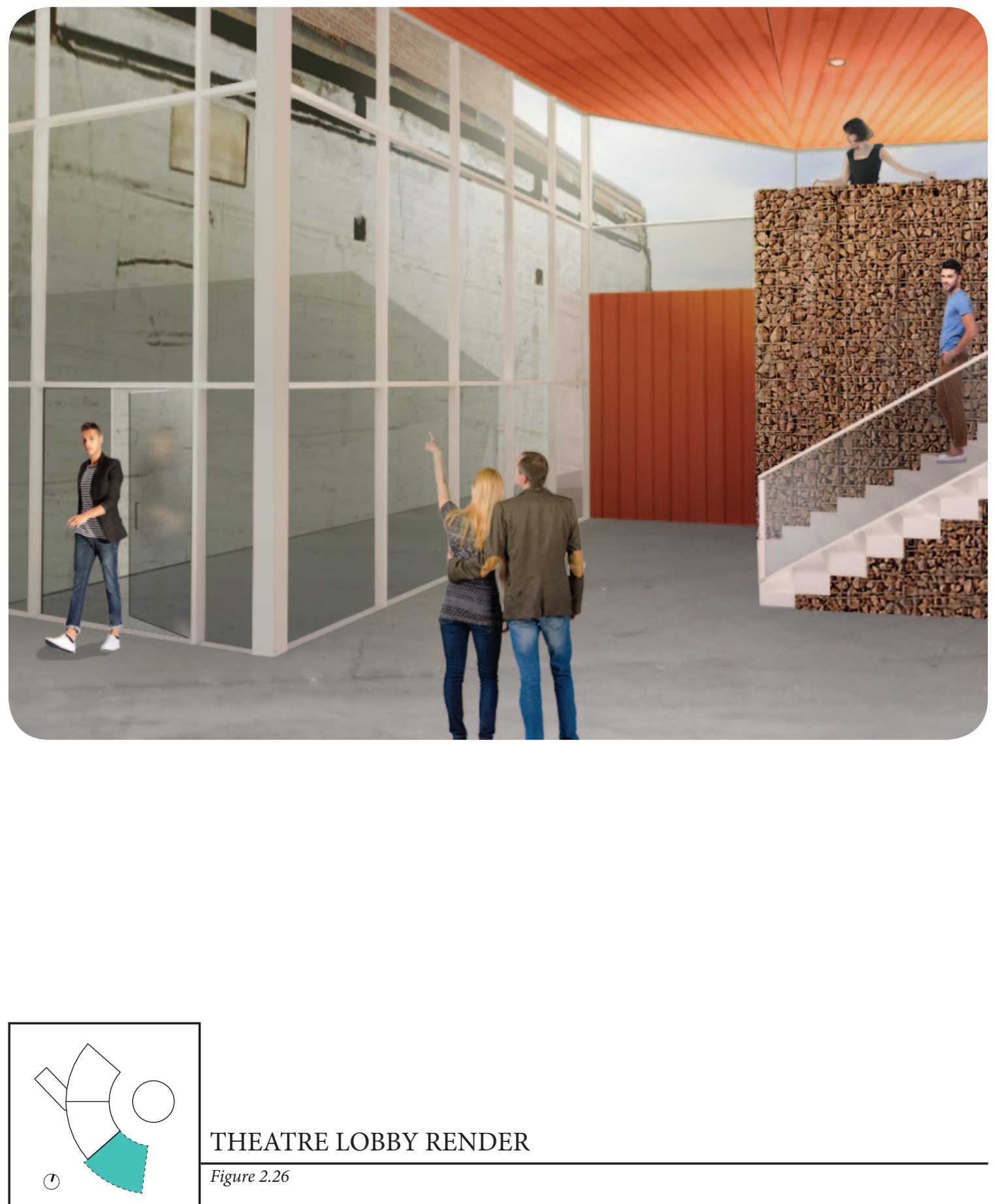

THEATRE LOBBY RENDER

Figure 2.26 

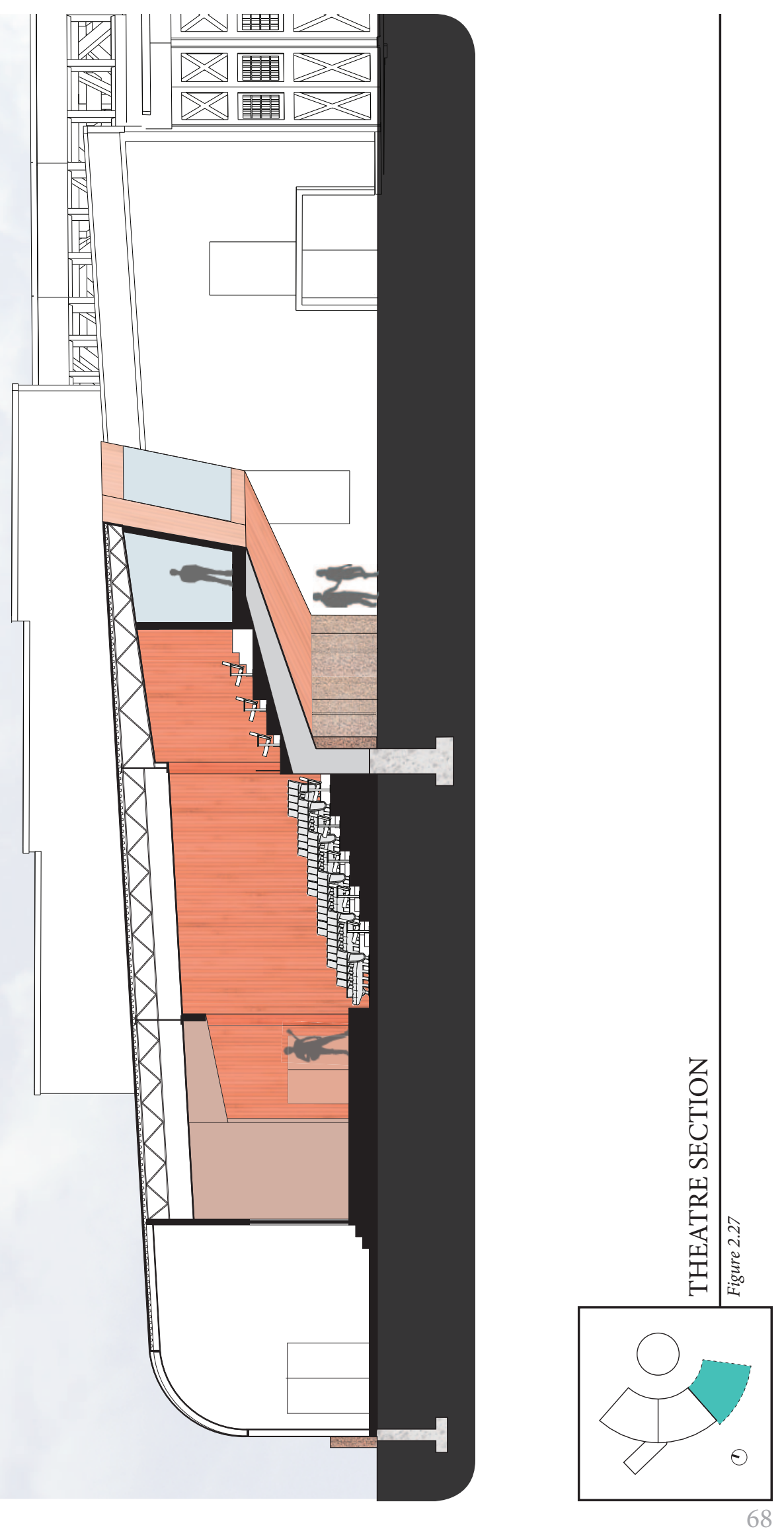

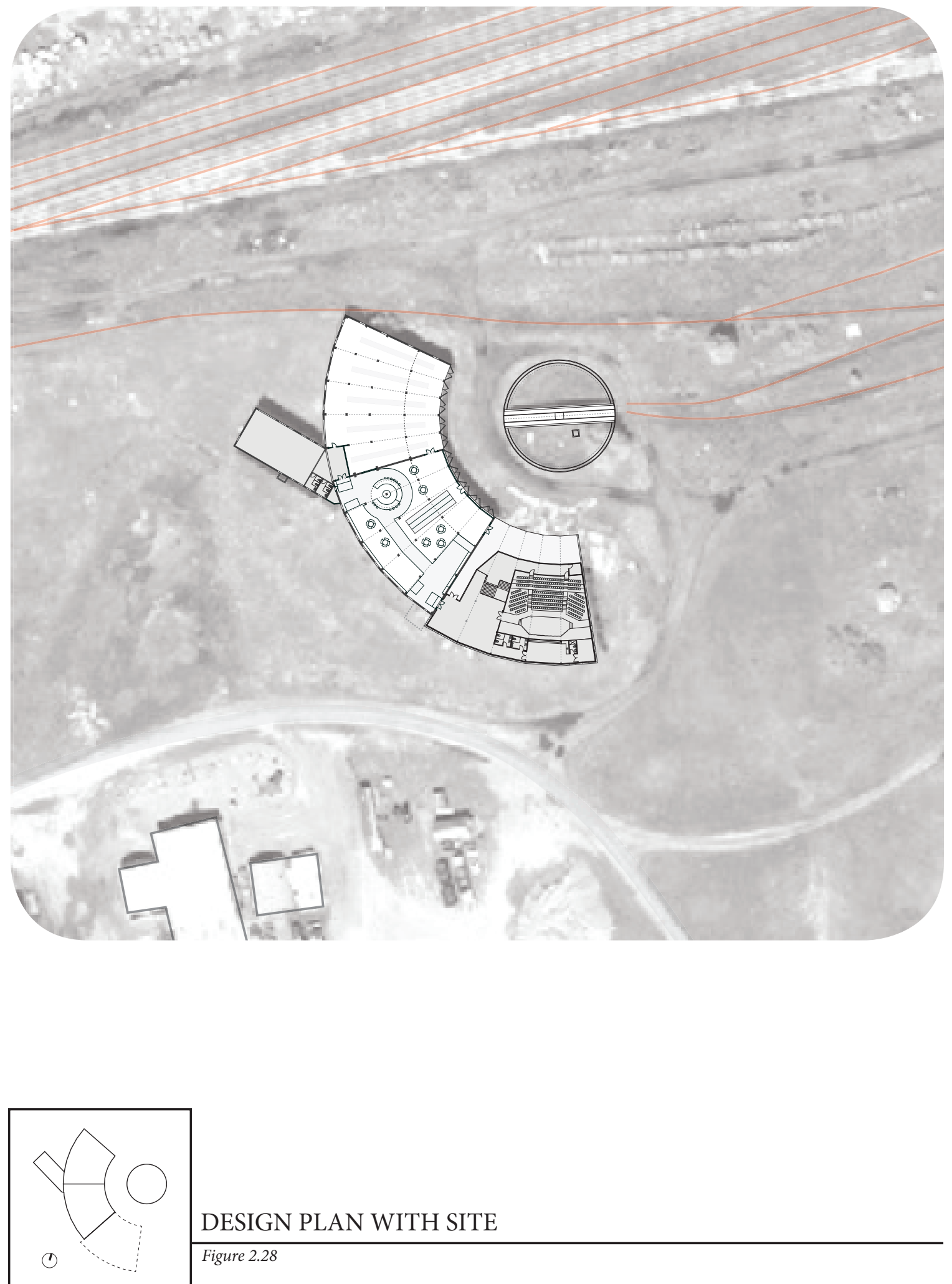

DESIGN PLAN WITH SITE

Figure 2.28 


\section{THE TURNTABLE AND SITE}

The turntable presents an interesting challenge. As the crown jewel of the site, the turntable's historical value is intrinsically linked with remaining as it is/was as opposed to becoming something new. Through conversations with Beaudoin, and my research, it became evident that the historical identity and functional operation of the turntable is important to local railroad historians and enthusiasts. The Hanna Roundhouse Society intends to replace the broken mechanisms, which will allow the turntable to rotate once again. The challenge in the design and use of the turntable is finding a new reason for it to rotate. Since the turntable's original function was to direct the locomotives into the appropriate stall, I would like to reuse this directionality for tourists. For special events/ activities taking place at the Roundhouse (be it a farmers market, wedding, theatrical performance, etc.) the turntable will be aligned with the chosen entrance of that event.

Visitors will park in the designated zone which stretches from the South-East corner of the theatre all the way to the ruins of the water tower at the East end of the field. Parking close to the Roundhouse allows for easy access for staff, handicapped and drop-off visitors. Parking further east places the visitors in the middle of the field in order to promote exploration of the site and to immerse the visitors in the historical landscape from the moment they get out of their vehicle. This approach westward from the parking lot, along the rail lines, aligns visitors with the turntable as they approach. This approach mimics the historical approach of the trains. The parking lot will be gravel, which unlike solid paving, provides a sense of impermanence that fits with the ruinous nature of the historical field. This will also allow for nature to penetrate the parking surface. 


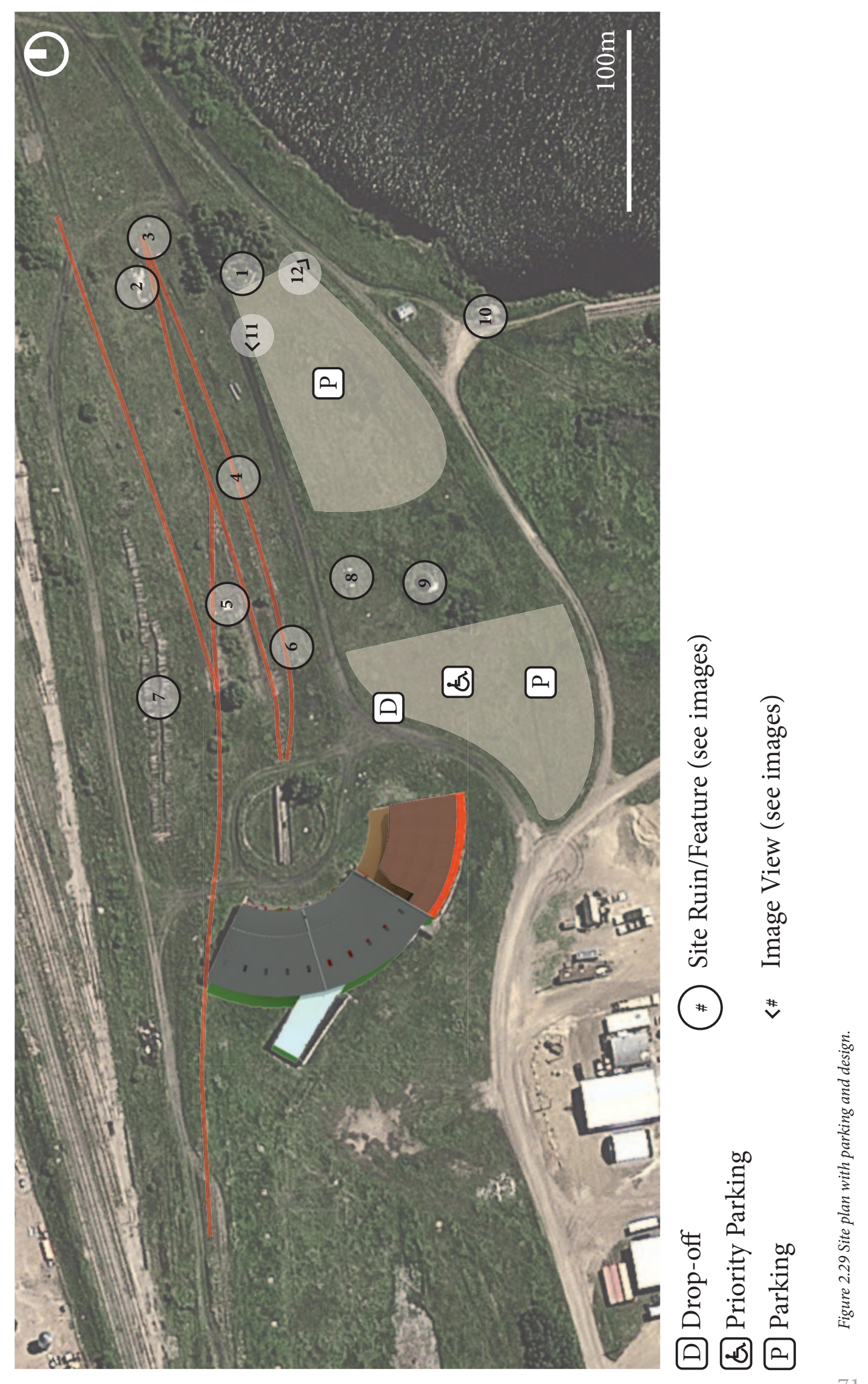



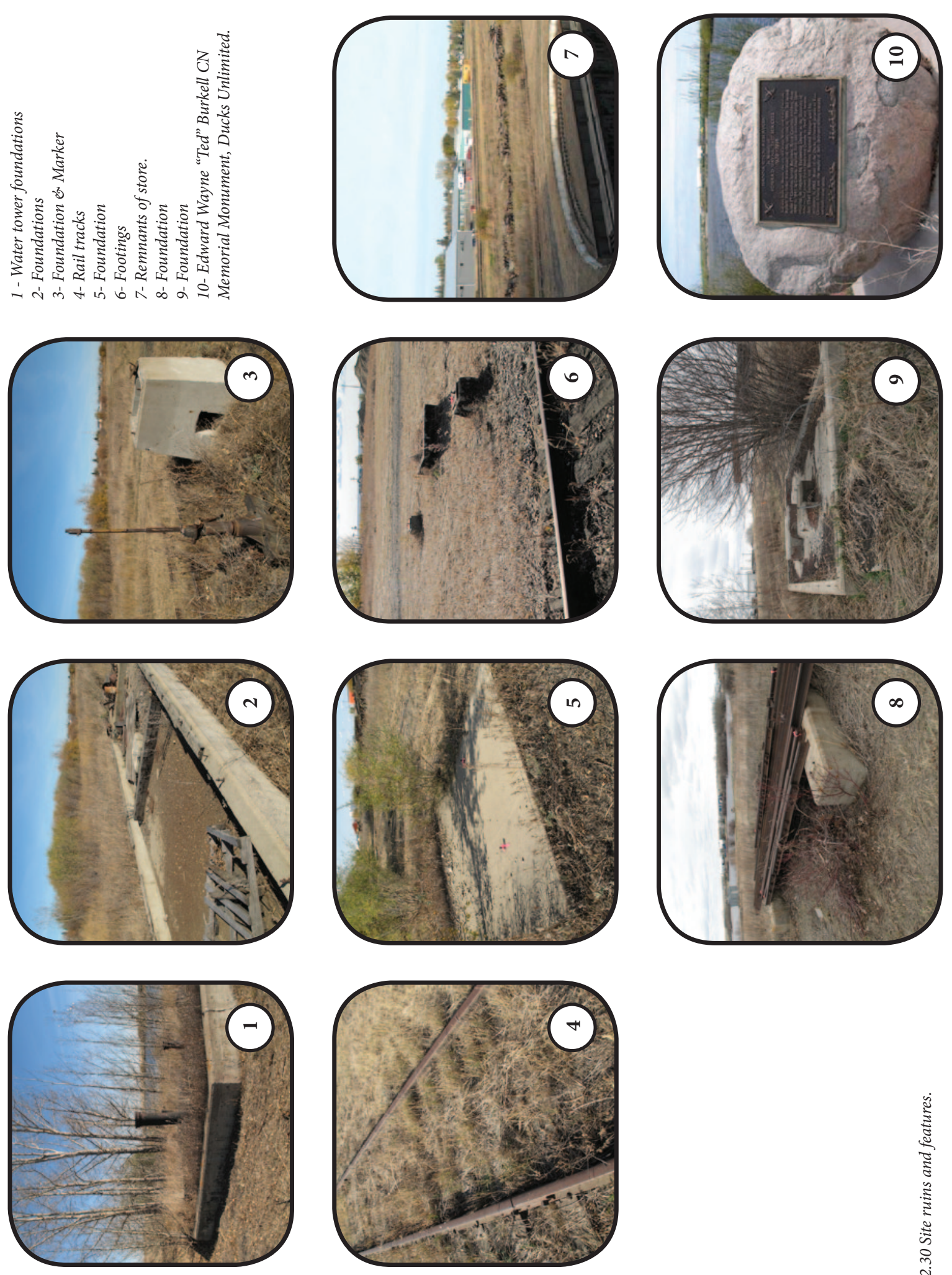


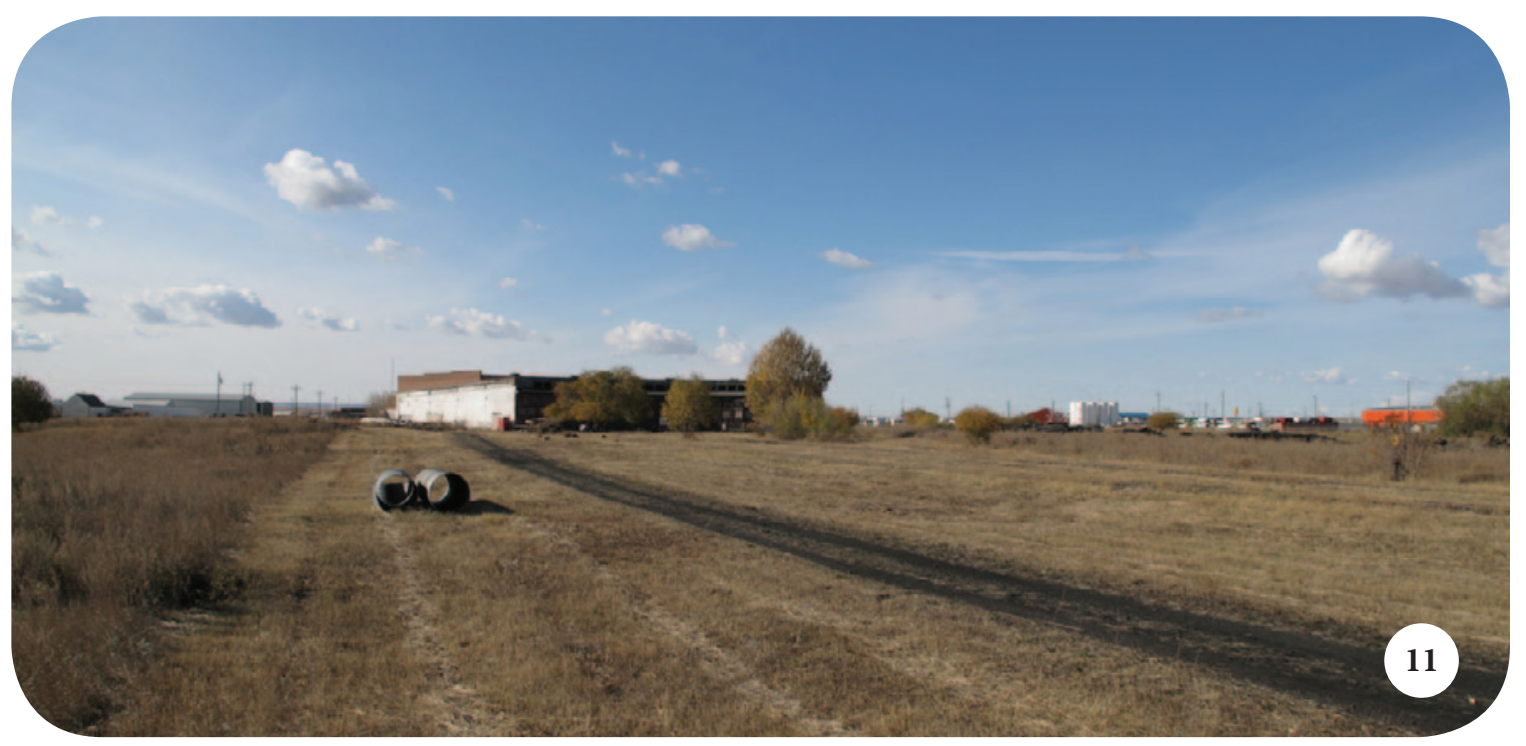

Figure 2.31 View from the proposed parking towards the Roundhouse.

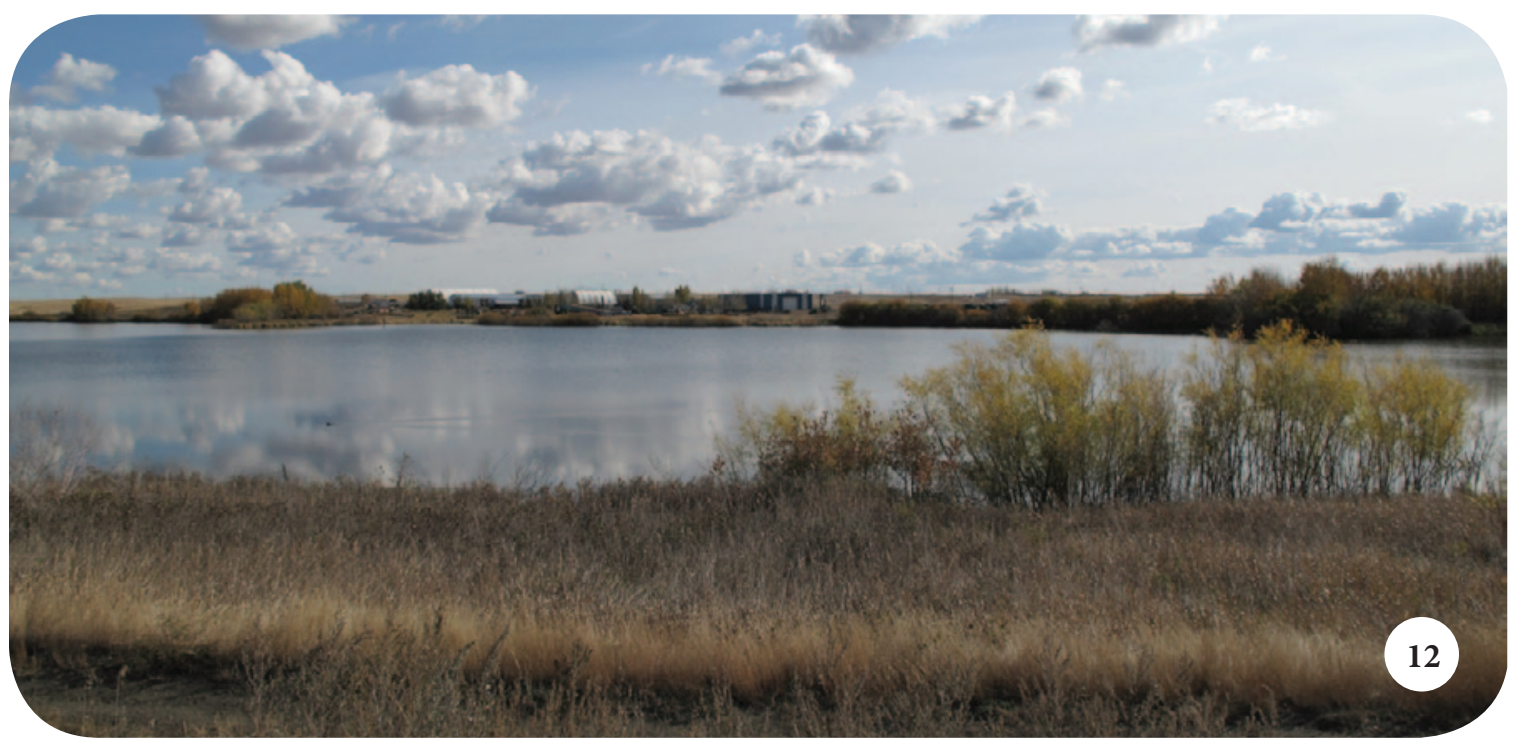

Figure 2.32 View from proposed parking towards the CN Reservoir. 
Another important aspect of the turntable is the fact that the 15 rail lines leading from the turntable to the stalls have been removed. This is a lost text that I would like to metatextually reference. While the decision to reference these removed rail lines is metatextual, I approached how I reference them in two ways: metatextually and paratextually. I did not explore hypertextuality as I felt that there is no hypotext to be transformed.

Figure E6 is a representation of the rail condition in 1943. The 15 rail lines leading from the turntable to the Roundhouse have since been removed.

Figure M6 is a metatextual example where the physical placement of each rail line is referenced. This example proposes a paved surface (stone or similar) with a small gap where each rail line once was. The void is minimal, but is large enough to allow the natural grasses to grow up above the paving and materially reference the loss of the rail lines.

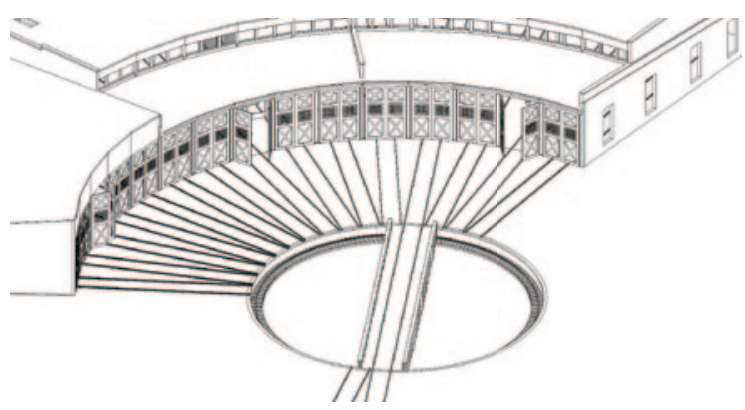

Figure E6

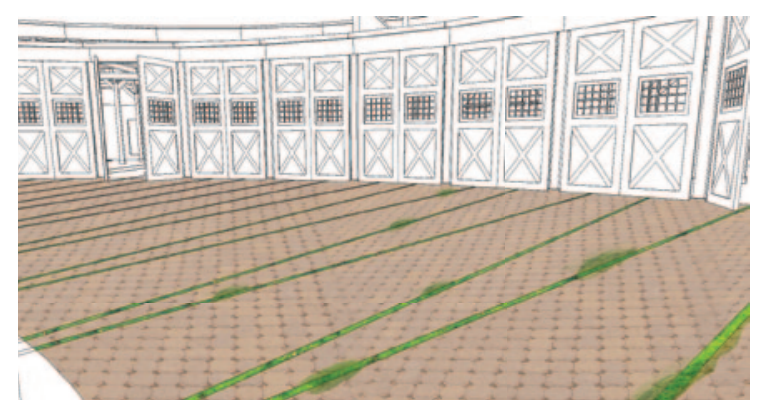

Figure M6 
Figure P6 is a paratextual example. Based off of the framing nature of paratextuality, this example involves an anamorphic perspectival sculpture at one end of the turntable. When viewed from the opposite end of the turntable, the perspective creates the illusion of the rail lines continuing in that one direction. In that moment it recreates a fleeting memory of the rail lines. When viewed up close this sculpture will act as an information panel on the turntable and site.
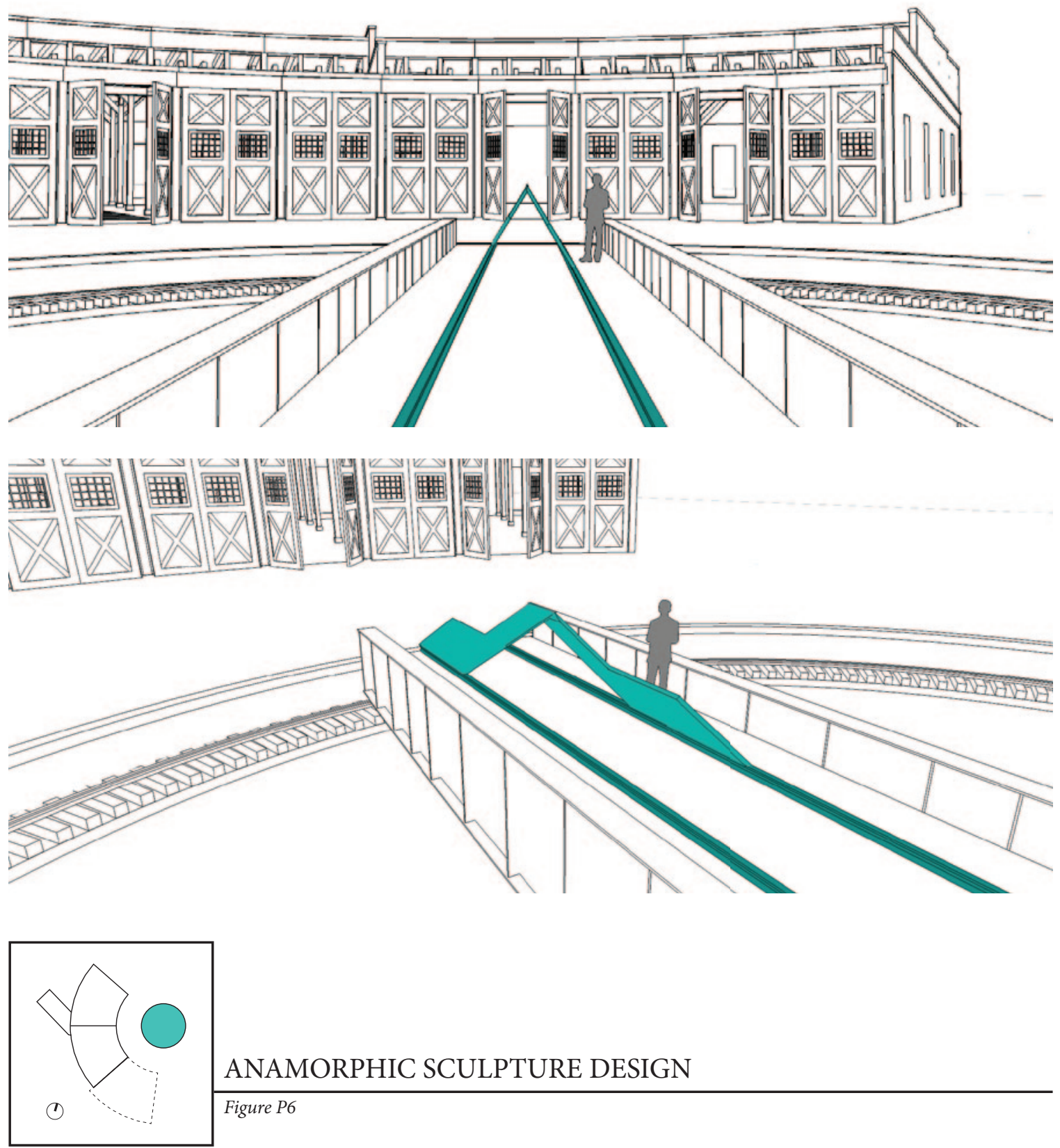

ANAMORPHIC SCULPTURE DESIGN

Figure P6 

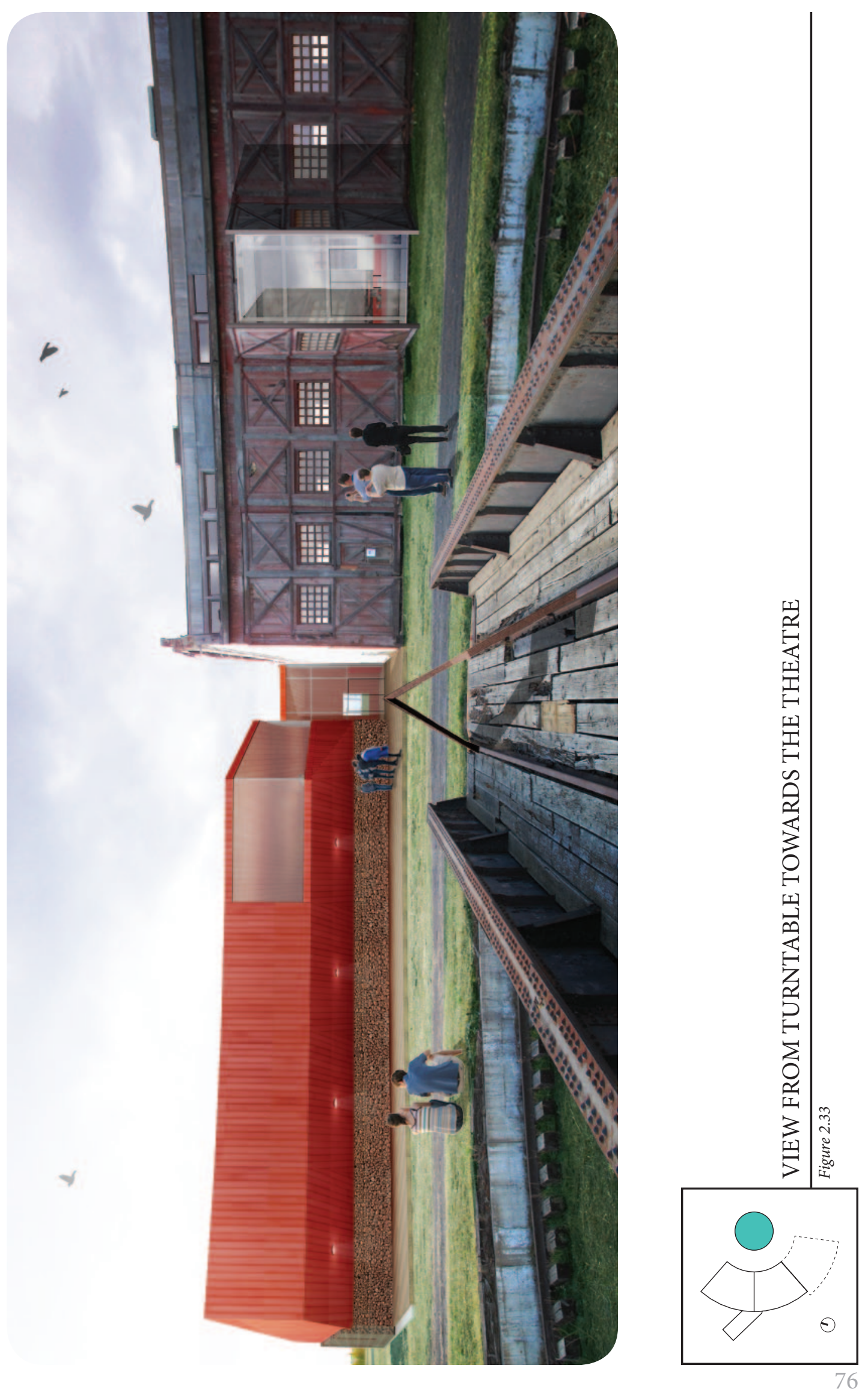
Due to the fact that the turntable will be used to align visitors with a particular entrance, figure $\mathbf{P 6}$ provides another degree of direction. The sculptural element being placed at one end creates a directional point; a hierarchy in an otherwise equalized system. The sculptures perspectival recreation of the rail lines also adds another level of importance to the chosen entrance for a particular activity since that will be the only direction in which the rail lines are recreated. The materiality of the sculpture would be corten steel because the colour and appearance would be similar to that of the rails and it would rust over time to reveal its age.

\section{MATERIALITY}

It is important that the materiality of the design reflects the existing palette and yet be readable as a new textual addition. The following is a material palette that has been transtextually composed:

Figure I7 is an intextual material example. After the demolition of stalls 11-15, the bricks and heavy timber were piled up on site. These materials are therefore readily available for spolia and reuse.

Figure P7 is an example of a paratextual material. Glass makes for a good paratextual example because of its transparency. It does not visually divide space and it is often associated with preservation via encapsulation.

Figure M7 is a metatextual color as opposed to a material. In the case of the roundhouse, red seems to be the only color in what is otherwise a very monochromatic scale. The rust of the rail lines and turntable (A), the painted wooden doors (B) and interior walls (C), and the bricks (D) are all shades of red, which would therefore be metatextually 
Figure I7
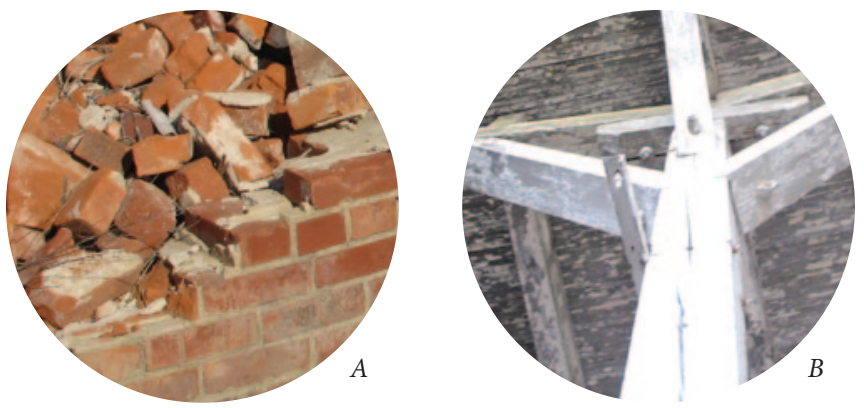

Figure P7

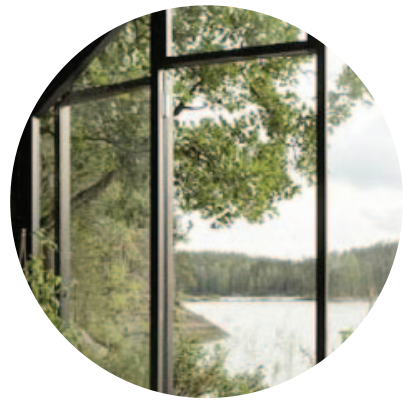

Figure M7

Figure H7
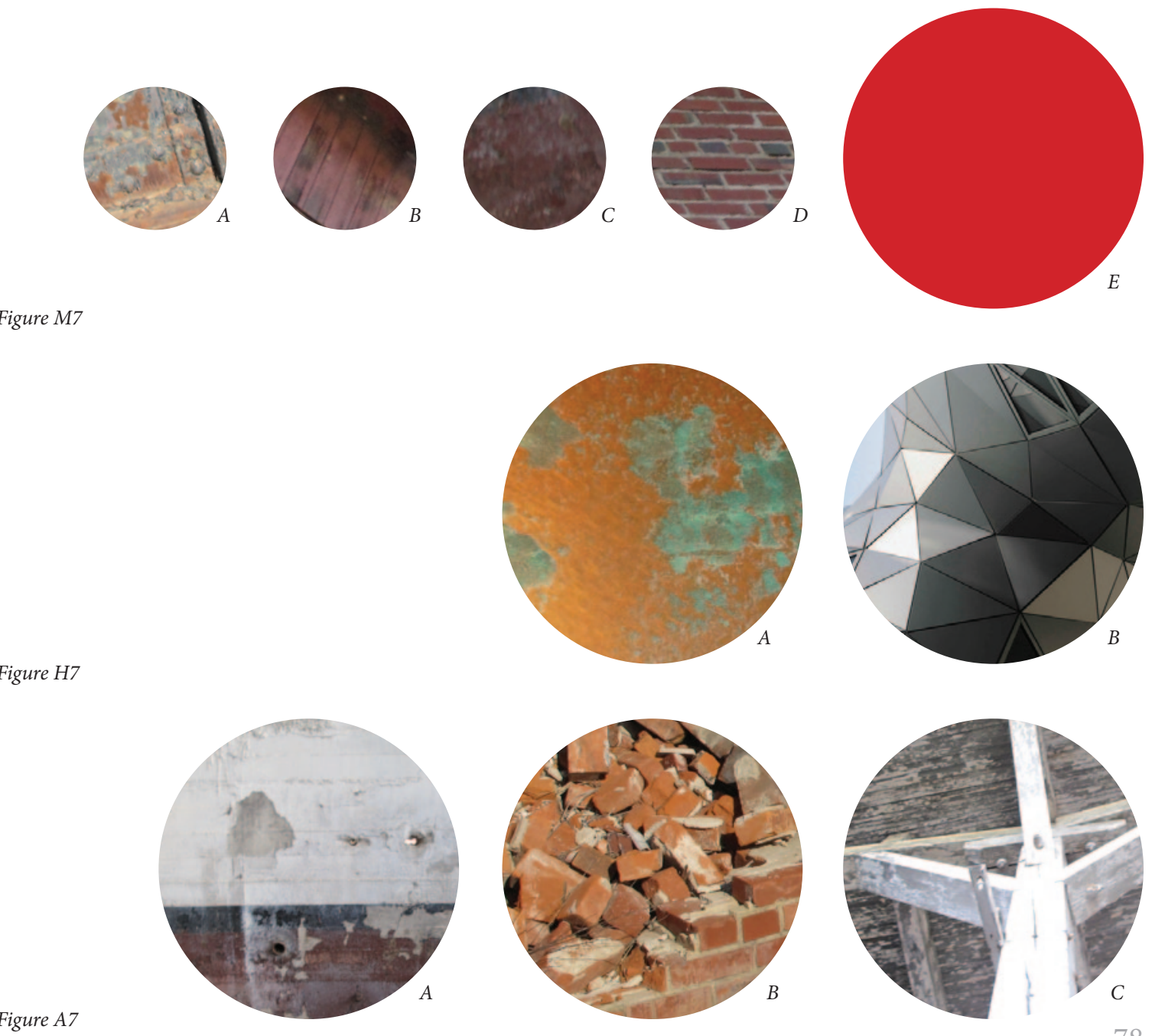
referenced, in the new construction if it too was red. Since this example is a color, it can be applied to a variety of materials.

Figure H7 is a hypertextual example. Material A is itself transformative; it is copper, which, like corten steel and other weathering metals, corrodes and changes color. Material B is an aluminum panel system. Neither the copper nor the panel system, currently exist as part of the roundhouse and site and therefore their introduction as a material choice would be additive and transformative.

Figure A7 is an architextual example because it includes materials that currently compose the roundhouse and site. This includes concrete, brick, heavy timber and wood.

It is important to note that the material relations explored above are in regards to the existing material palette (the same as figure A7). The way in which the materials are used could allow for overlap between the transtextual terms. For example, I am interested in reusing the bricks that remain from the demolished stalls 11-15 (intertext). I would like to reuse them in the walls of the theatre and as part of the feature staircase in the lobby. Due to the fractured nature of the bricks I would like to use them as filling for a gabion cladding system (cages 9"-12" deep). ${ }^{17}$ The use of the gabion cage to use the rubble as vertical cladding is paratextual. In addition to this, my decision to frame them in the gabion wall as fractures metatextually references the demolishment of the stalls 11-15. Thus the reuse of the bricks as a gabion cladding is intertextual, paratextual and metatextual.

Since the brick rubble will not be sufficient as an entire cladding system for the theatre, the rest will be stained wood. Wood is an architextual material that is most visible along the East façade in the doors and frames. I would like to include the metatextual color red 
because of its relationship to existing features and stain the wood red (albeit a different more vibrant

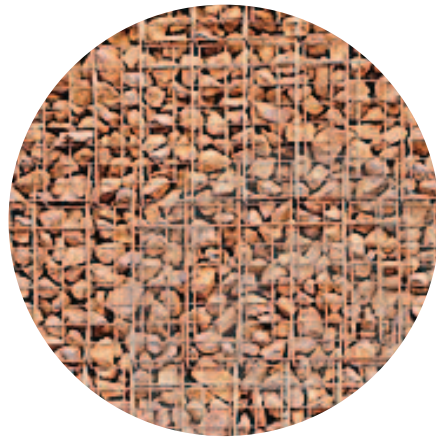

Figure 2.34 Brick Gabion Wall

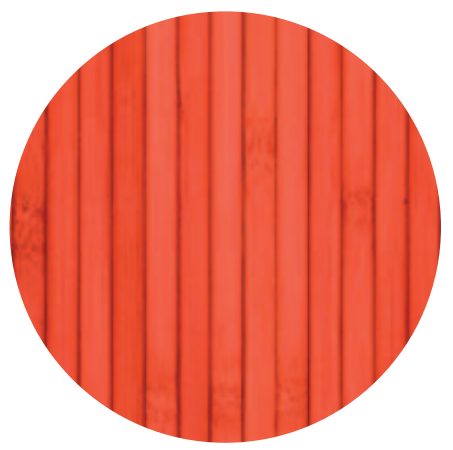

Figure 2.35 Red Stained Wood

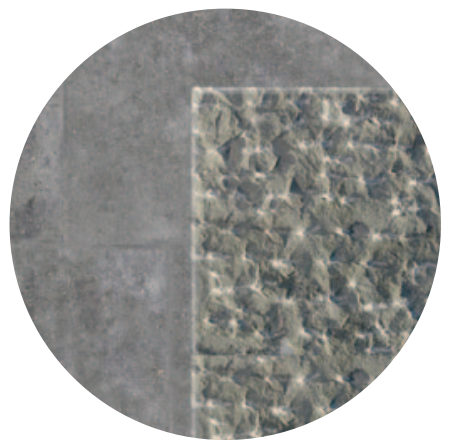

Figure 2.36 Concrete Chiseled Detail shade than the existing red wood). The existing wood façade cladding and doors consist of 2" wood members and in order to help differentiate the new wood I would increase that to 4 ". This new red stained wood cladding system would also be used on the café service bar in order to maintain the visual connection. The café path would be concrete due to the radiant heat tubes embedded within it. This concrete would include a red dye that would not only tie in with the café service bar but also symbolically represent the path as a heat source.

Unlike the theatre and café portions of the design, the museum will not have the colour red, as there are no new structures. I would, however, like to discuss further the material treatment of the concrete floor. As previously stated chiseling the surface of the existing concrete floor will identify the pits. This action also has multiple textual relationships. It is primarily metatextual since it is referencing the lost pits, but it also has paratextual undertones because of the chosen technique of referencing (chiseling). In regards to materiality though it is hypertextual since it is transforming an existing material. 


\section{CONCLUSION}

While adaptive reuse is an accepted and common practice, I believe the integration of transtextuality allows for a richer understanding of the meanings, consequences, and relationships between the new, old, and forgotten in built form. Transtextuality allows for a categorization and analysis of built relationships, which benefits both users (readers) and designers (authors). As readers of architectural records, transtextuality allows us to compare and contrast built relationships that have been combined through different periods of time. As authors, a transtextual exploration highlights the level of intervention in an existing text by examining the consequences of our actions.

The Hanna Roundhouse makes for a great case study because it has a foundational history that is valued within the community. By exploring the design transtextually, I was able to understand how my actions would influence the reading of the site after my intervention. Approaching a design detail according to the various transtextual terms identified new possibilities as well as clarified techniques that I was either in favour of or against. The transtextual paradigm strengthened the overall design intent that I subjectively had as the architect (author). The new elements of the design remain contemporary and do not aim to falsely suggest an alternative history. Instead the contemporary design is merely a modern chapter in an already long and varied historical record. 


\section{ENDNOTES}

Statistics Canada. 2011. 2011 Census Profile for Hanna, Alberta.

2 Town of Hanna $>\mid$ Visitors $>$ History $>$ A History of Hardship." Town of Hanna $>\mid$ Visitors $>$ History $>$ A

History of Hardship. http://www.hanna.ca/Visitors/History/AHistoryofHardship.aspx (accessed December 12, 2013).

3 Ibid.

4 Dorin, Patrick C. The Canadian National Railways'story. Seattle: Superior Publishing Company, 1975: 9.

5 Matthews, Ray A. Canadian National in the West Vol. 5. Calgary: British Railway Modellers of North America: 9.

6 "CNoR Strikes Water in Copious Quantities for Big Tanks", May 28, 1914, Hanna Herald, Hanna Archives. Email communications with Sandra Beaudoin, 2013.

Email communications with Laurie Armstrong, 2013.

Email communications with Sandra Beaudoin, 2013.

Williams Engineering, Structural Evaluation, 2010. Courtesy of Sandra Beaudoin.

Ibid.

Ibid.

Visit to Big Valley, Alberta by Author, 2013.

Hill, Jonathan. Weather architecture. London: Routledge, 2012: 273.

Could also be considered metatextual as it is influenced by the Archbishopric Museum of Hamar by Sverre Fehn.

"HLA.com." High Line Art. http://art.thehighline.org/project/spencerfinch/ (accessed March 27, 2014). Suggesting a similar gabion cladding that is used at the Ralph Klein Legacy Park in Calgary, Alberta. This wall system allows for an interior and exterior gabion cladding with insulation and structure in the centre. "Cladding." Gabion Wall Systems Ltd. http://www.gabionwallsystems.com/gabion_wall_systems_ltd_003. website (accessed April 1, 2014). 
APPENDICES 


\section{APPENDIX}

\section{ALTERNATIVE CAFÉ DESIGNS}

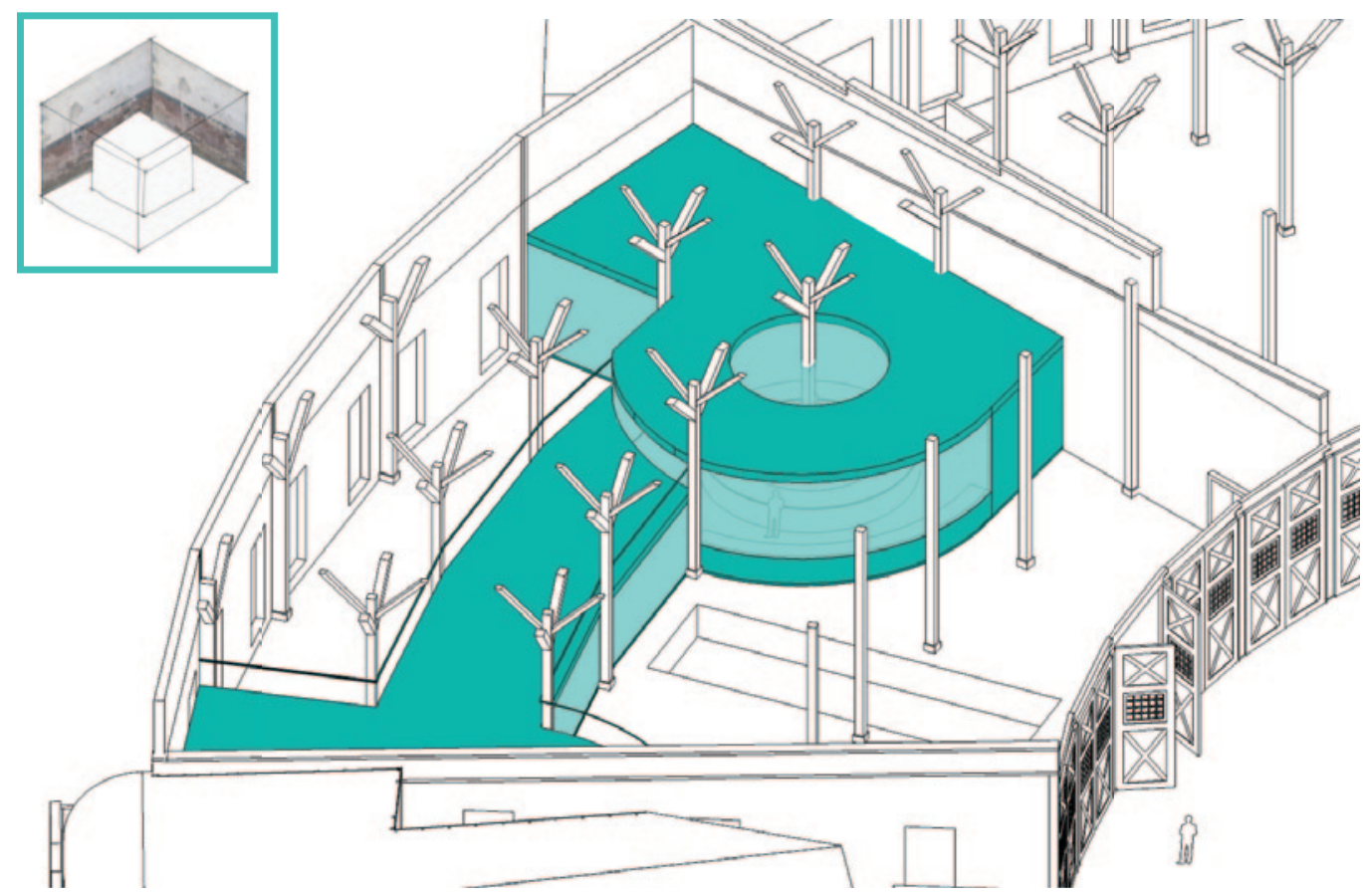

Figure 3.1 Café design A.

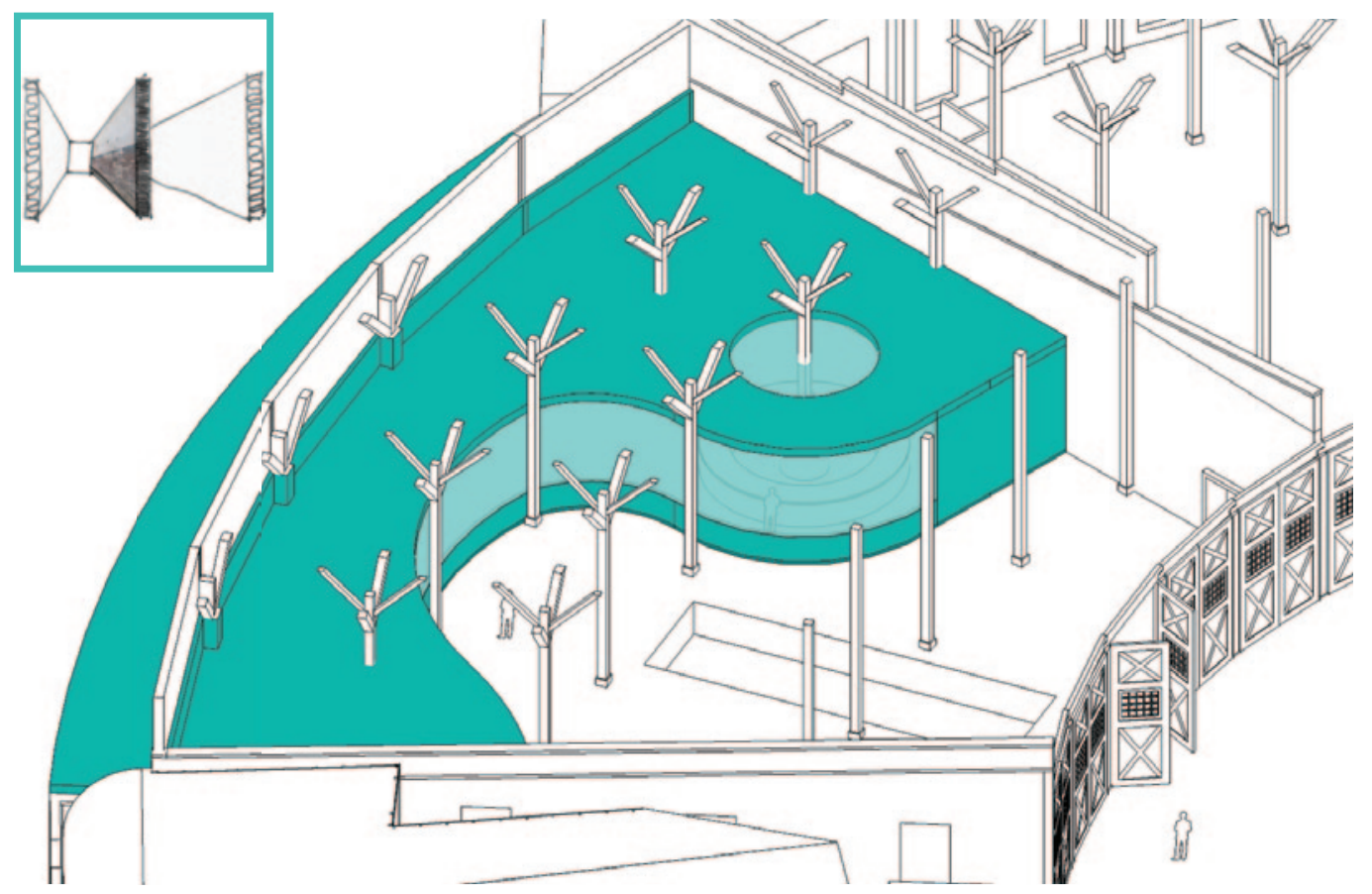

Figure 3.2 Café design B. 


\section{APPENDIX \\ SITE \\ DOCUMENTATION HANNA, ALBERTA}

Figure 4.1:

Collapsing stalls 11-15,

by C. Moorhouse, 2011.

Figure 4.2:

Collapsing stalls 11-15,

by C. Moorhouse, 2011.

Figure 4.3:

Demolished stalls 11-15,

by C. Moorhouse, 2013.
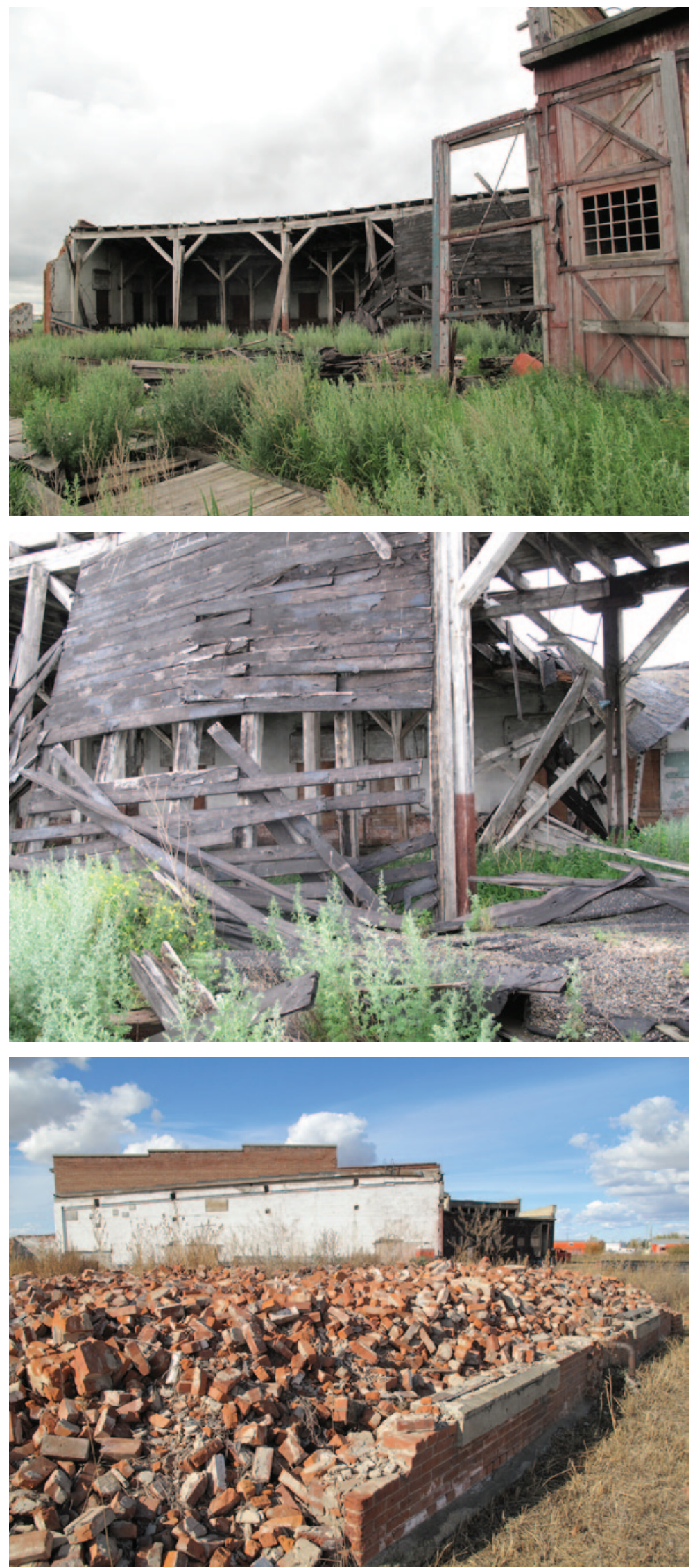
Figure 4.4:

Demolished stall 11,

by C. Moorhouse, 2013.

Figure 4.5:

Roundhouse doors,

by C. Moorhouse, 2013.

Figure 4.6:

Roundhouse interior, stall 1,

by C. Moorhouse, 2013.
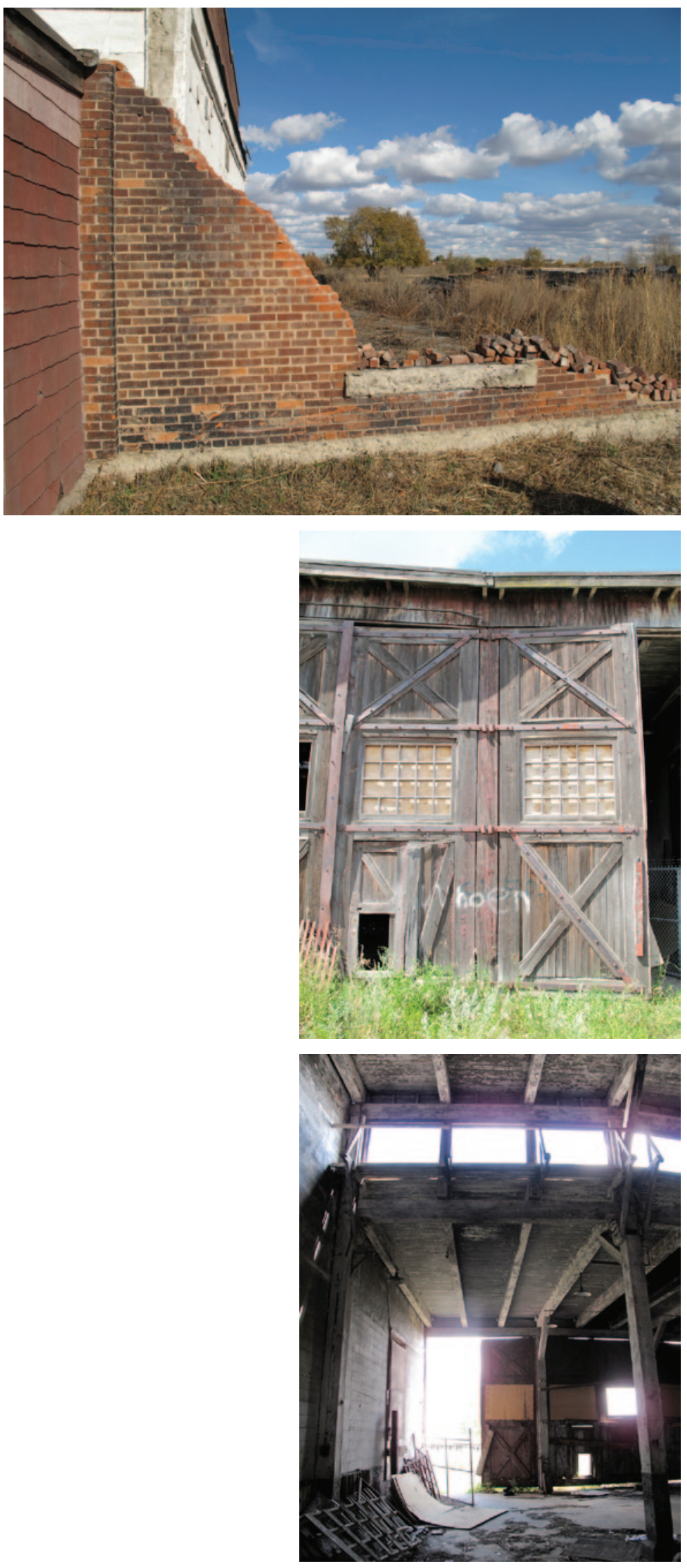
Figure 4.7:

Interior stalls 1-5,

by C. Moorhouse, 2013.

Figure 4.8:

Back of stall 5, connection to machine shop,

by C. Moorhouse, 2013.

Figure 4.9:

Cattle scale, stall 7 ,

by C. Moorhouse, 2013.
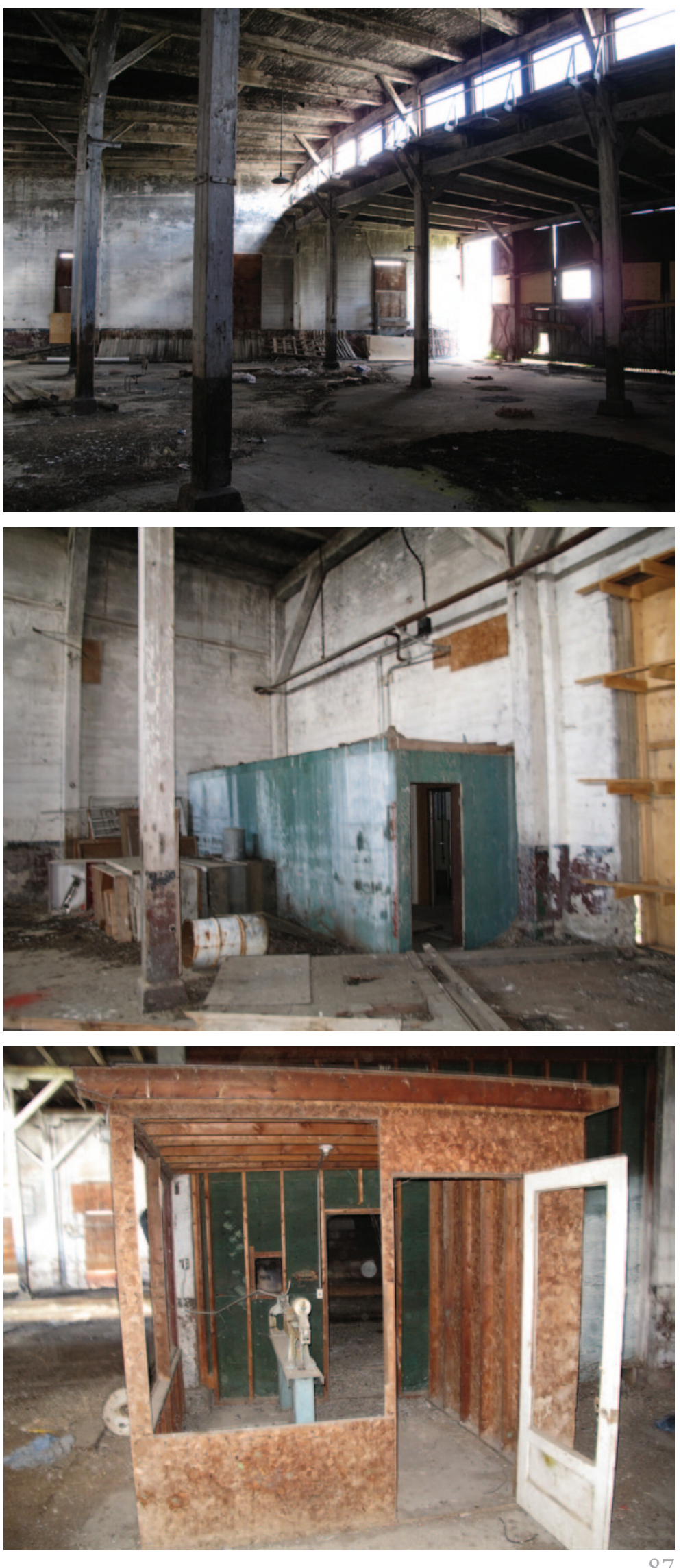
Figure 4.10:

Interior of cattle arena, stalls 6-7, by C. Moorhouse, 2013.

Figure 4.11

Cattle arena (stalls 6-7) wall viewed from stalls 8-10

by C. Moorhouse, 2013
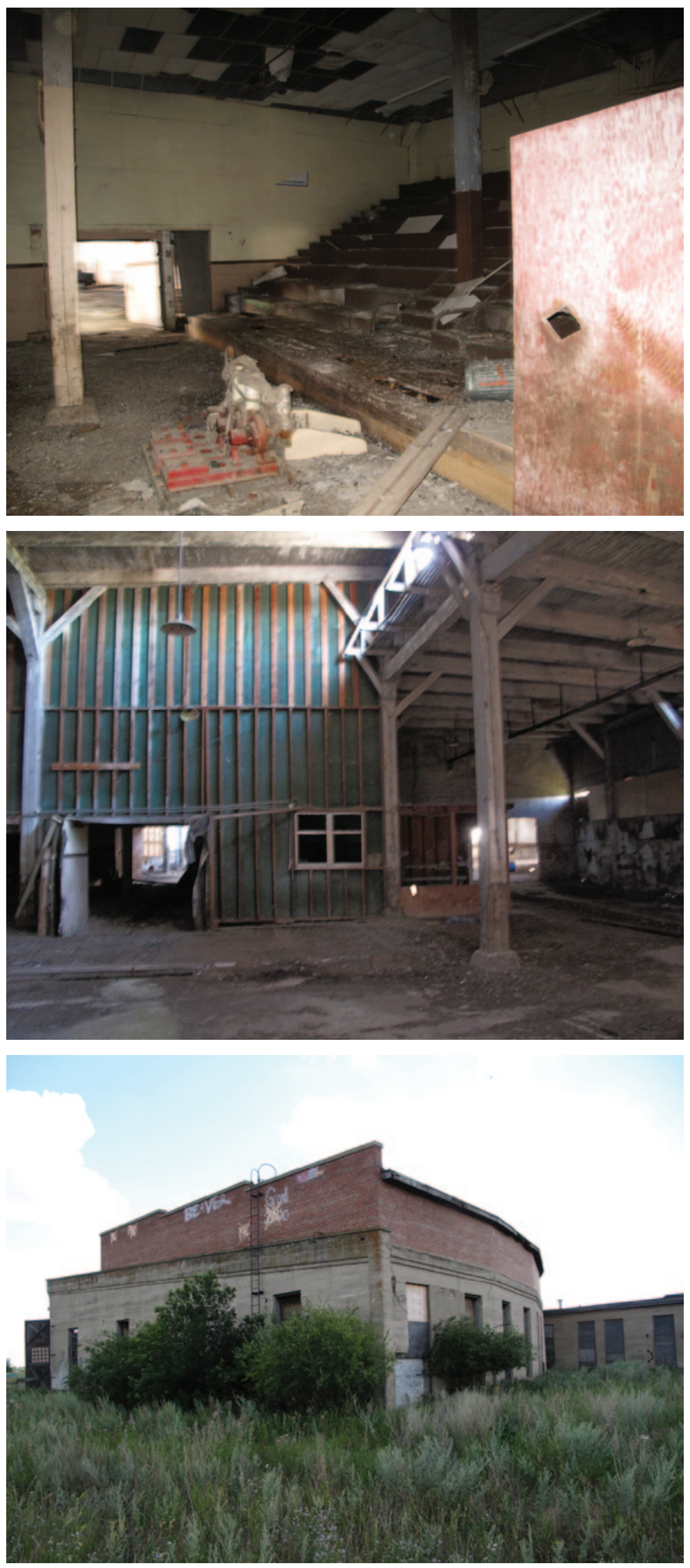

Exterior North facade, by C. Moorhouse, 2013. 
Figure 4.13:

Roundhouse viewed from other side of tracks,

by C. Moorhouse, 2013.

Figure 4.14:

Turntable,

by C. Moorhouse, 2013.

Figure 4.15

Roundhouse from Palliser Trail, by C. Moorhouse, 2013.

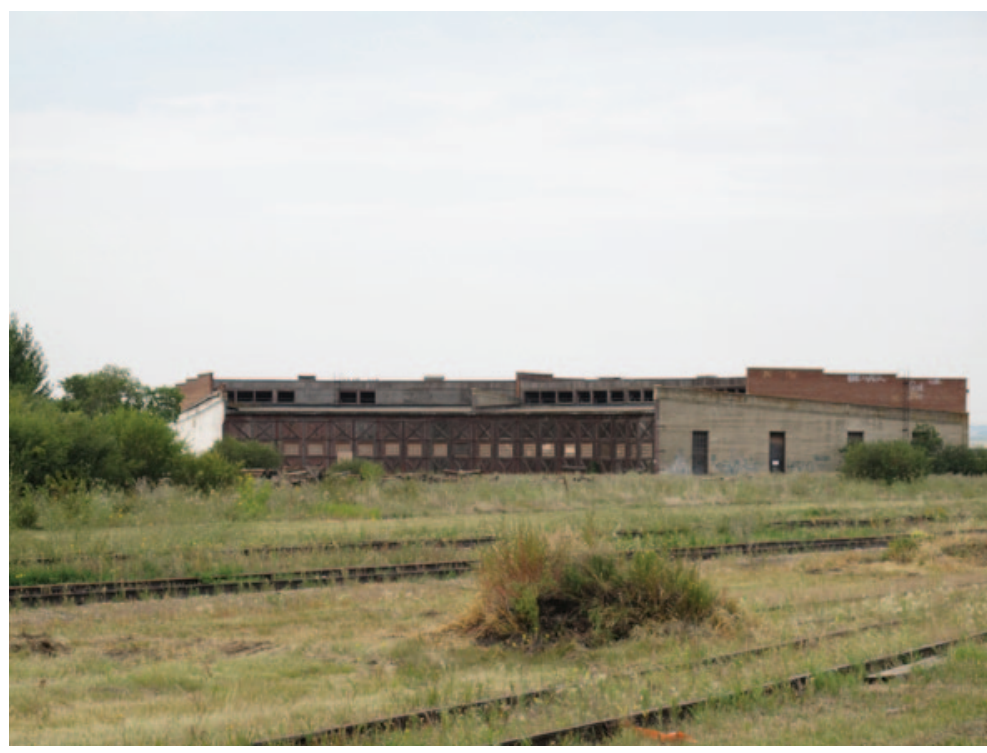

$\frac{2}{2}$
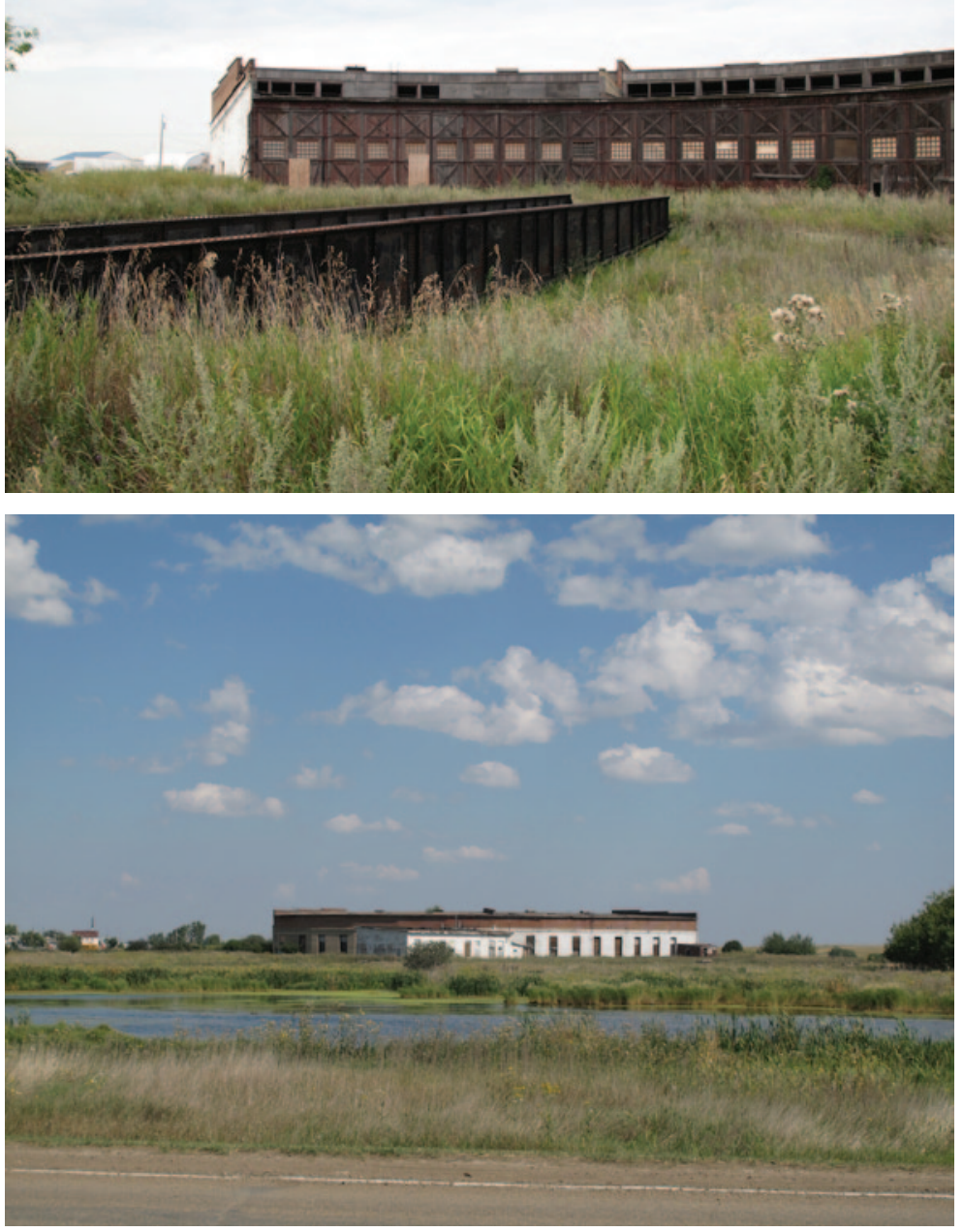
Figure 4.16:

Clerestory detail,

by C. Moorhouse, 2013.

Figure 4.17:

Column detail at door,

by C. Moorhouse, 2013.

Figure 4.18:

Under the risers in the cattle arena, by C. Moorhouse, 2013.
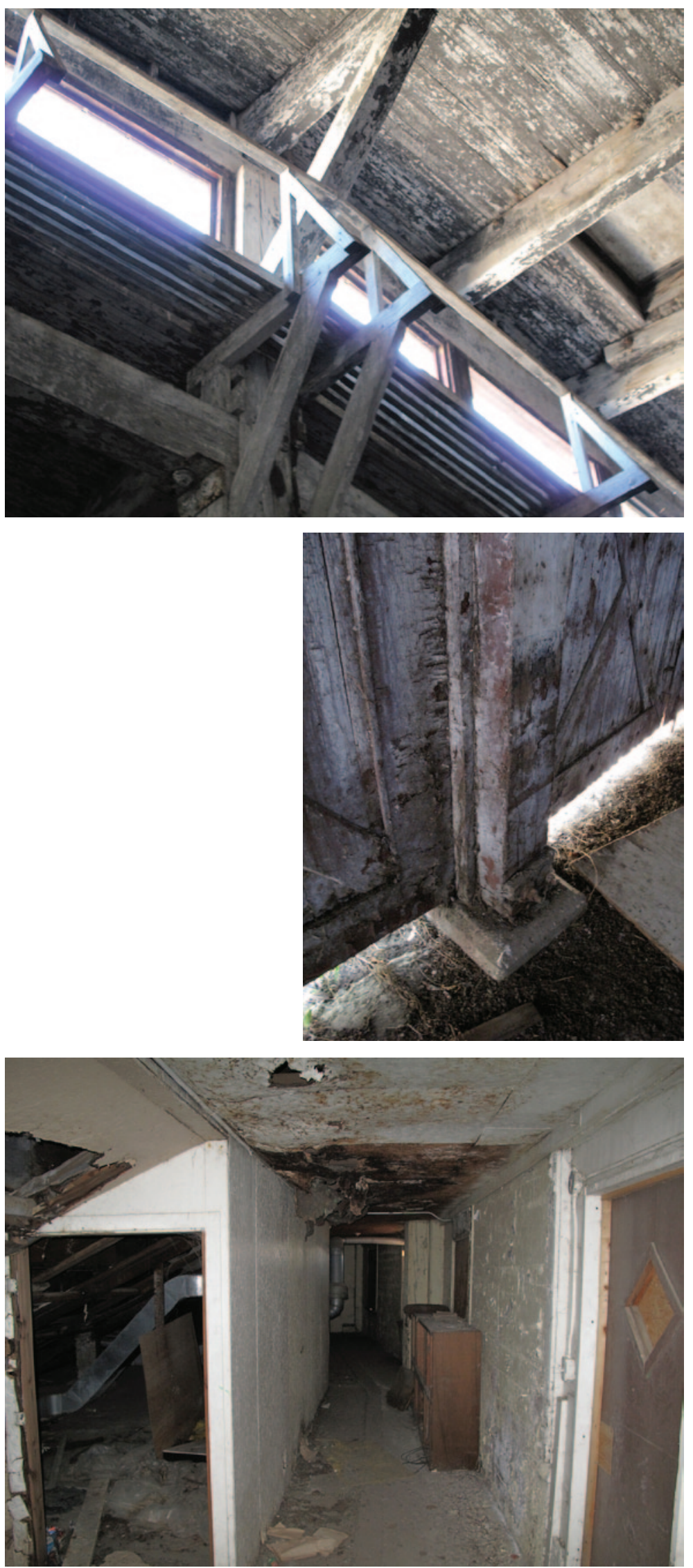
Figure 4.19:

Kitchen in machine shop, by C. Moorhouse, 2013.

Figure 4.20:

Washroom in machine shop, by C. Moorhouse, 2013.

Figure 4.21:

Washroom in machine shop, by C. Moorhouse, 2013.
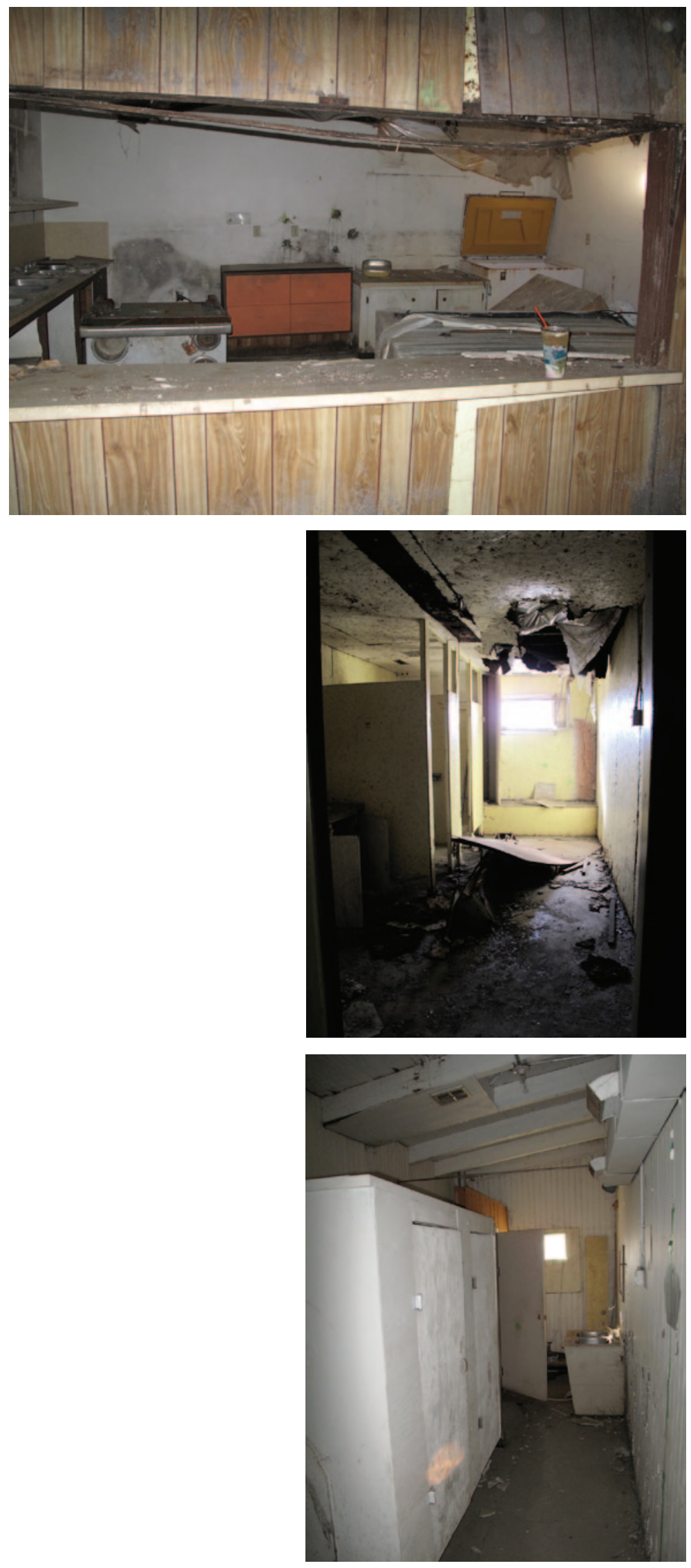
Figure 4.22:

Machine shop South-West side, by C. Moorhouse, 2013.

Figure 4.23:

Water tower foundations, by C. Moorhouse, 2013.

Figure 4.24:

Under the turntable,

by C. Moorhouse, 2013.
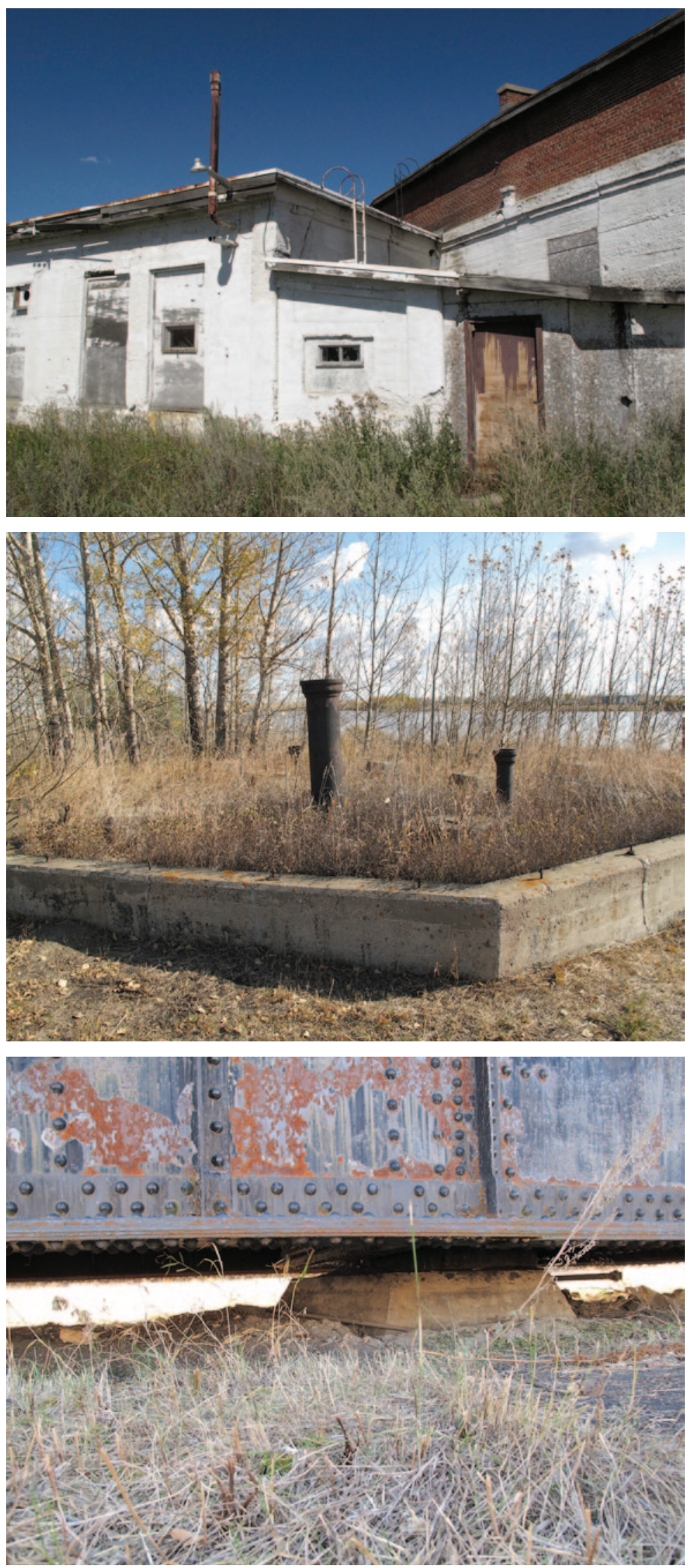
Figure 4.25:

Under the turntable,

by C. Moorhouse, 2013.

Figure 4.26:

Under the turntable,

by C. Moorhouse, 2013.

Figure 4.27:

Under the turntable,

by C. Moorhouse, 2013.
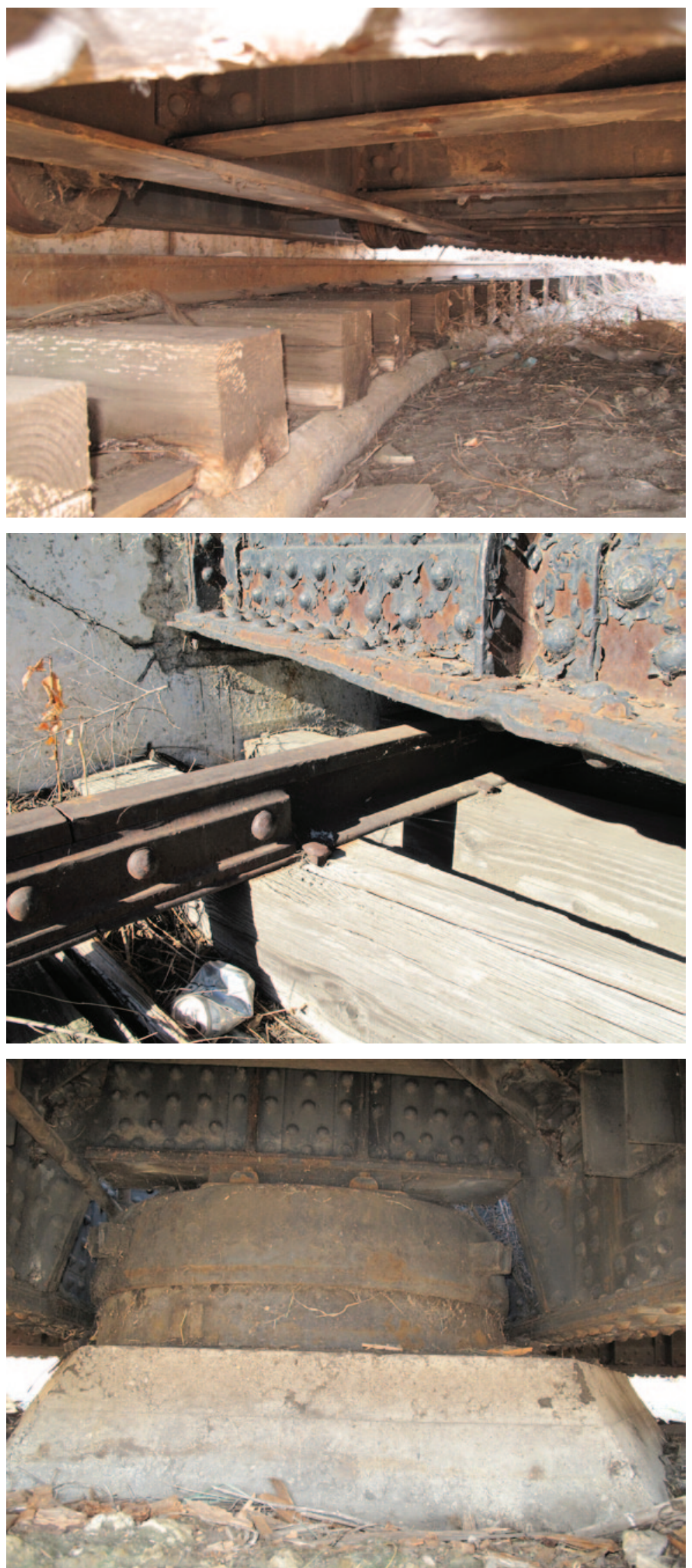


\section{APPENDIX}

HANNA CONTEXT $\&$ LANDSCAPE

Figure 5.1:

Heading East on Highway 9

Approaching Hanna,

by C. Moorhouse, 2014.

Figure 5.2:

Heading North on Palliser Trail

Roundhouse turn off on right,

by C. Moorhouse, 2014.

Figure 5.3:

Approaching Roundhouse from the West,

by C. Moorhouse, 2014.
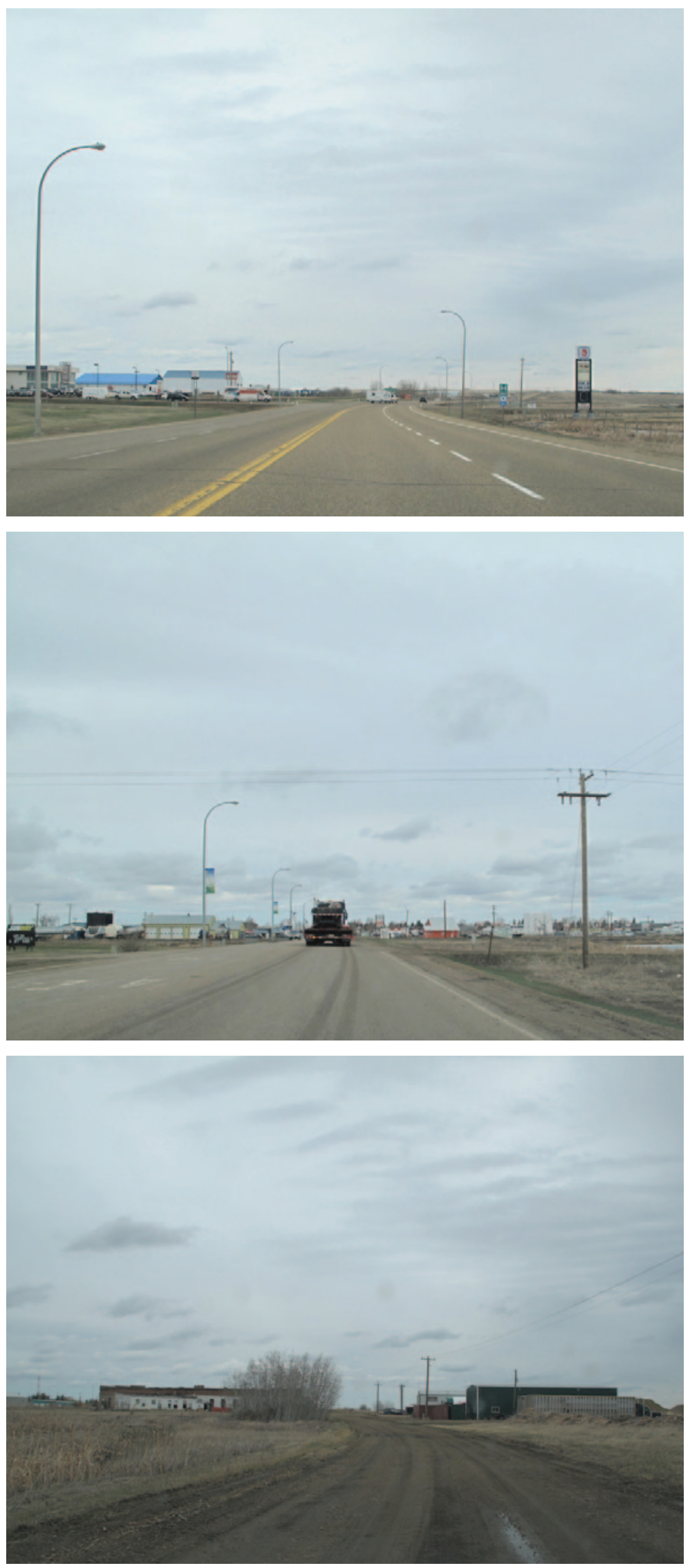
Figure 5.4:

View towards Visitor's Info Centre from Railyards,

by C. Moorhouse, 2014.

Figure 5.5:

Looking East along the Rail Lines, by C. Moorhouse, 2014.

Figure 5.6:

Looking North Across Rail Lines, by C. Moorhouse, 2014.
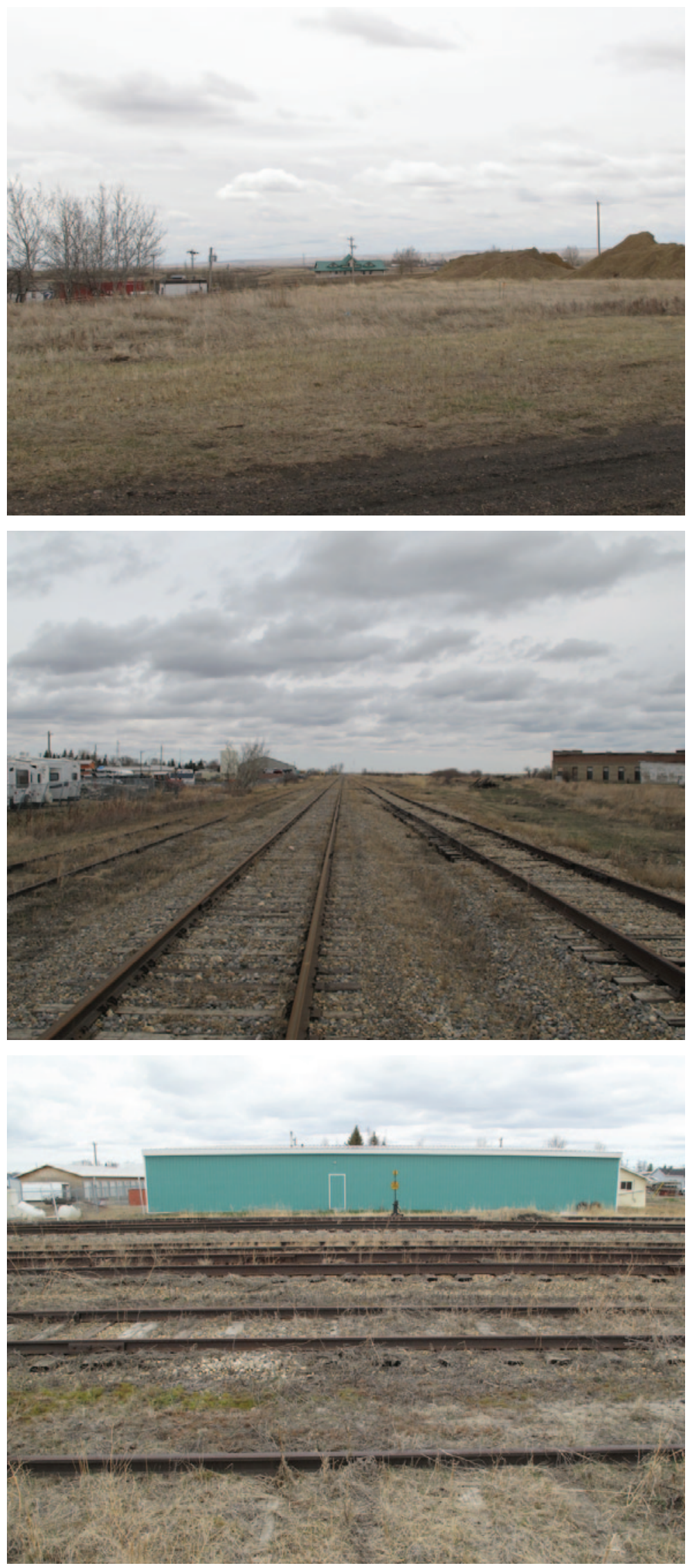
Figure 5.7:

Main Street, Hanna,

by C. Moorhouse, 2014.

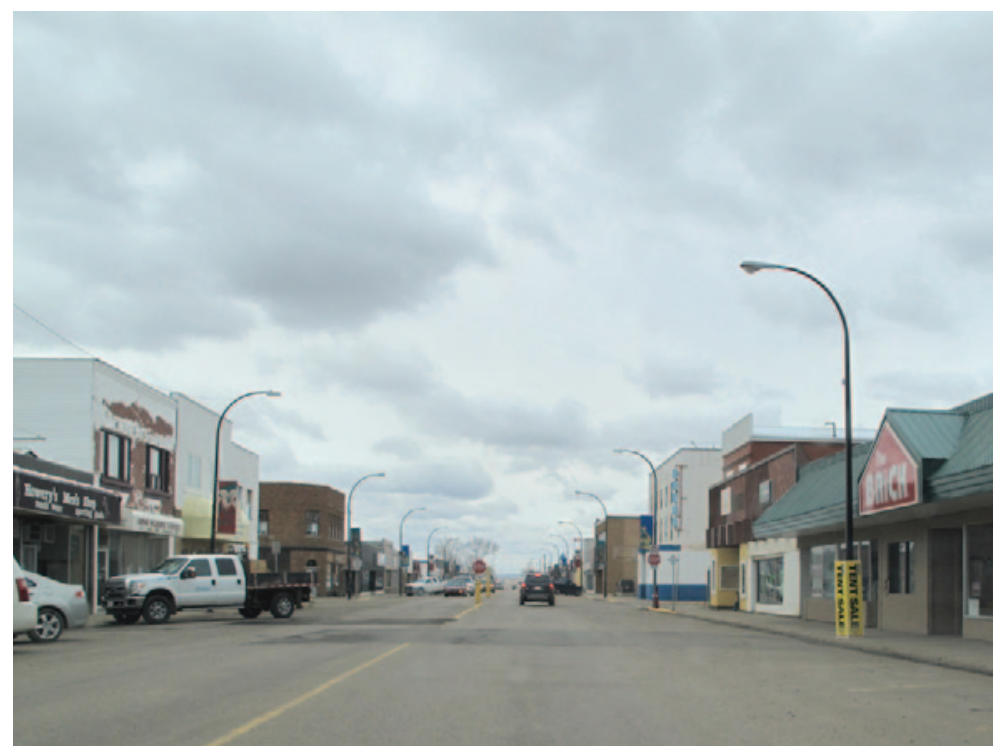

Figures 5.8 \& 5.9 :

Visitor's Information Centre off of

Highway 9,

by C. Moorhouse, 2014.
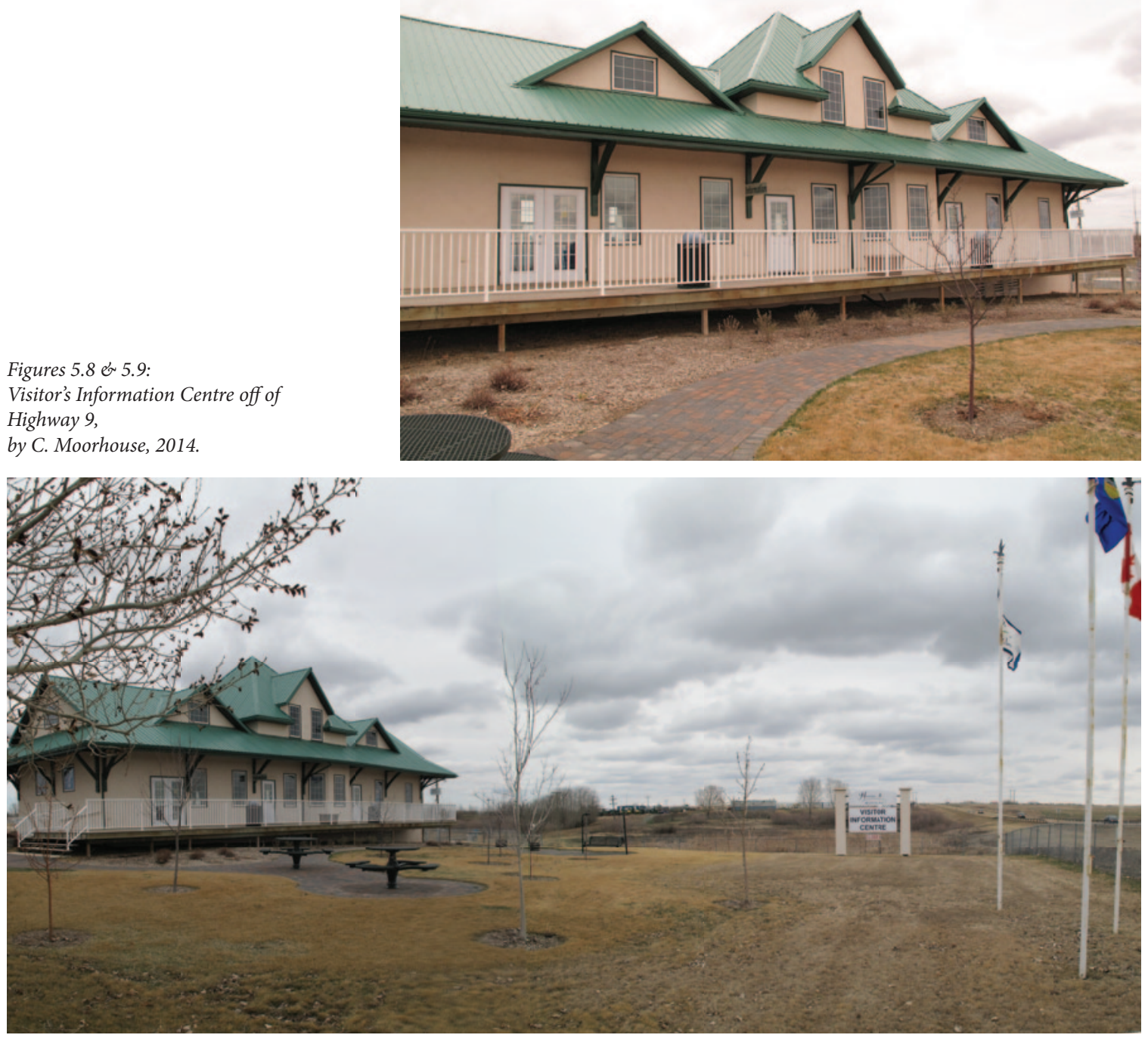
Figure 5.10:

Pioneer Village,

by C. Moorhouse, 2014.

Figures 5.11:

Pioneer Village,

by C. Moorhouse, 2014.
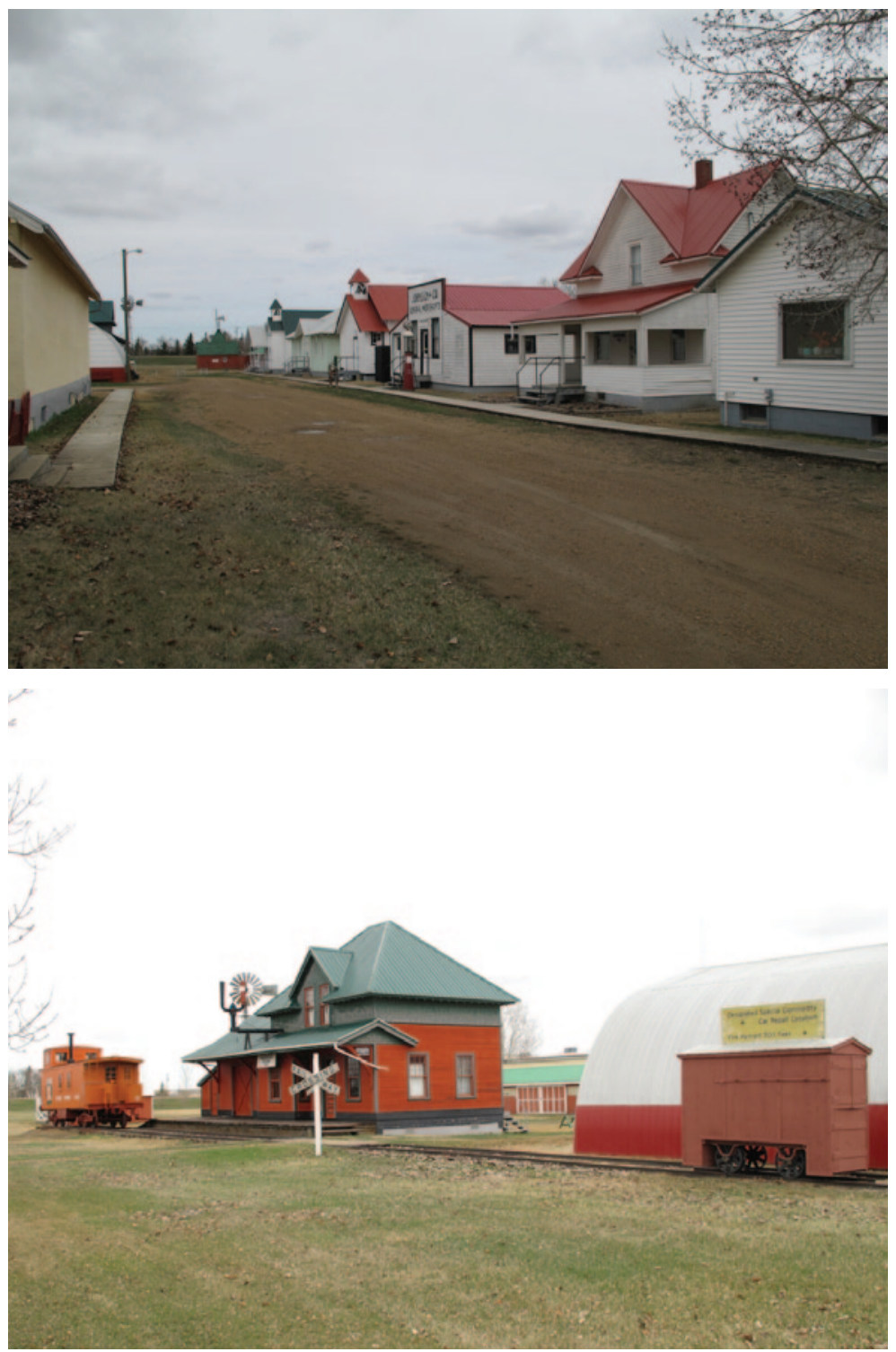


\section{APPENDIX \\ PHOTOS - \\ BIG VALLEY, ALBERTA}

Figure 6.1:

Footings, Big Valley, Alberta by C. Moorhouse, 2013.

Figure 6.2:

Pits, Big Valley, Alberta by C. Moorhouse, 2013.

Figure 6.3:

Machine shop, Big Valley, Alberta by C. Moorhouse, 2013.
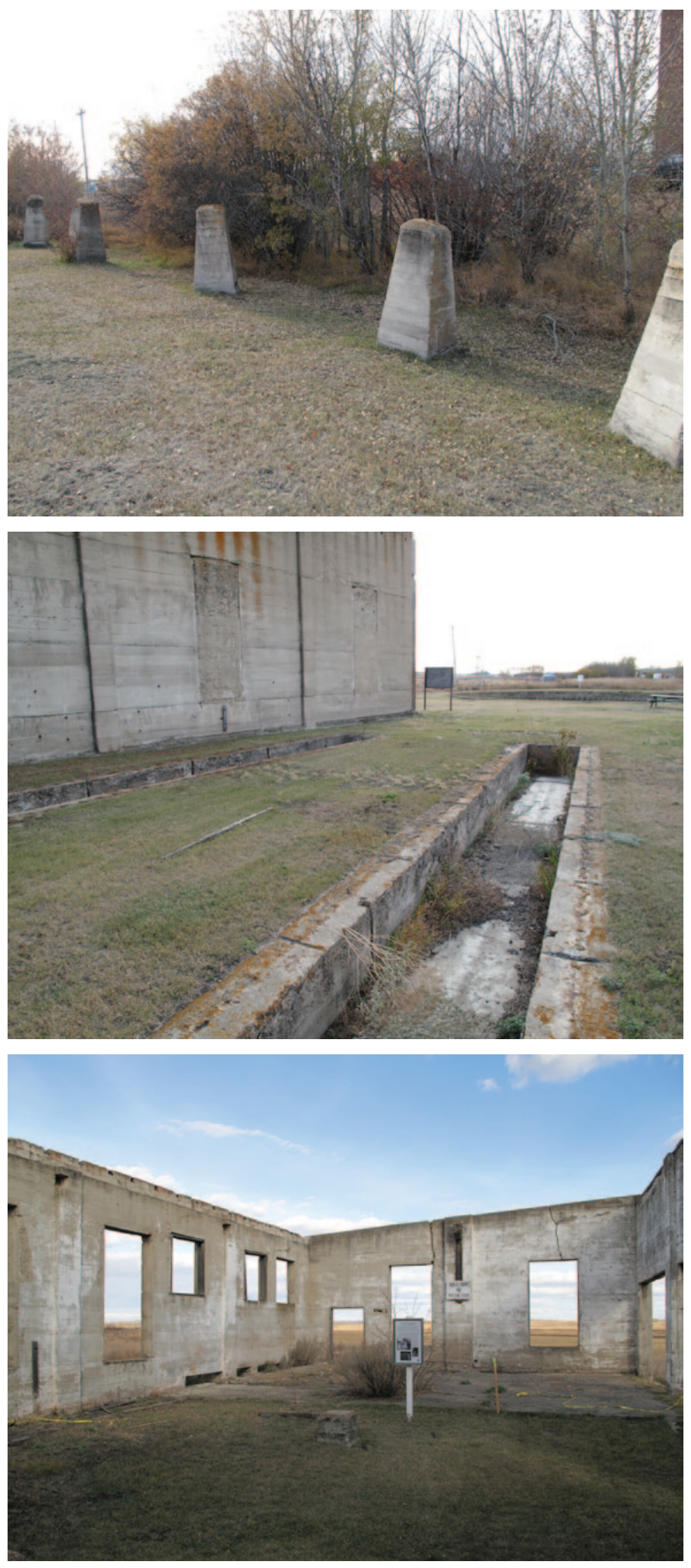
Figure 6.4:

Machine shop, Big Valley, Alberta by C. Moorhouse, 2013.

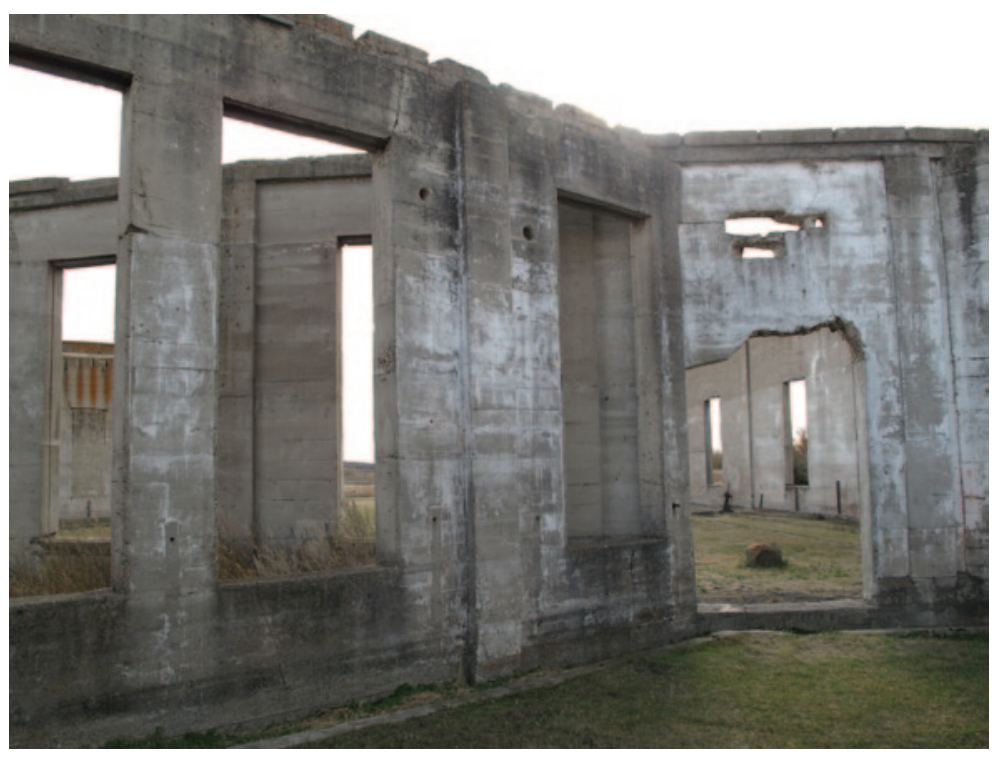

Figure 6.5:

Roundhouse, Big Valley, Alberta by C. Moorhouse, 2013.

Figure 6.6:

Roundhouse, Big Valley, Alberta by C. Moorhouse, 2013.
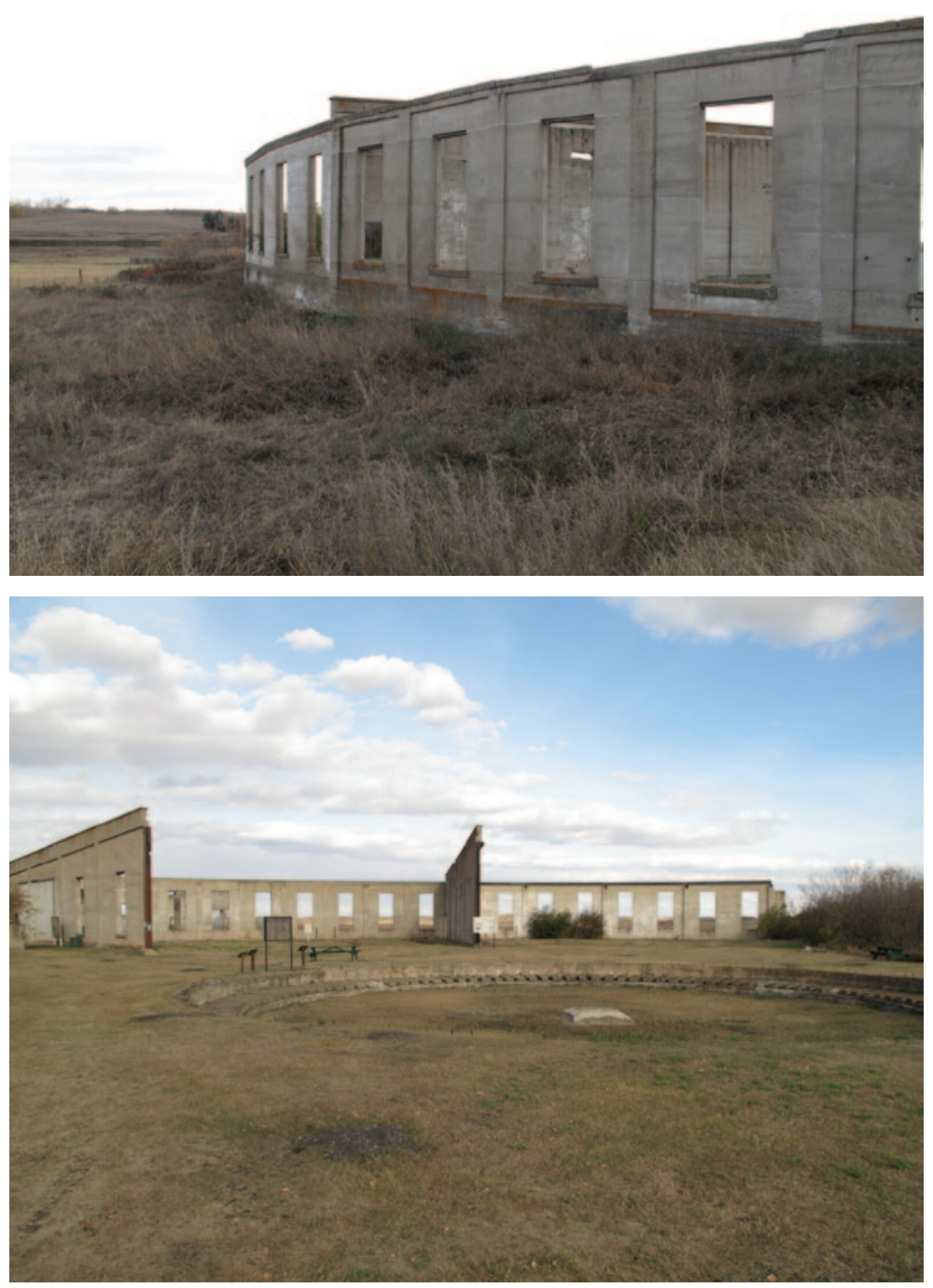
Figure 6.7:

Machine shop plan, Big Valley, Alberta by C. Moorhouse, 2013.

Figure 6.8:

Roundhouse plan, Big Valley, Alberta by C. Moorhouse, 2013.

Figure 6.9:

CNoR Map, Big Valley, Alberta

by C. Moorhouse, 2013.
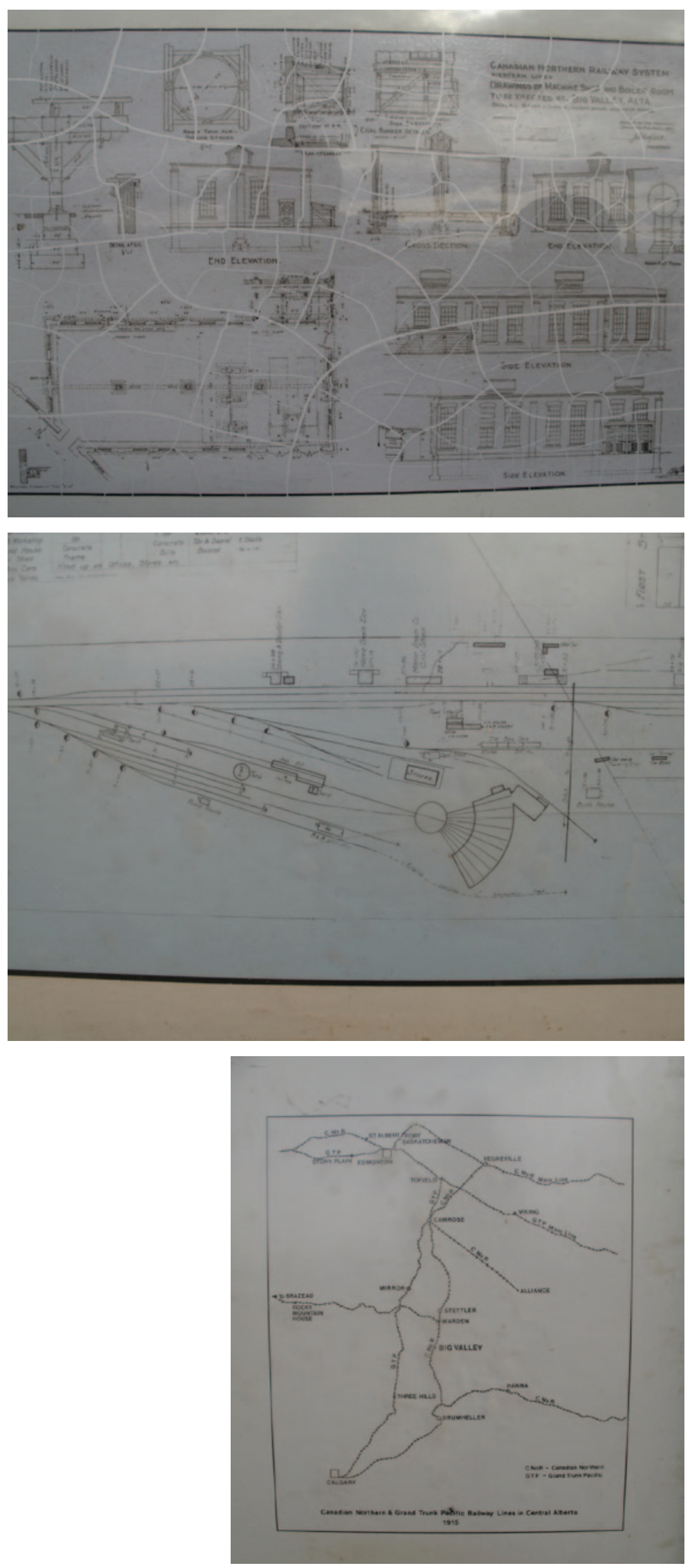


\section{LIST OF FIGURES}

\section{PART I}

PAGE 10

Figure 1.1 - "John Soane Museum, London, 1824"Photograph, 2006. <http:// en.wikipedia.org/wiki/File:Soane_Museum_1.jpg> (accessed 15/01/2014).

Figure 1.2 - Sandby, Thomas. "Westminster Hall and New Palace Yard" Painting. $<$ http://www.parliament.uk/worksofart/artwork/unknown/westminster-hall-andnew-palace-yard--about-1795-/2271> (accessed 15/01/2014).

\section{PAGE 13}

Figure 1.3 - Roosevelt Park Master Plan, Detroit, by Urban Detail \& Tadd Heidgerken. <http://photos.mlive.com/detroit/2011/08/roosevelt-parkurbandetail-01j.html $>$ (accessed 15/01/2014).

Figure 1.4 - Michigan Central Station ruin in Detroit. <http://en.wikipedia. org/wiki/File:Michigan_Central_Train_Station_Exterior_2010.jpg > (accessed 15/01/2014).

Figure 1.5 - Ara Pacis, Rome <http://www.apartamentosenroma.es/wp-content/ uploads/2012/11/1295449501-rh1624-623.jpg > (accessed 7/02/2014).

Figure 1.6 - Ara Pacis Museum, Rome by Richard Meier <http:/farm9.staticflickr. com/8296/7996418510_fc24c98f06_h.jpg> (accessed 7/02/2014).

\section{PAGE 16}

Figure 1.7 - Archbishopric Museum in Hamar, Norway by Sverre Fehn. <http:// shakespeareintitchfield.weebly.com/archbishopric-museum-of-hamar--sverrefehn.html> (accessed 22/01/2014).

Figure 1.8 - Castelvecchio, Verona, Italy by Carlo Scarpa. <http://farm2.staticflickr. com/1218/880369528_f08e4daf3f_o.jpg> (accessed 22/01/2014).

Figure 1.9 - 9/11 Memorial \& Museum, New York City, by Michael Arad. $<$ http://www.fodors.com/wire/New-York-City-9-11-Memorial-aerial-rendering. jpg $>$ (accessed 22/01/2014). 
Figure 1.10 - Tribute in Light, New York City.

$<$ http://upload.wikimedia.org/wikipedia/commons/thumb/6/6f/Tribute_ in_Light_-_11_September_2010_-_2.jpg/786px-Tribute_in_Light_-_11_ September_2010_-_2.jpg> (accessed 22/01/2014).

\section{PAGE 20}

Figure 1.11 - Kolumba Museum, Cologne, Germany by Peter Zumthor. $<$ http://www.building.co.uk/Pictures/web/a/u/p/Zumthor_Kolumba_Art_ Museum.jpg> (accessed 22/01/2014).

Figure 1.12 - St. Columba Church, pre bombing, Cologne, Germany. $<$ http://2.bp.blogspot.com/-mvjE75J8c7c/T5OLinW-AgI/AAAAAAAARLU/ zQWQ12yWEMM/s1600/st_kolumba_inside.jpg> (accessed 22/01/2014).

Figure 1.13 - Original elevated railway, New York City. $<$ http://www.thehighline.org/galleries/images/high-line-operation > (accessed $7 / 02 / 2014)$.

Figure 1.14 - The High Line, New York City by James Corner, Diller Scofidio + Renfro \& Piet Oudolf.

Baan, Iwan, 2009. <http://www.thehighline.org/galleries/images/high-line-parkphotos $>$ (accessed 7/02/2014).

\section{PAGE 22}

Figure 1.15 - Interior, of Notre Dame, Paris.

<http://iliketowastemytime.com/sites/default/files/top_10_things_to_do_while_ in_paris_notre_dame_de_paris6.jpg > (accessed 7/02/2014).

Figure 1.16 - Le Stryge gargoyle, Notre Dame, Paris.

Emil P. Albrecht, National Geographic Creative, 1910. <http://www.natgeocreative. com/comp/IR18/326/1319815.jpg > (accessed 7/02/2014).

\section{PART II}

\section{PAGE 27}

Figure 2.1 - Aerial view of the Hanna, Alberta railway yards and shop - looking East, 1981.

Bohi, Charles W. "Along these lines", Canadian Northern Society. Photograph, 1981. 


\section{PAGE 29}

Figure 2.2 - The Hanna Roundhouse location.

Map made by C. Moorhouse using Google Earth.

\section{PAGE 30}

Figure 2.3 - The Hanna Roundhouse contextual map.

Map made by C. Moorhouse using Google Earth.

\section{PAGE 31}

Figure 2.4 - The Hanna Roundhouse site plan.

Map made by C. Moorhouse using Google Earth.

\section{PAGE 33}

Figure 2.5 - 1920's photo of CNR railyards, courtesy of the Town of Hanna.

\section{PAGE 34}

Figure 2.6 - The Hanna Roundhouse Timeline \& Morphology by C. Moorhouse using the following photographs:

- 1920's photo of CNR railyards, courtesy of the Town of Hanna.

- Concrete walls and cattle pens, Photograph. Hilderman Feir Witty \& Associates. Hanna Historical Roundhouse and Village: feasibility study and concept design. Edmonton: Hilderman Feir Witty, 1981: 73-74.

- Photograph by C. Hutton 2009.

\section{PAGE 35}

Figure 2.7 - The Hanna Roundhouse by C. Hutton, 2009.

Figure 2.8 - The Hanna Roundhouse by C. Moorhouse, 2011.

Figure 2.9 - The Hanna Roundhouse by C. Moorhouse, 2013.

\section{PAGE 36}

Figure 2.10 - The Hanna Roundhouse Characteristics Collage. Made by C. Moorhouse. 
PAGE 39

Figure 2.11 - Existing Plan \& Section by C. Moorhouse.

\section{PAGE 41}

Figure 2.12 - Design methodology by C. Moorhouse.

\section{PAGE 42}

Figure P1 - Paratextual sketch by C. Moorhouse.

Figure M1 - Metatextual sketch by C. Moorhouse.

Figure H1 - Hypertextual sketch by C. Moorhouse.

Figure A1 - Architextual sketch by C. Moorhouse.

\section{PAGE 44}

Figure E2 - Existing photo of north wall of roundhouse by C. Moorhouse.

Figure P2a - Paratextual sketch by C. Moorhouse.

Figure P2b - Paratextual sketch by C. Moorhouse.

Figure P2c - Paratextual sketch by C. Moorhouse.

Figure H2 - Hypertextual sketch by C. Moorhouse.

\section{PAGE 46}

Figure E3 - Existing photo of north window of roundhouse by C. Moorhouse.

Figure P3 - Paratextual sketch by C. Moorhouse.

Figure M3 - Metatextual sketch by C. Moorhouse.

Figure H3 - Hypertextual sketch by C. Moorhouse.

\section{PAGE 48}

Figure 2.13 - Museum Plan by C. Moorhouse. 
PAGE 49

Figure 2.14 - Museum Summer Render by C. Moorhouse.

PAGE 50

Figure 2.15 - Museum Winter Render by C. Moorhouse.

PAGE 52

Figure M4 - Metatextual sketch by C. Moorhouse.

Figure P4a - Paratextual sketch by C. Moorhouse.

PAGE 53

Figure P4b - Paratextual sketch by C. Moorhouse.

Figure P4c - Paratextual sketch by C. Moorhouse.

Figure P4d - Paratextual sketch by C. Moorhouse.

PAGE 54

Figure 2.16 - Pathway detail by C. Moorhouse.

PAGE 55

Figure 2.17 - Café section by C. Moorhouse.

PAGE 56

Figure E5 - Existing pit condition by C. Moorhouse.

Figure P5 - Paratextual illustration by C. Moorhouse.

Figure M5 - Metatextual illustration by C. Moorhouse.

Figure H5 - Hypertextual illustration by C. Moorhouse.

PAGE 58

Figure 2.18 - Café (stalls 6-10) plan by C. Moorhouse. 
PAGE 59

Figure 2.19 - Café (stalls 6-10) Summer Render by C. Moorhouse.

PAGE 60

Figure 2.20 - Café (stalls 6-10) Winter Render by C. Moorhouse.

PAGE 62

Figure 2.21 - Hypertextual theatre form studies by C. Moorhouse.

Figure 2.22 - Metatextual theatre form studies by C. Moorhouse.

\section{PAGE 63}

Figure 2.23 - Theatre form by C. Moorhouse.

\section{PAGE 65}

Figure 2.24 - Roundhouse South Wall by C. Moorhouse.

\section{PAGE 66}

Figure 2.25- Theatre plan by C. Moorhouse.

\section{PAGE 67}

Figure 2.26 - Theatre Lobby Render by C. Moorhouse.

\section{PAGE 68}

Figure 2.27 - Theatre Section by C. Moorhouse.

\section{PAGE 69}

Figure 2.28 - Design Plan with Site by C. Moorhouse.

\section{PAGE 71}

Figure 2.29 - Site plan with parking and design by C. Moorhouse. 


\section{PAGE 72}

Figure 2.30 - Site ruins and features by C. Moorhouse.

- All photos by C. Moorhouse except image $7 \& 10$.

- Photo 7 by S. Beaudoin, 2013

- Photo 10 from <http://www.hanna.ca/Visitors/WhattoDo/MuralsMonuments. aspx $>$ (accessed 30/02/2014).

\section{PAGE 73}

Figure 2.31 - View from the Proposed Parking Towards the Roundhouse, by C. Moorhouse, 2014.

Figure 2.32 - View from the Proposed Parking Towards the CN Reservoir, by C. Moorhouse, 2013.

\section{PAGE 74}

Figure E6 - Original rail condition by C. Moorhouse.

Figure M6 - Metatextual illustration by C. Moorhouse.

\section{PAGE 75}

Figure P6 - Paratextual illustration by C. Moorhouse.

\section{PAGE 76}

Figure 2.33 - View from Turntable towards the Theatre by C. Moorhouse.

\section{PAGE 78}

Figure I7 - Intertextual photos by C. Moorhouse.

Figure P7 - Paratextual photo from <http://chuknum.com/2011/12/23/ architecture-small-scandinavian-island-house/> (accessed 03/03/2014).

Figure M7 - Metatextual photos by C. Moorhouse.

Figure H7A - Hypertextual photo from <http://pangaeacreations.com/decorative painting\#Close http://pangaeacreations.com/decorative_painting\#Close> (accessed 03/03/2014). 
Figure H7B - Hypertextual photo from <http://www.alucobond.com/home.html> (accessed 01/02/2014).

Figure A7 - Architextual photos by C. Moorhouse.

\section{PAGE 80}

Figure 2.34 - Brick gabion wall photo from <http://www.dreamstime.com/royaltyfree-stock-photography-gabion-retaining-wall-image18985117> (accessed 03/03/2014).

Figure 2.35 - Red stained wood photo by C. Moorhouse.

Figure 2.36 - Concrete chiseled detail photo by C. Moorhouse.

\section{APPENDICES}

\section{PAGE 84}

Figure 3.1 - Café design A by C. Moorhouse.

Figure 3.2 - Café design B by C. Moorhouse.

\section{PAGE 85}

Figure 4.1 - Collapsing stalls 11-15 by C. Moorhouse, 2011.

Figure 4.2 - Collapsing stalls 11-15 by C. Moorhouse, 2011.

Figure 4.3 - Demolished stalls 11-15 by C. Moorhouse, 2013.

\section{PAGE 86}

Figure 4.4 - Demolished stall 11 by C. Moorhouse, 2013.

Figure 4.5 - Roundhouse doors by C. Moorhouse, 2013.

Figure 4.6 - Roundhouse interior, stall 1 by C. Moorhouse, 2013.

\section{PAGE 87}

Figure 4.7 - Interior stalls 1-5 by C. Moorhouse, 2013. 
Figure 4.8 - Back of stall 5, connection to machine shop by C. Moorhouse, 2013.

Figure 4.9 - Cattle scale, stall 7 by C. Moorhouse, 2013.

\section{PAGE 88}

Figure 4.10 - Interior of cattle arena, stalls 6-7 by C. Moorhouse, 2013.

Figure 4.11 - Cattle arena (stalls 6-7) wall viewed from stalls 8-10 by C. Moorhouse, 2013.

Figure 4.12 - Exterior North facade by C. Moorhouse, 2013.

\section{PAGE 89}

Figure 4.13 - Roundhouse viewed from other side of tracks by C. Moorhouse, 2013.

Figure 4.14 - Turntable by C. Moorhouse, 2013.

Figure 4.15 - Roundhouse from Palliser Trail by C. Moorhouse, 2013.

\section{PAGE 90}

Figure 4.16 - Clerestory detail by C. Moorhouse, 2013.

Figure 4.17 - Column detail at door by C. Moorhouse, 2013.

Figure 4.18 - Under the risers in the cattle arena by C. Moorhouse, 2013.

\section{PAGE 91}

Figure 4.19 - Kitchen in machine shop by C. Moorhouse, 2013.

Figure 4.20 - Washroom in machine shop by C. Moorhouse, 2013.

Figure 4.21 - Washroom in machine shop by C. Moorhouse, 2013.

\section{PAGE 92}

Figure 4.22 - Machine shop South-West side by C. Moorhouse, 2013. 
Figure 4.23 - Water tower foundations by C. Moorhouse, 2013.

Figure 4.24 - Under the turntable by C. Moorhouse, 2013.

\section{PAGE 93}

Figure 4.25 - Under the turntable by C. Moorhouse, 2013.

Figure 4.26 - Under the turntable by C. Moorhouse, 2013.

Figure 4.27 - Under the turntable by C. Moorhouse, 2013.

\section{PAGE 94}

Figure 5.1 - Heading East on Highway 9 Approaching Hanna by C. Moorhouse, 2014.

Figure 5.2 - Heading North on Palliser Trail, Roundhouse turn off on right, by C. Moorhouse, 2014.

Figure 5.3 - Approaching Roundhouse from the West by C. Moorhouse, 2014.

\section{PAGE 95}

Figure 5.4 - View towards Visitor's Info Centre from Railyards by C. Moorhouse, 2014.

Figure 5.5 - Looking East along the Rail Lines by C. Moorhouse, 2014.

Figure 5.6 - Looking North Across Rail Lines by C. Moorhouse, 2014.

\section{PAGE 96}

Figure 5.7 - Main Street Hanna by C. Moorhouse, 2014.

Figure 5.8 - Visitor's Info Centre off of Highway 9 by C. Moorhouse, 2014.

Figure 5.9 - Visitor's Info Centre off of Highway 9 by C. Moorhouse, 2014.

\section{PAGE 97}

Figure 5.10 - Pioneer Village by C. Moorhouse, 2014.

Figure 5.11 - Pioneer Village by C. Moorhouse, 2014. 


\section{PAGE 98}

Figure 6.1 - Footings, Big Valley, Alberta by C. Moorhouse, 2013.

Figure 6.2 - Pits, Big Valley, Alberta by C. Moorhouse, 2013.

Figure 6.3 - Machine shop, Big Valley, Alberta by C. Moorhouse, 2013.

\section{PAGE 99}

Figure 6.4 - Machine shop, Big Valley, Alberta by C. Moorhouse, 2013.

Figure 6.5 - Roundhouse, Big Valley, Alberta by C. Moorhouse, 2013.

Figure 6.6 - Roundhouse, Big Valley, Alberta by C. Moorhouse, 2013.

\section{PAGE 100}

Figure 6.7 - Machine shop plan, Big Valley, Alberta by C. Moorhouse, 2013.

Figure 6.8 - Roundhouse plan, Big Valley, Alberta by C. Moorhouse, 2013.

Figure 6.9 - CNoR Map, Big Valley, Alberta by C. Moorhouse, 2013. 


\section{BIBLIOGRAPHY}

Alberti, Leon Battista. Ten books on architecture. London: A. Tiranti, 1965

"Ara Pacis Museum." Richard Meier \& Partners Architects LLP. http://www.richardmeier. com/www/\#/projects/architecture/location/europe-a-m/italy/1/277/0/ (accessed December 30, 2013).

Beaudoin, Sandra. Railroad history, Hanna, Alberta, 2012: a collection of railroad history of Hanna and surrounding communities along the Goose Lake line. Self-published, 2012.

Calvino, Italo. Invisible cities. [1st ed. New York: Harcourt Brace Jovanovich, 1974.

Camille, Michael. The gargoyles of Notre-Dame: medievalism and the monsters of modernity. Chicago: University of Chicago Press, 2009. Print.

"Construction." The High Line. http://www.thehighline.org/construction (accessed November 4, 2013).

Detroit Lives. DVD. Directed by Thalia Mavros. Docurama, 2010.

Dillon, Brian. Ruins. London: Whitechapel Gallery ;, 2011.

Dorin, Patrick C. The Canadian National Railways'story. Seattle: Superior Publishing Company, 1975.

Edensor, Tim. Industrial ruins spaces, aesthetics, and materiality. Oxford [U.K.: Berg, 2005.

Entry on Gérard Genette. The Johns Hopkins Guide to Literary Theory and Criticism, 2nd ed. Ed. Michael Groden, Martin Kreiswirth, and Imre Szeman. Baltimore: Johns Hopkins UP, 2004. 430-33.

Fein, Zach. "The Aesthetic of Decay: Space, Time, and Perception”. Thesis. University of Cincinnati. 2010-2011.

Frascari, Marco. “'“Semiotica ab Edendo", Taste in Architecture." Journal of Architectural Education (1984-) 40, no. 1 (1986).

Genette, Gérard. Palimpsests: literature in the second degree. Lincoln: University of Nebraska Press, 1997.

Genette, Gérard. Paratexts: thresholds of interpretation. Cambridge: Cambridge University Press, 1997. 
Goffi, Federica. Time matters: Invention and (Re)Imagination in Conservation: invention and (re)imagination in conservation: the unfinished drawing and building of St. Peters, the Vatican. Farnham: Ashgate, 2013.

Hilderman Feir Witty \& Associates. Hanna Historical Roundhouse and Village: feasibility study and concept design. Edmonton: Hilderman Feir Witty, 1981.

Hill, Jonathan. Weather architecture. London: Routledge, 2012.

"HLA.com." High Line Art. http://art.thehighline.org/project/spencerfinch/ (accessed March 27, 2014).

"James Corner Field Operations and Diller Scofidio + Renfro." The High Line. http:// www.thehighline.org/design/design-team-selection/field-operations-diller-scofidio-renfro (accessed November 4, 2013).

Jorgensen, Anna, and Richard Keenan. Urban wildscapes. London: Routledge, 2012.

Kristeva, Julia. Desire in language: a semiotic approach to literature and art. New York: Columbia University Press, 1980.

Lee, Pamela M., and Gordon Clark. Object to be destroyed the work of Gordon MattaClark. Cambridge, Mass.: MIT Press, 2000.

Machado, Rodolfo. Old Buildings as Palimpsest, in "Progressive Architecture", November, 1976.

Mah, Alice. Industrial ruination, community, and place: landscapes and legacies of urban decline. Toronto: University of Toronto Press, 2012.

Moore, Rowan. Why we build. London: Picador, 2012.

Olivier, Laurent. The dark abyss of time: archaeology and memory. Lanham, Md.: AltaMira Press, 2011.

Roth, Michael S., Claire L. Lyons, and Charles Merewether. Irresistible decay: ruins reclaimed. Los Angeles, CA: The Getty Research Institute for the History of Art and the Humanities, 1997.

Ruskin, John. The lamp of memory. London: Penguin, 2008.

Schulz, Christian, and Gennaro Postiglione. Sverre Fehn: works, projects, writings, 19491996. New York: Monacelli Press, 1997. 
Statistics Canada. 2011. 2011 Census Profile for Hanna, Alberta.

Town of Hanna $>\mid$ Visitors $>$ History $>$ A History of Hardship." Town of Hanna $>\mid$ Visitors > History $>$ A History of Hardship. http://www.hanna.ca/Visitors/History/ AHistoryofHardship.aspx (accessed December 12, 2013).

Trigg, Dylan. The aesthetics of decay: nothingness, nostalgia, and the absence of reason. New York: Peter Lang, 2006.

Trigg, Dylan. “The psychoanalysis of ruins.” 3:AM Magazine. http://www.3ammagazine. com/3am/the-psychoanalysis-of-ruins/ (accessed September 9, 2013).

Viollet-le-Duc, Eugène. The foundations of architecture: selections from the Dictionnaire raisonné. New York: G. Braziller, 1990.

Williams Engineering, Structural Evaluation, 2010. Courtesy of Sandra Beaudoin.

Woodward, Christopher. In ruins. New York: Pantheon Books, 2001. 